Portland State University

PDXScholar

\title{
Measuring the Performance of Transit Relative to Livability
}

\author{
Marc Schlossberg \\ University of Oregon \\ Jennifer Dill \\ Portland State University, jdill@pdx.edu \\ Liang Ma \\ Portland State University \\ Cody Meyer \\ University of Oregon
}

Follow this and additional works at: https://pdxscholar.library.pdx.edu/usp_fac

Part of the Transportation Commons, Urban Studies Commons, and the Urban Studies and Planning Commons

Let us know how access to this document benefits you.

\section{Citation Details}

Schlossberg, Mark, Jennifer Dill , Liang Ma, and Cody Meyer. Measuring the Performance of Transit Relative to Livability. OTREC-RR-13-04. Portland, OR: Transportation Research and Education Center (TREC), 2013. http://dx.doi.org/10.15760/trec.135

This Report is brought to you for free and open access. It has been accepted for inclusion in Urban Studies and Planning Faculty Publications and Presentations by an authorized administrator of PDXScholar. Please contact us if we can make this document more accessible: pdxscholar@pdx.edu. 


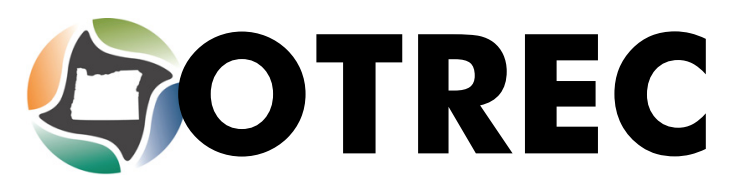

FINAL REPORT

\section{Measuring the Performance of Transit Relative to Livability}

OTREC-RR-13-04

March 2013 


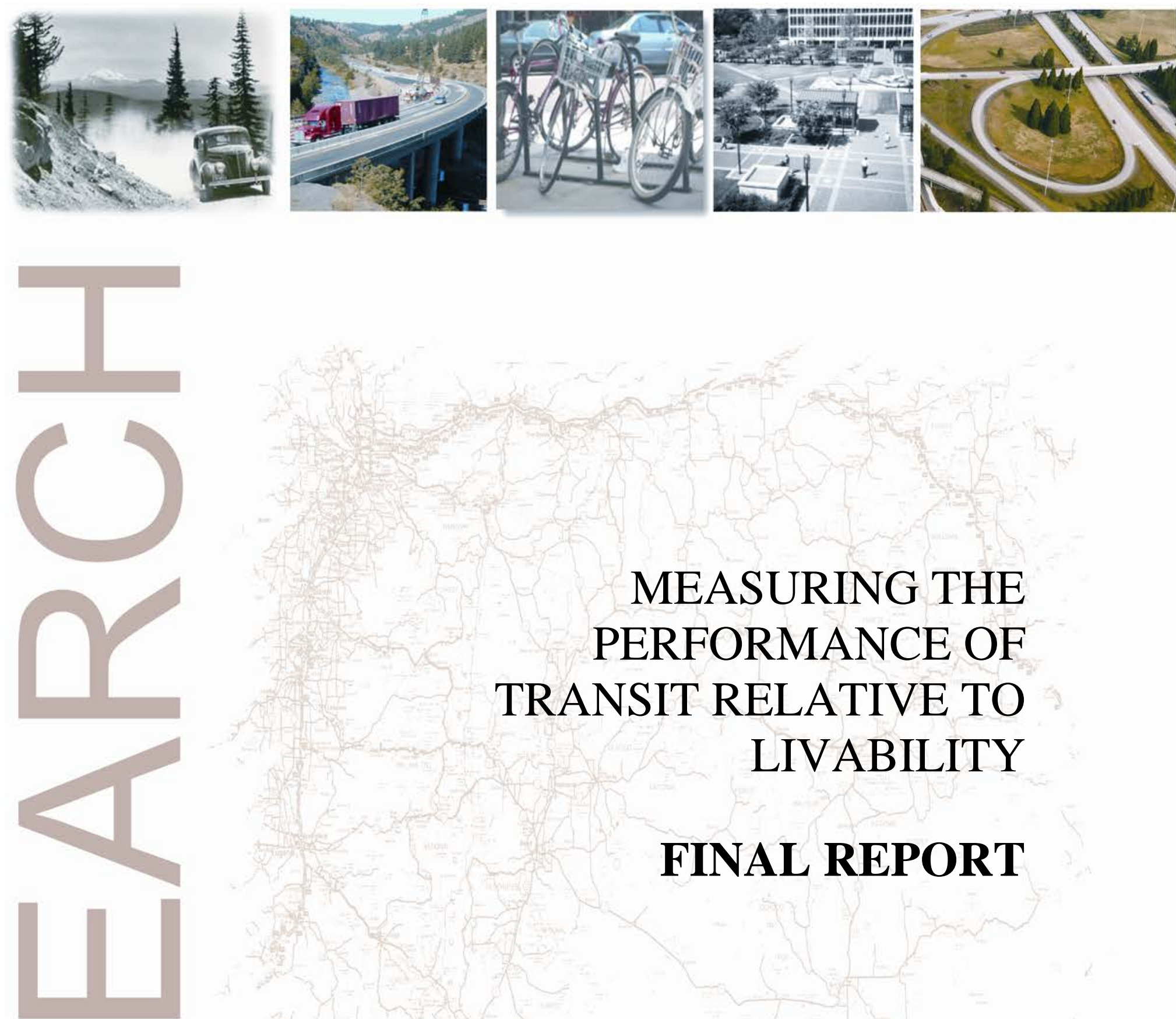

\section{MEASURING THE PERFORMANCE OF TRANSIT RELATIVE TO \\ LIVABILITY}

\section{FINAL REPORT}
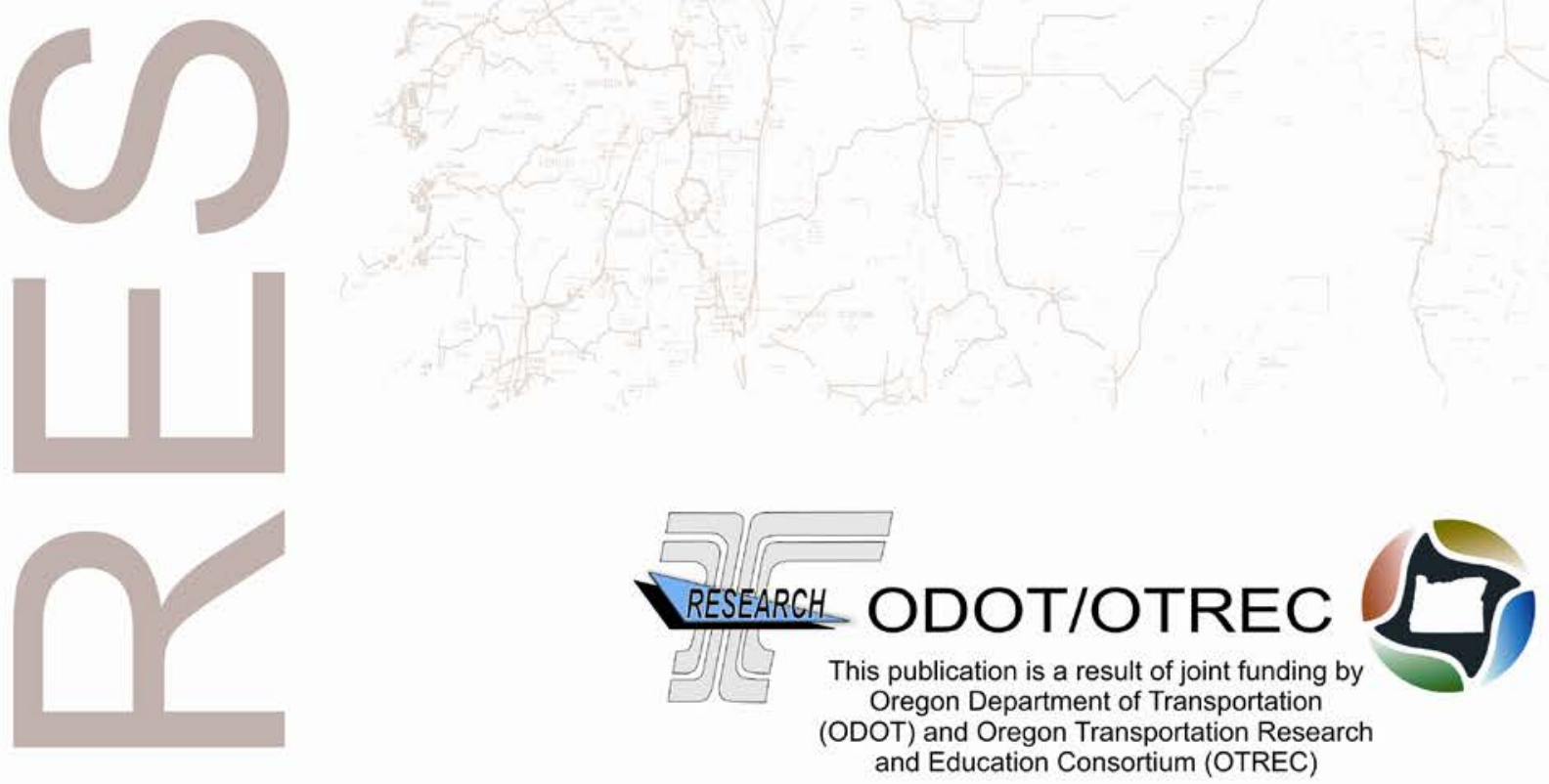



\title{
MEASURING THE PERFORMANCE OF TRANSIT RELATIVE TO LIVABILITY
}

\author{
Final Report \\ SPR 735 \\ OTREC-RR-13-04 \\ by \\ Marc Schlossberg, $\mathrm{PhD}$ \\ Cody Meyer \\ University of Oregon \\ Department of Planning, Public Policy \& Management \\ and \\ Jennifer Dill, Ph.D. \\ Liang Ma \\ Portland State University \\ Nohad A. Toulan School of Urban Studies \& Planning \\ for \\ Oregon Department of Transportation \\ Research Section \\ Salem OR 97301 \\ and \\ Oregon Transportation Research \\ and Education Consortium (OTREC) \\ Portland, OR 97207 \\ and \\ Federal Highway Administration \\ 400 Seventh Street, SW \\ Washington, DC 20590
}

March 2013 

Technical Report Documentation Page

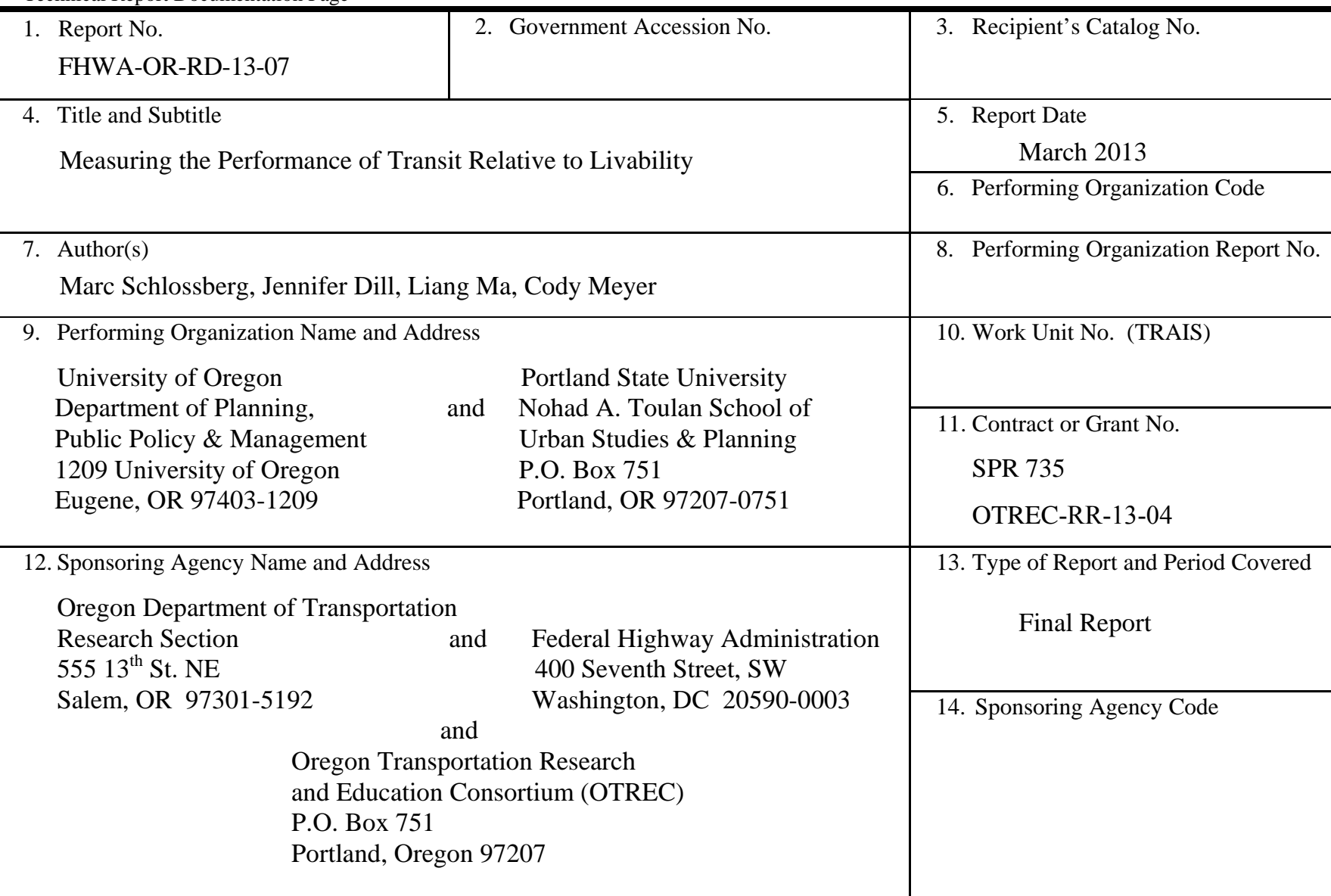

15. Supplementary Notes

16. Abstract

This project sought to understand the relationship between urban form, transit service characteristics, and ridership measured at the stop level. Most previous work in this area has looked at these issues separately, by either linking system performance (e.g. on-time performance, cost, etc.) to ridership or exploring the connection between urban form (e.g. density) and transit use. This project synthesized these disparate approaches. While transit service characteristics (e.g. frequency, travel time, etc.) are important to help individuals reach their desired destinations, most transit users are pedestrians at the beginning and end of any transit trip. Therefore, focusing on the walkable zone around each transit stop was also important.

17. Key Words

TRANSIT, LIVABILITY, URBAN FORM, RIDERSHIP, 18. Distribution Statement

Copies available from NTIS, and online at http://www.oregon.gov/ODOT/TD/TP_RES/

\begin{tabular}{l|l|c}
\hline $\begin{array}{l}\text { 19. Security Classification (of this report) } \\
\text { Unclassified }\end{array}$ & $\begin{array}{c}\text { 20. Security Classification (of this page) } \\
\text { Unclassified }\end{array}$ & $\begin{array}{c}\text { 21. No. of Pages } \\
120\end{array}$
\end{tabular}




\begin{tabular}{|c|c|c|c|c|c|c|c|c|c|}
\hline \multicolumn{10}{|c|}{ SI* (MODERN METRIC) CONVERSION FACTORS } \\
\hline \multicolumn{5}{|c|}{ APPROXIMATE CONVERSIONS TO SI UNITS } & \multicolumn{5}{|c|}{ APPROXIMATE CONVERSIONS FROM SI UNITS } \\
\hline Symbol & When You Know & Multiply By & To Find & Symbol & Symbol & When You Know & Multiply B & To Find & Symbol \\
\hline \multicolumn{5}{|c|}{ LENGTH } & \multicolumn{5}{|c|}{ LENGTH } \\
\hline in & inches & 25.4 & millimeters & $\mathrm{mm}$ & $\mathrm{mm}$ & millimeters & 0.039 & inches & in \\
\hline $\mathrm{ft}$ & feet & 0.305 & meters & $\mathrm{m}$ & $\mathrm{m}$ & meters & 3.28 & feet & $\mathrm{ft}$ \\
\hline yd & yards & 0.914 & meters & $\mathrm{m}$ & $\mathrm{m}$ & meters & 1.09 & yards & yd \\
\hline $\mathrm{mi}$ & miles & 1.61 & kilometers & $\mathrm{km}$ & $\mathrm{km}$ & kilometers & 0.621 & miles & mi \\
\hline \multicolumn{5}{|c|}{$\underline{\text { AREA }}$} & \multicolumn{5}{|c|}{$\underline{\text { AREA }}$} \\
\hline in $^{2}$ & square inches & 645.2 & millimeters squared & $\mathrm{mm}^{2}$ & $\mathrm{~mm}^{2}$ & millimeters squared & 0.0016 & square inches & in $^{2}$ \\
\hline $\mathrm{ft}^{2}$ & square feet & 0.093 & meters squared & $\mathrm{m}^{2}$ & $\mathrm{~m}^{2}$ & meters squared & 10.764 & square feet & $\mathrm{ft}^{2}$ \\
\hline $\mathrm{yd}^{2}$ & square yards & 0.836 & meters squared & $\mathrm{m}^{2}$ & $\mathrm{~m}^{2}$ & meters squared & 1.196 & square yards & $\mathrm{yd}^{2}$ \\
\hline ac & acres & 0.405 & hectares & ha & ha & hectares & 2.47 & acres & ac \\
\hline $\mathrm{mi}^{2}$ & square miles & 2.59 & kilometers squared & $\mathrm{km}^{2}$ & $\mathrm{~km}^{2}$ & kilometers squared & 0.386 & square miles & $\mathrm{mi}^{2}$ \\
\hline \multicolumn{5}{|c|}{ VOLUME } & \multicolumn{5}{|c|}{ VOLUME } \\
\hline $\mathrm{fl} \mathrm{oz}$ & fluid ounces & 29.57 & milliliters & $\mathrm{ml}$ & $\mathrm{ml}$ & milliliters & 0.034 & fluid ounces & $\mathrm{fl} \mathrm{oz}$ \\
\hline gal & gallons & 3.785 & liters & $\mathrm{L}$ & $\mathrm{L}$ & liters & 0.264 & gallons & gal \\
\hline $\mathrm{ft}^{3}$ & cubic feet & 0.028 & meters cubed & $\mathrm{m}^{3}$ & $\mathrm{~m}^{3}$ & meters cubed & 35.315 & cubic feet & $\mathrm{ft}^{3}$ \\
\hline $\mathrm{yd}^{3}$ & cubic yards & 0.765 & meters cubed & $\mathrm{m}^{3}$ & $\mathrm{~m}^{3}$ & meters cubed & 1.308 & cubic yards & $\mathrm{yd}^{3}$ \\
\hline \multicolumn{10}{|c|}{ NOTE: Volumes greater than $1000 \mathrm{~L}$ shall be shown in $\mathrm{m}^{3}$. } \\
\hline \multicolumn{5}{|c|}{ MASS } & \multicolumn{5}{|c|}{ MASS } \\
\hline $\mathrm{Oz}$ & ounces & 28.35 & grams & g & g & grams & 0.035 & ounces & $\mathrm{oz}$ \\
\hline $\mathrm{lb}$ & pounds & 0.454 & kilograms & $\mathrm{kg}$ & $\mathrm{kg}$ & kilograms & 2.205 & pounds & $\mathrm{lb}$ \\
\hline $\mathrm{T}$ & short tons (2000 lb) & 0.907 & megagrams & $\mathrm{Mg}$ & $\mathrm{Mg}$ & megagrams & 1.102 & short tons (2000 lb) & $\mathrm{T}$ \\
\hline \multicolumn{5}{|c|}{ TEMPERATURE (exact) } & \multicolumn{5}{|c|}{ TEMPERATURE (exact) } \\
\hline${ }^{\circ} \mathrm{F}$ & Fahrenheit & $(\mathrm{F}-32) / 1.8$ & Celsius & ${ }^{\circ} \mathrm{C}$ & ${ }^{\circ} \mathrm{C}$ & Celsius & $1.8 \mathrm{C}+32$ & Fahrenheit & ${ }^{\circ} \mathrm{F}$ \\
\hline
\end{tabular}




\section{ACKNOWLEDGEMENTS}

The authors wish to thank the staff at TriMet, Lane Transit District, and Rogue Valley Transit District for their assistance in providing data for this research

\section{DISCLAIMER}

This document is disseminated under the sponsorship of the Oregon Department of Transportation and the United States Department of Transportation in the interest of information exchange. The State of Oregon and the United States Government assume no liability of its contents or use thereof.

The contents of this report reflect the view of the authors who are solely responsible for the facts and accuracy of the material presented. The contents do not necessarily reflect the official views of the Oregon Department of Transportation or the United States Department of Transportation.

The State of Oregon and the United States Government do not endorse products of manufacturers. Trademarks or manufacturers' names appear herein only because they are considered essential to the object of this document.

This report does not constitute a standard, specification, or regulation. 


\section{TABLE OF CONTENTS}

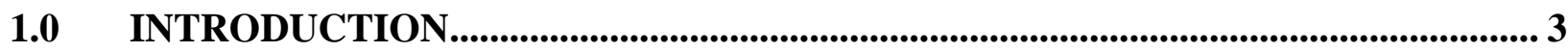

2.0 LITERATURE REVIEW .............................................................................................. 5

$2.1 \quad$ TRANSIT PERFORMANCE MEASURES....................................................................... 5

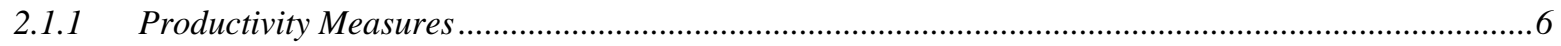

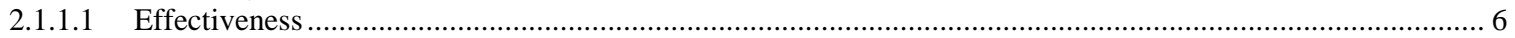

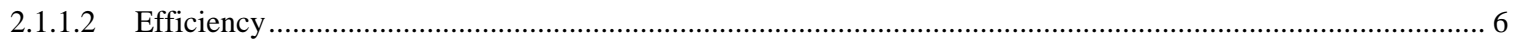

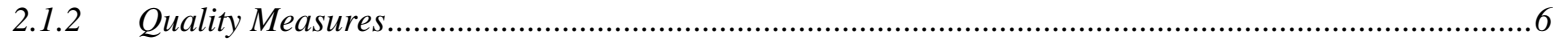

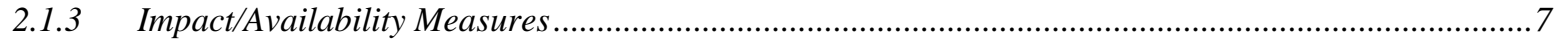

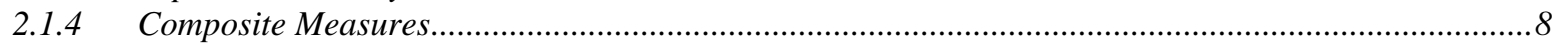

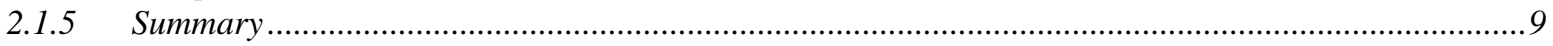

2.1.6 Differing Perspectives ........…………………………………………………………………12

2.2 RESEARCH LINKING URBAN FORM AND TRANSIT RIDERSHIP .................................... 12

2.2.1 Variables Included and their Effect on Ridership ……………………………………………......13

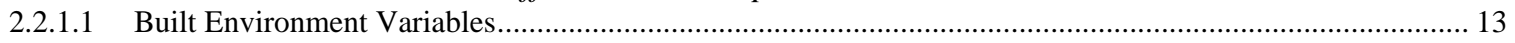

2.2.1.2 Level of Service Variables ............................................................................................................................... 18

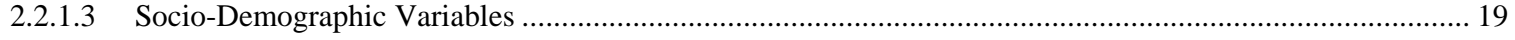

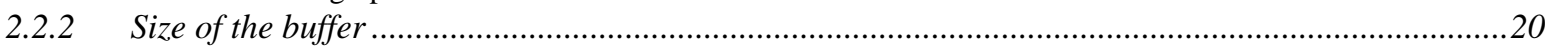

2.2.3 Measuring the dependent variable ………………………………………………………………...22

2.2.4 Form of the models ......................................................................................................................2

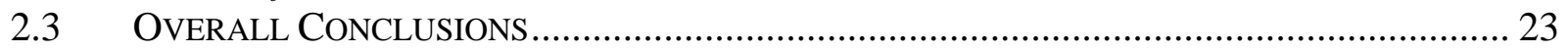

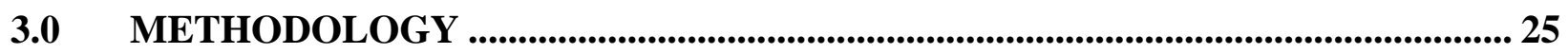

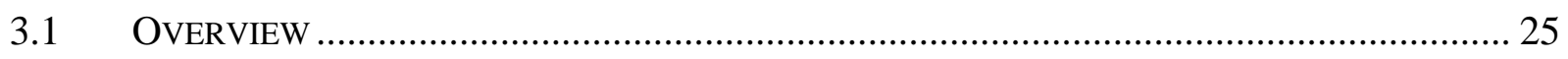

3.2 GIS AND REGRESSION ANALYSIS ......................................................................... 25

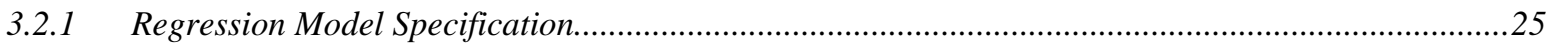

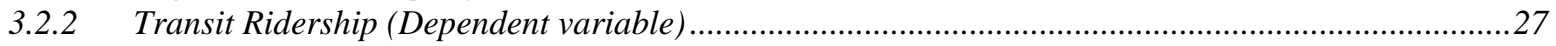

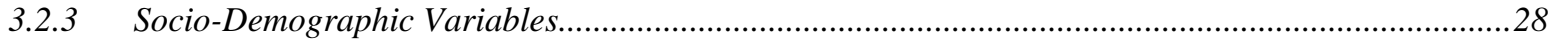

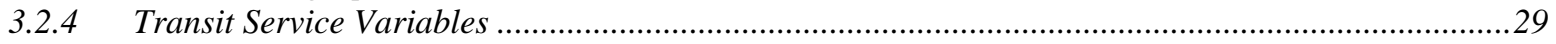

3.2.5 Transportation Infrastructure Variables ..........................................................................................29

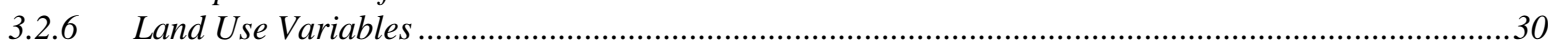

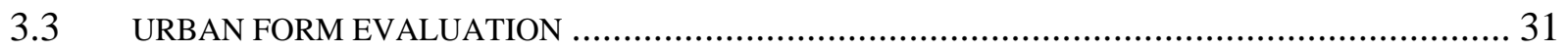

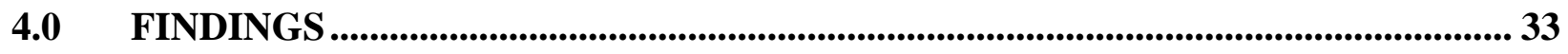

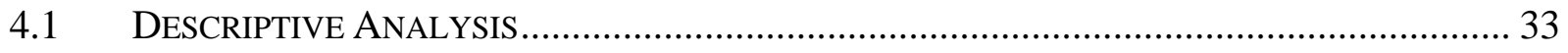

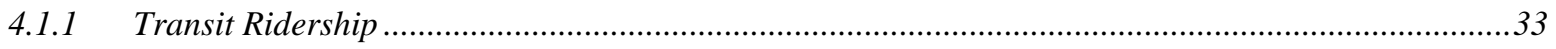

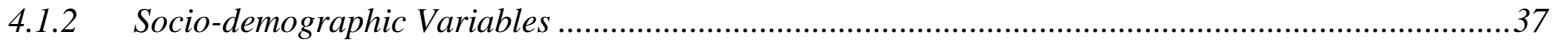

4.1.3 Transit Service Variables ......................................................................................................

4.1.4 Transportation Infrastructure Variables ……………………………………………………....40

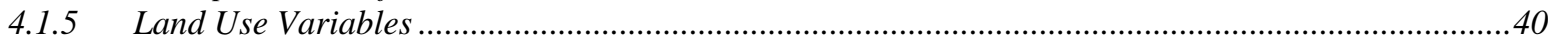

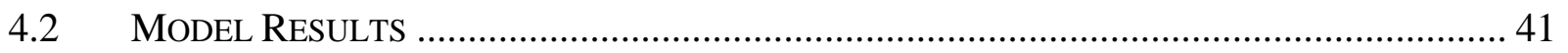

4.2.1 Socio-Demographic Variables...…………………………………………………………....4

4.2.2 Transit Service Variables ………………………………………………………………46

4.2.3 Transportation Infrastructure Variables .....................................................................................4

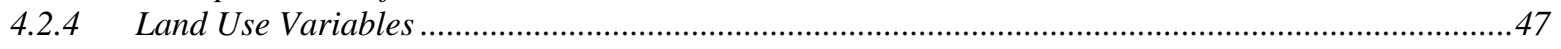

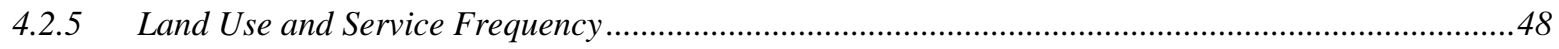

4.3 SUMMARY AND POTENTIAL APPLICATIONS OF REGRESSION ANALYSIS FINDINGS........... 51

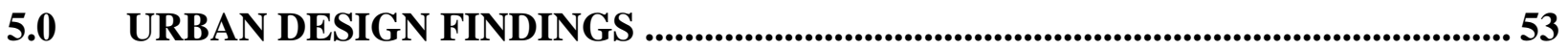


6.0 RECOMMENDATIONS............................................................................................. 59

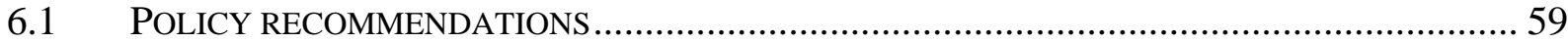

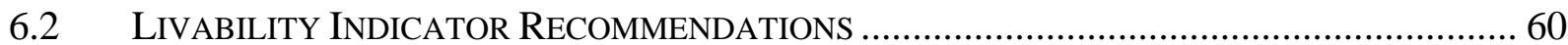

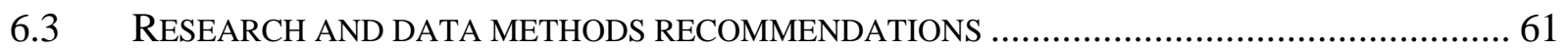

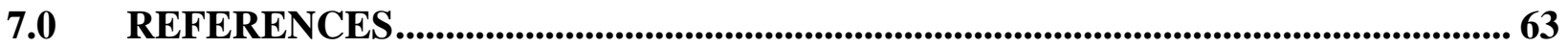

APPENDIX A: VARIABLE CALCULATIONS

APPENDIX B: GIS METHODS

\section{LIST OF TABLES}

Table 2.1: Summary of Transit Performance Measures ...................................................................................10

Table 2.2: Findings from Key Sources on Transit Performance .................................................................11

Table 2.3: Studies on Stop-Level Transit Ridership Model .........................................................................13

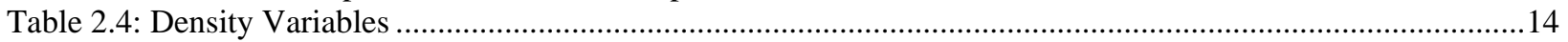

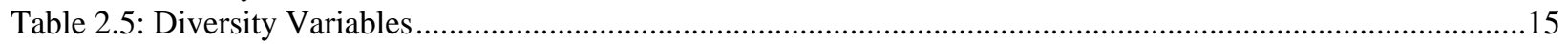

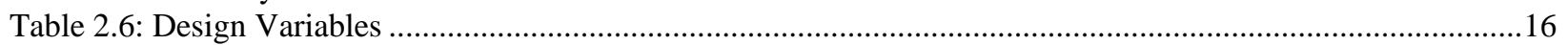

Table 2.7: Variables Measuring Transit Level of Service ............................................................................19

Table 2.8: Variables Measuring Socio-Demographic Characteristics of Transit Users ..........................................20

Table 2.9: Transit ridership analysis unit at the stop or station level ..............................................................22

Table 2.10: Dependent Variables in Transit Ridership Models.................................................................22

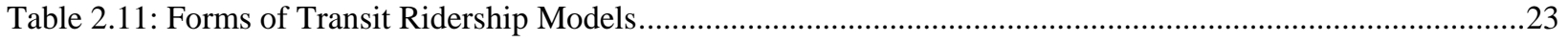

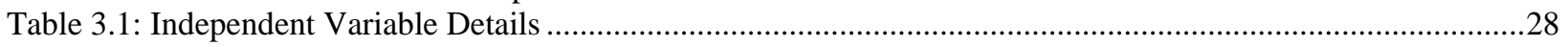

Table 4.1 Descriptive Statistics for the Variables in TriMet Model....................................................................35

Table 4.2 Descriptive Analysis for the Variables in Lane Transit Model ...............................................................36

Table 4.3 Descriptive analysis for the variables in Rogue Valley Model ............................................................37

Table 4.4: Contribution of Variables to Overall Model Explanatory Power..........................................................42

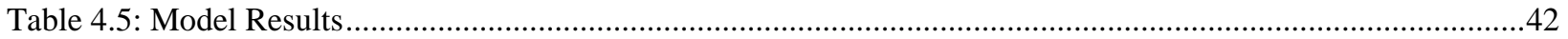

Table 4.6: Scenario Analysis Using the Regression Models .....................................................................52

\section{LIST OF FIGURES}

Figure 2.1 Cumulative Walking Distances to Bus and Light Rail Transit .....................................................21

Figure 3.1: Comparing Network and Circular Buffers ..........................................................................27

Figure 4.1: Average number of riders per stop in a typical weekday for the three regions.....................................33

Figure 4.2 Distribution of ridership and log-transformed ridership, TriMet ......................................................34

Figure 4.3 Distribution of ridership and log-transformed ridership, Lane Transit ...............................................34

Figure 4.4 Distribution of ridership and log-transformed ridership, Rogue Valley ............................................34

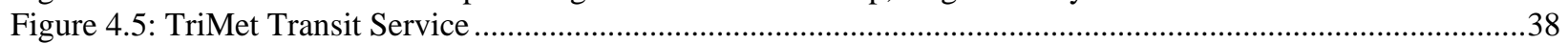

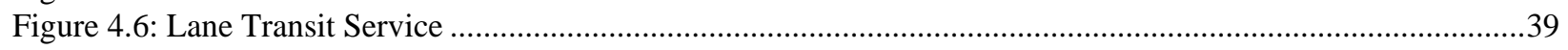

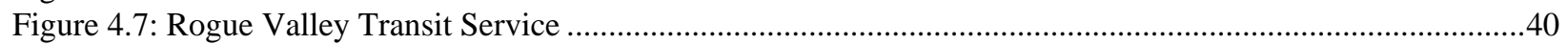

Figure 4.8: Distribution of Stops and \% of Population that is White ..................................................................44

Figure 4.9: Distribution of Stops and \% of Population that has a College Degree ................................................44

Figure 4.10: Distribution of Stops and \% of Population that is 65 or older ......................................................46

Figure 4.11: Effect of Pedestrian Destinations on Ridership, Controlling for Service Frequency ...........................49

Figure 4.12: Effect of Street Connectivity on Ridership, Controlling for Service Frequency ...............................49

Figure 4.13: Effect of Population Density on Ridership, Controlling for Service Frequency...................................50

Figure 4.14: Effect of Employment Density on Ridership, Controlling for Service Frequency ..............................50

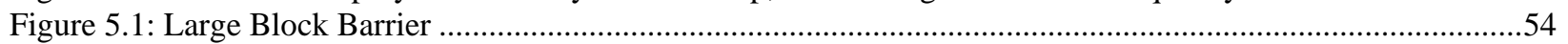

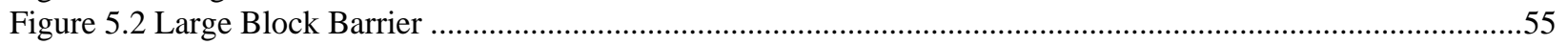




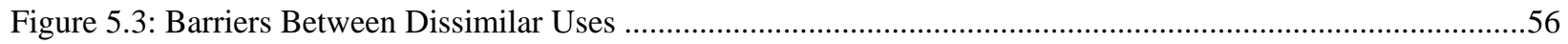

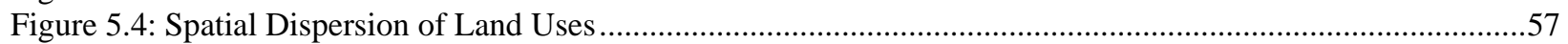

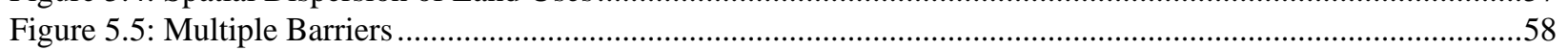

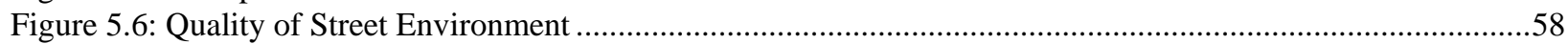





\section{EXECUTIVE SUMMARY}

This project sought to understand the relationship between urban form, transit service characteristics, and ridership measured at the stop level. Most previous work in this area has looked at these issues separately, by either linking system performance (e.g. on-time performance, cost, etc.) to ridership or exploring the connection between urban form (e.g. density) and transit use. This project seeks to synthesize these disparate approaches. While transit service characteristics (e.g. frequency, travel time, etc.) are important to help individuals reach their desired destinations, most transit users are pedestrians at the beginning and end of any transit trip. Therefore, focusing on the walkable zone around each transit stop is also important.

There are three methodological approaches to this project: (1) the development spatial indicators using geographic information systems (GIS); (2) regression analysis linking those indicators to ridership at the stop level; and (3) evaluation of micro-scale urban design factors. Three metropolitan regions in Oregon were included, representing a range of sizes and characteristics: TriMet (Portland), Lane Transit District (LTD) and the Rogue Valley Transit Authority (RVTD).

The regression analysis found that transit service variables explain about $41 \%$ of the variance in the TriMet model, 46\% in the LTD model, and 27\% in the RVTD model. Each extra minute of headway is associated with a four to five percent drop in ridership for RVTD and TriMet, compared to a two percent drop for LTD. In the Portland and Lane areas, transfer stops and coverage time were also associated with higher ridership. Light rail and bus rapid transit stops also had higher ridership than regular bus stops.

The land use variables explain about 4-5\% of the variance in the TriMet and LTD models and $17 \%$ in the RVTD model. The portion of land used for multi-family residential (MFR) is significantly and positively associated with higher ridership in all three locations. Commercial land use is also positively associated with ridership in all three areas, but only significant in Portland and Rogue Valley. The effect of MFR is somewhat higher in Lane County, while the effect of commercial land uses is larger in Portland and Rogue Valley. The proximity to possible pedestrian-oriented destinations is consistently significant in all three models; for each additional destination within a quarter-mile buffer of the transit stop, ridership goes up by 1-2\%. Street connectivity is positively associated with ridership inboth the TriMet and LTD models (insignificant in RVTD), indicating that the shorter walking distances afforded by increased connectivity likely improve accessibility. However, the connectivity variable accounts for less than $1 \%$ of the variation in each model. 


\subsection{INTRODUCTION}

This project seeks to understand the relationship between urban form, transit service characteristics, and ridership measured at the stop level. Most previous work in this area has looked at these issues separately. On the one hand, there has been work on the system performance of transit (e.g. on-time performance, cost, etc.) and on the other hand there has been a recent flurry of research exploring the connection between urban form and transit or pedestrian travel. This project seeks to synthesize these disparate approaches, recognizing that most transit riders are pedestrians on either end of their trip and thus the urban form surrounding each transit stop may be important to overall ridership. While transit service characteristics (e.g. frequency, travel time, etc.) are important to help individuals reach their desired destinations, most transit users are pedestrians at the beginning and end of any transit trip, thus focusing on the walkable zone around each transit stop is critically important. Thus, there are three potentially important contributions of this work when thinking about livability indicators for transit:

- Utilizing indicators found in the urban form literature on walking;

- Integrating urban design-scale analysis into transit stop accessibility; and

- Connecting actual ridership data at the stop level to the quantitative measures of the urban form around that stop.

There are three basic methodological approaches to this project: (1) the development of GISbased spatial indicators; (2) regression analysis linking those indicators with ridership data; and (3) evaluation of micro-scale urban design features. Three metropolitan regions in Oregon were included in the analysis. The service areas of TriMet, Lane Transit District (LTD) and the Rogue Valley Transit Authority (RVTD) represent different types of communities. TriMet serves the largest (approximately 1.8 million population) metropolitan area in the state, Portland. LTD serves the medium-sized Eugene-Springfield area, with a population of about 250,000. RVTD is in the smaller urbanized area of Medford and Ashland, with a population about 150,000. In addition, there are very different built environment conditions within each metropolitan area. By focusing on stop-level ridership and their local built environment, this project aims to find performance metrics that cuts across these differences.

The report first includes a review of the relevant literature. This literature was used to guide our analysis and model development. The next section explains the methodology. There are two findings sections, one focusing on the quantitative regression analysis followed by the urban design evaluation. The final section includes a discussion and recommendations relevant to planning and decision-making. 


\subsection{LITERATURE REVIEW}

This literature review covers two broad areas of research in two main sections. First is research on transit performance measures. These measures tend to focus on methods of assessing the level or quality of the transit service. The second section covers research that links urban form with transit use. This review focuses on the measures of urban form used by those studies, as well as the methods.

\subsection{TRANSIT PERFORMANCE MEASURES}

Transit agencies and local governments use performance measures to evaluate various aspects of a transit system's performance towards stated goals. Performance measures rely upon indicators in order to measure progress, so the types of performance measures used by an agency depends upon agency goals and the types of data routinely collected. Because performance measures determine the actions that must be taken to accomplish a goal, the measures should be carefully selected (Seggerman 2008).

Performance measures are primarily used for regulatory, internal agency, and functional uses. Regulatory uses consist of required reporting for the National Transit Database (NTD), compliance with the American Disability Act (ADA), grant applications, external reporting, municipal budgeting and reporting, and insurance purposes. Internal agency use of measures are to monitor performance of individuals and departments within the agency, to identify agency needs, to predict future performance, to compare performance with similar systems, and to identify passenger and community benefits. Functional uses consist of communicating agency goal achievement and community benefits, designing and monitoring service standards, monitoring economic performance, and management (Kittelson 2003).

A uniform standard of transit data collection does not exist outside of the reporting requirements of the NTD. Because of the types of data collected for the NTD, many of the transit performance measures currently in use are focused on ridership and financial performance, leaving measurement of the other aspects of transit such as quality of service and accessibility underrepresented (Kittelson 2003; Levinson 2004). In addition, the data routinely collected outside of the NTD requirements varies between agencies. As a result, the creation and application of performance measures may be agency specific.

Because of the diverse nature of performance goals and usage, the universe of transit performance measures is very broad. To better understand their application, performance measures can be classified into different categories of measurement outcomes. The key categories used are productivity, quality, and impact (Eboli 2011). 


\subsubsection{Productivity Measures}

Due to the federal reporting requirements for transit agencies, the majority of transit performance measures are intended to link financial assistance to improved performance (Hartman 1994). The overwhelming majority of measurements found in the literature reviewed consist of measures of productivity (Hartman 1994; Benn 1995; Furth 2000; FHWA 2008; Gleason 1982; Nakanishi 1997). Productivity measures are traditionally captured by the federal reporting requirements for the NTD and in the Federal Highway Administration's operational performance reports (FHWA 2008).

In a survey of 111 transit agencies, Benn (1995) found that transit agencies used the following five key variables in constructing productivity performance measures: vehicle hours, vehicle miles, ridership, revenue, and operating costs. These variables are then analyzed by distance, trip, passenger, time, and cost, creating, for example, composite and comparable measures such as passengers per mile.

Productivity can further be differentiated as measures of effectiveness and efficiency. The difference between effectiveness and efficiency is best summarized by Gleason and Barnum: “... effectiveness is 'doing the right thing' and efficiency is 'doing things right'” (Gleason 1982).

\subsubsection{Effectiveness}

Effectiveness measures reveal the progress towards a goal, determining the level of progress in absolute terms. Effectiveness measures focus on the relationship of inputs to consumed service (Eboli 2011). Common examples of effectiveness measures are cost per passenger trip, revenue per passenger trip, and ridership per expense (Furth 2000; Kittelson 2003).

\subsubsection{Efficiency}

Efficiency measures track services provided in comparison to the resources required to provide the service. Measures are expressed as a ratio between inputs and outputs (Gleason 1982). Common efficiency measures include cost to fare box revenue, cost per mile, subsidy per mile or passenger, and passengers per vehicle hour (Benn 1995; Gleason,1982; FHWA 2008).

\subsubsection{Quality Measures}

Quality measures attempt to assess the riders' perspective on service through either customer satisfaction surveys or quantitative measures performed by a transit agency. Measures are designed based upon their qualitative and quantitative nature, but linking the perceived quality of service with objective measures is important for an agency to properly evaluate service (Eboli 2011).

There is an increasing trend to move from tracking the performance of vehicles found in traditional productivity measures discussed above, to reflecting the conditions experienced by the passengers in the vehicles (Kittelson 2003; Benn 1995). Measures of quality indicate the 
level of passenger satisfaction of services provided, and as such represent performance from the rider's perspective. Measures of quality from the riders' perspective are often most meaningful at the route level, given the large variation between routes (Benn 1995).

Quality measures include average vehicle speed, safety, reliability, comfort, vehicle condition, on-time performance, service regularity and frequency, vehicle miles between road calls and accidents (Sheth 2007; FHWA 2008; Benn 1995; Nakanishi 1997; Barnum 2008). Quality measures may also include the availability of transit service, such as found in the Transit Capacity of Quality of Service Manual, although availability is more often categorized as community impact or accessibility.

\subsubsection{Impact/Availability Measures}

Impact measures are defined as how transit service affects, and is effected by the community in which it operates. Partly because of the nature of data required, impact measures are found to a lesser extent in the literature. Categories of impacts measures found consist of design standards, Transit Oriented Development (TOD), and accessibility measures. Whereas productivity measures reflect an agency's performance perspective and quality measures reflect a rider's perspective, impact measures determine the effects of transit service from a community's perspective. Impact measures may be viewed from either the impact of transit upon the community, or the impact of the community upon the transit system.

Measures found in the literature that rely upon land-use and community variables are categorized under accessibility (Kittelson 2003). Measuring accessibility may not be a natural fit for most transit agencies, which are accustomed to collecting data related ridership and revenue. Collecting this data may be outside of their experience in day-to-day operations, and is more likely to be done by local, regional, and metropolitan planning organizations (Benn 1995). Measures found include percent of people or jobs served by transit, percent of population and major activity centers (jobs, shopping, etc.) within transit service area, number of transportation options available vs. auto accessibility, percent of special-needs populations within transit service area (Kittelson 2003).

To plan for new service, transit agencies often set guidelines based upon expected performance or ridership or other performance objectives. In a survey of 111 transit agencies, Benn (1995) found that 86 percent of agencies use route design standards. The following were among the most common variables used in such standards:

- population and employment density

- spacing between routes and corridors

- equal geographic coverage throughout the local tax base

- network connectivity

- service equity

- proximity to residences 
- proximity to non-residential generators

- bus stop siting and spacing requirements.

Some of these measures imply a relationship between service coverage and ridership (e.g. proximity and density), while others are related to the politics of service provision (e.g. equal geographic coverage).

Transit and land use planning agencies are increasingly involved in the planning and implementation of transit-oriented development (TOD). From a transit agency perspective, the objective of TODs is to increase ridership. Therefore, a logical extension from measuring transit performance is measuring the performance of TODs. TOD-based performance measures include a more comprehensive set of variables than traditional transit or transportation measures (Fabish 2010). In measuring the transportation performance of TODs, Fabish and Hass use the variables of proximity to alternative transportation, mix and balance of uses, connectivity, and density. These measures developed for TODs might be applied to any transit stop, regardless of neighborhood design. Other urban form measures measuring TOD performance include improved street crossings, the number of connections available, and streetscape design (Pratt 2001).

Availability of transit may be measured in both the proximity to service and the service frequency. Temporal indicators of service availability are well defined in the literature, however measures of spatial accessibility are only beginning to be defined.

Availability of transit is primarily measured in frequency of service and is widely found in the literature (Benn 1995; Ryus 2000; FHWA 2008; Sheth 2007; Hartman 1994). Other measures of availability include route connectivity and times between transfers. Although the Transit Capacity and Quality of Service Manual categorizes availability under quality, they find that availability of transit is the most important factor because it determines whether or not transit is even a potential choice, regardless of quality of service (Levinson 2004). Here the terms of accessibility and availability are used as a single variable of availability, containing both the spatial and temporal measures.

Accessibility to transit is measured by a person's ability to access a transit stop within walking or biking distance, as most transit trips begin or end as pedestrian trips (Ryan 2009). Pedestrian accessibility measures are built upon the idea that the quality of the pedestrian environment around transit stops effects transit ridership.

An increasing trend in measuring access is replacing geodetic distance (as the crow flies) with street network distances. The use of the street network reveals a much clearer picture of the actual accessibility to transit stops, and allows for measurements of walkability (Ryus 2000; Foda 2010; Schlossberg, 2006; Schlossberg 2004).

\subsubsection{Composite Measures}

Combining transportation and land-use performance measurements to evaluate transit agencies, the Florida Transit Level of Service Indicator (TLOS) uses service coverage and frequency, 
pedestrian routes near transit stops, and population and job density to measure transit service (Ryus 2000). This measure is based upon both the accessibility of the built environment and the availability (frequency) of service to determine an overall transit level of service at each transit stop. In designing the TLOS, the authors found that access to transit is one of the most important measures of transit quality. If access to transit is difficult, then the other aspects of transit quality will not matter to a rider (Ryus 2000).

TriMet in Portland Oregon is using accessibility based performance measures to develop its "Pedestrian Network Analysis" tool. The tool is designed to assign a weighted rank to each stop in the agency's system to identify the areas in need of future investment. Accessibility measures are based upon the pedestrian and bicycle network, traffic volume and speed, and population and job densities surrounding each stop (TriMet 2010).

\subsubsection{Summary}

Table 2.1 summarizes the measures discussed above, while Table 2.2 presents some of the specific findings from key sources. These measures will factor into our analysis in two ways. We intend to develop models that link transit performance (the "dependent variable") to a set of factors ("independent variables"). The transit performance measures listed in Table 2.1 are likely dependent and independent variables. The primary dependent variable of interest is ridership, a key measure of transit productivity. Ridership is directly affected by the quality and availability of the service - key independent variables. Some of these variables, e.g. frequency of service, are not directly linked to urban form. Many impact/availability measures, on the other hand, are related to urban form. 
Table 2.1: Summary of Transit Performance Measures

\begin{tabular}{|c|c|}
\hline Category & Examples \\
\hline Productivity & $\begin{array}{l}\text { vehicle hours } \\
\text { vehicle miles } \\
\text { ridership } \\
\text { revenue } \\
\text { operating costs }\end{array}$ \\
\hline Effectiveness & $\begin{array}{l}\text { cost per passenger trip } \\
\text { revenue per passenger trip } \\
\text { ridership per expense }\end{array}$ \\
\hline Efficiency & $\begin{array}{l}\text { cost to fare box revenue } \\
\text { cost per mile } \\
\text { subsidy per mile or passenger } \\
\text { passengers per vehicle hour }\end{array}$ \\
\hline Quality & $\begin{array}{l}\text { the level of passenger satisfaction } \\
\text { average vehicle speed } \\
\text { safety } \\
\text { reliability } \\
\text { comfort } \\
\text { vehicle condition } \\
\text { on-time performance } \\
\text { service regularity and frequency } \\
\text { vehicle miles between road calls and accidents }\end{array}$ \\
\hline Impact/Availability & $\begin{array}{l}\text { percent of people or jobs served by transit } \\
\text { percent of population and major activity centers (jobs, shopping, etc.) within transit } \\
\text { service area } \\
\text { number of transportation options available vs. auto accessibility } \\
\text { percent of special-needs populations within transit service area } \\
\text { proximity (e.g. route distance to stop) } \\
\text { route connectivity and times between transfers }\end{array}$ \\
\hline
\end{tabular}


Table 2.2: Findings from Key Sources on Transit Performance

\begin{tabular}{|c|c|c|}
\hline Title & Categories Used & Performance Measures \\
\hline $\begin{array}{l}\text { Bus Route Evaluation } \\
\text { Standards (Benn 1995) }\end{array}$ & $\begin{array}{l}\text { Impact, Availability, } \\
\text { Productivity, Quality }\end{array}$ & $\begin{array}{l}\text { Impact: Population \& employment density, spacing, } \\
\text { connectivity; Availability: Level of service frequency; } \\
\text { Productivity: Pass./cost/revenue/subsidy per hour/mile; } \\
\text { Quality: Complaints, missed trips, accidents, vehicle } \\
\text { condition }\end{array}$ \\
\hline $\begin{array}{l}\text { TOD: Traveler Response to } \\
\text { Transportation System } \\
\text { Changes (Pratt 2001) }\end{array}$ & Impact & $\begin{array}{l}\text { Ridership, density, streetscape, mixed-use, pedestrian counts, } \\
\text { improved street crossings, increase in property value, public } \\
\text { perception, number of connections, parking, private } \\
\text { investment, number of stores }\end{array}$ \\
\hline $\begin{array}{l}\text { Data Analysis for Bus } \\
\text { Planning and Monitoring } \\
\text { (Furth 2000) }\end{array}$ & Productivity & Ridership, revenue per passenger, schedule adherence \\
\hline $\begin{array}{l}2008 \text { Conditions and } \\
\text { Performance: Ch } 4 \\
\text { Operational Performance } \\
\text { (FHWA 2008) }\end{array}$ & Productivity, Quality & $\begin{array}{l}\text { Productivity: Average operating speeds, vehicle occupancy, } \\
\text { vehicle utilization (Passenger miles/Capacity), revenue } \\
\text { miles; Quality: Frequency \& reliability, seating conditions }\end{array}$ \\
\hline $\begin{array}{l}\text { Toward Valid Measures of } \\
\text { Public Sector Productivity: } \\
\text { Performance Measures in } \\
\text { Urban Transit (Gleason \& } \\
\text { Barnum 1982) }\end{array}$ & Productivity & $\begin{array}{l}\text { Cost per passenger, passengers per vehicle hour, vehicle } \\
\text { miles per operator, cost per vehicle mile, cost per vehicle } \\
\text { hour, and the ratio of cost to farebox revenue }\end{array}$ \\
\hline $\begin{array}{l}\text { Bus Performance Indicators } \\
\text { On-Time Performance and } \\
\text { Service Regularity } \\
\text { (Nakanishi 1997) }\end{array}$ & Quality & $\begin{array}{l}\text { On-time performance, service regularity, headway } \\
\text { distributions, origin-destination travel time (wait, dwell, \& } \\
\text { travel times) }\end{array}$ \\
\hline $\begin{array}{l}\text { Performance evaluation of } \\
\text { bus routes: A provider and } \\
\text { passenger perspective (Sheth, } \\
\text { et al 2007) }\end{array}$ & Quality, Impact & $\begin{array}{l}\text { Quality: Reliability, \& trip time; Impact; Frequency, } \\
\text { accessibility of stops within } 400 \text { meters of homes, parking, } \\
\text { population density, route connectedness }\end{array}$ \\
\hline $\begin{array}{l}\text { A Guidebook for Developing } \\
\text { a Transit Performance- } \\
\text { Measurement System } \\
\text { (Kittelson Associates 2003) }\end{array}$ & $\begin{array}{l}\text { Accessibility, Quality, } \\
\text { Productivity, Community } \\
\text { Impact }\end{array}$ & $\begin{array}{l}\text { Accessibility: Number of people served by transit, percent of } \\
\text { population living within defined distance of transfer } \\
\text { opportunities, number of transportation options available, } \\
\text { transit vs. auto accessibility }\end{array}$ \\
\hline $\begin{array}{l}\text { The Role of Performance- } \\
\text { Based Measures in } \\
\text { Allocating Funding for } \\
\text { Transit Operations (Hartman } \\
\text { et al 1994) }\end{array}$ & Productivity, Quality & $\begin{array}{l}\text { Cost Efficiency: (Cost per mile, per hour, per vehicle, } \\
\text { Ridership per expense), Cost Effectiveness: (Cost per } \\
\text { passenger trip, revenue per passenger trip, ridership per } \\
\text { expense), Service Utilization: (Passenger trips per mile, per } \\
\text { hour, per capita), Vehicle utilization: (Miles per vehicle), } \\
\text { Quality of service: (Average speed, vehicle miles between } \\
\text { road calls, between accidents), Labor productivity: } \\
\text { (Passenger trips per employee, vehicle miles per employee), } \\
\text { Coverage: (Vehicle miles per capita, per service) }\end{array}$ \\
\hline $\begin{array}{l}\text { Transit Capacity and Quality } \\
\text { of Service Manual (Kittelson } \\
\text { Associates 2003) }\end{array}$ & Availability, Quality & $\begin{array}{l}\text { Availability: Access to transit service, trip time; Quality: } \\
\text { Real and perceived chances of being involved in an accident } \\
\text { (safety) or being the victim of a crime (security) while using } \\
\text { transit, passengers' experiences using transit }\end{array}$ \\
\hline $\begin{array}{l}\text { Florida Transit Level of } \\
\text { Service Indicator (Ryus et al } \\
\text { 2000) }\end{array}$ & $\begin{array}{l}\text { Availability, } \\
\text { Accessibility, Impact }\end{array}$ & $\begin{array}{l}\text { Availability: Service coverage, service frequency, hours of } \\
\text { service; Accessibility: Pedestrian routes to and from transit } \\
\text { stops; Impacts: Population, job density }\end{array}$ \\
\hline
\end{tabular}




\subsubsection{Differing Perspectives}

Many of the measures found in the literature differ between the perspective of the agency or the passenger. Productivity may mean different things to a provider compared to a consumer. Productivity measured from the transit agency's perspective measures service against the funding required for service provided. From the rider's perspective, productivity determines the levels of overall access to and quality of service provided. "According to the provider's viewpoint, efficient service along a route is where the transit agency will provide adequate service at the least cost whereas for the customer, efficient service along a route is where one that has the most quality attributes such as the shortest travel time or the highest level of seating comfort” (Sheth 2007).

An increasing trend is to measure transit performance from the passenger's point of view, moving measures from a vehicle orientation to a people orientation (Levinson 2004; Benn 1995). Measuring performance from the passenger's perspective means evaluating performance as outcomes based, rather than just focusing on the inputs required to operate the service.

\subsection{RESEARCH LINKING URBAN FORM AND TRANSIT RIDERSHIP}

Land use and design around transit stops or stations are very important factors in influencing transit demand, however, few studies exist on this topic. Most previous empirical studies focus on transit ridership at the route-level and largely assume homogeneous service levels and land use along each route (Chu 2004). However, these assumptions are not valid, especially for routes that cross areas with dramatic changes in land use as well as social-demographic characteristics, for example, from central business districts (CBD) to suburban areas. Therefore, stop-level transit demand models are needed to take into account stop-level land use characteristics, such as the surrounding pedestrian environment. Stop-level models are particularly useful to connect transit demand with demographic and land use characteristics (Peng 1997). Table 2.3 lists the stop-level studies we identified. The following sections will delineate some specific measures from these studies that can serve as potential indicators connecting issues of livability to transit use. 
Table 2.3: Studies on Stop-Level Transit Ridership Model

\begin{tabular}{|c|c|c|c|}
\hline Sources & Title & Transit Type & $\begin{array}{l}\text { Location of } \\
\text { Study }\end{array}$ \\
\hline Banerjee et al. 2005 & $\begin{array}{l}\text { Increasing Bus Transit Ridership: Dynamics of } \\
\text { Density, Land Use, and Population Growth }\end{array}$ & Rapid Bus & $\begin{array}{l}\text { Los Angeles, } \\
\text { California }\end{array}$ \\
\hline Cervero 2006 & $\begin{array}{l}\text { Alternative Approaches to Modeling the Travel- } \\
\text { Demand Impacts of Smart Growth }\end{array}$ & $\begin{array}{l}\text { Heavy Rail; } \\
\text { Light Rail }\end{array}$ & $\begin{array}{l}\text { San Francisco } \\
\text { Bay Area; St. } \\
\text { Louis }\end{array}$ \\
\hline Chu 2004 & Ridership Models at the Stop Level & Bus & $\begin{array}{l}\text { Jacksonville, } \\
\text { Florida }\end{array}$ \\
\hline $\begin{array}{l}\text { Estupinan and } \\
\text { Rodriguez } 2008\end{array}$ & $\begin{array}{l}\text { The Relationship Between Urban Form and } \\
\text { Station Boardings for Bogota's BRT }\end{array}$ & $\begin{array}{c}\text { Bus Rapid } \\
\text { Transit (BRT) }\end{array}$ & $\begin{array}{c}\text { Curitiba, } \\
\text { Bogota }\end{array}$ \\
\hline Lin and Shin 2008 & $\begin{array}{l}\text { Does Transit-Oriented Development Affect } \\
\text { Metro Ridership? Evidence from Taipei, Taiwan }\end{array}$ & Metro & Taipei, Taiwan \\
\hline Mishra et al. 2012 & $\begin{array}{l}\text { Performance indicators for public transit } \\
\text { connectivity in multi-modal transportation } \\
\text { networks }\end{array}$ & Rail and Bus & $\begin{array}{l}\text { Washington } \\
\text { Metro; } \\
\text { Maryland } \\
\text { Transit } \\
\end{array}$ \\
\hline $\begin{array}{l}\text { Pulugurtha and Agurla } \\
2012\end{array}$ & $\begin{array}{l}\text { Assessment of Models to Estimate Bus-Stop } \\
\text { Level Transit Ridership using Spatial Modeling } \\
\text { Methods }\end{array}$ & Bus & Charlotte, NC \\
\hline Ryan and Frank 2009 & Pedestrian Environments and Transit Ridership & Bus & $\begin{array}{l}\text { San Diego, } \\
\text { California }\end{array}$ \\
\hline
\end{tabular}

\subsubsection{Variables Included and their Effect on Ridership}

\subsubsection{Built Environment Variables}

Researchers have often used the 3Ds to describe the built environment: density, diversity and design.

For the evaluation of density around the transit stop/station, population density, employment density, housing density, and building density are the commonly used variables. Density around transit stop/station is assumed to have positive correlation with transit ridership, and several empirical studies did find this relationship was significant (Chu 2004; Banerjee et al. 2005; Cervero 2006; Lin and Shin 2008; Mishra et al 2012). However, density itself may be too broad to capture the micro built environment which may be more essential to the transit ridership. The findings from the studies examined are shown in Table 2.4 . 
Table 2.4: Density Variables

\begin{tabular}{|c|c|c|c|}
\hline Sources & $\begin{array}{l}\text { Built Environment } \\
\text { Variables: Density }\end{array}$ & Method to Create the Variable & $\begin{array}{l}\text { Relationship } \\
\text { with Transit } \\
\text { Ridership } \\
\end{array}$ \\
\hline \multirow[t]{2}{*}{ Banerjee et al. 2005} & Housing Density & & + \\
\hline & Employment Density & & + \\
\hline \multirow[t]{3}{*}{ Cervero 2006} & $\begin{array}{l}\text { Population and } \\
\text { Employment Density }\end{array}$ & $\begin{array}{l}\text { Station-area density: Natural log of } \\
\text { sum of population and employment } \\
\text { within } 1 / 2 \text { mile }\end{array}$ & + \\
\hline & Catchment Populations & $\begin{array}{l}\text { Natural log of population of defined } \\
\text { station catchment area }\end{array}$ & ns \\
\hline & Housing densities & $\begin{array}{l}\text { Number of dwelling units per gross } \\
\text { acre within } 1 / 2 \text {-mile radius of station }\end{array}$ & ns \\
\hline \multirow[t]{3}{*}{ Chu 2004} & $\begin{array}{l}\text { Jobs in Catchment Area by } \\
\text { Road }\end{array}$ & $\begin{array}{l}\text { Jobs located within buffers served by a } \\
\text { stop }\end{array}$ & + \\
\hline & $\begin{array}{l}\text { Persons Up and } \\
\text { Downstream without } \\
\text { Transfer in } 1 \mathrm{hr} \\
\end{array}$ & & + \\
\hline & $\begin{array}{l}\text { Jobs Up and Downstream } \\
\text { without Transfer in } 1 \mathrm{hr}\end{array}$ & & + \\
\hline $\begin{array}{l}\text { Estupian and } \\
\text { Rodriguez } 2008\end{array}$ & Neighborhood Density & Persons per hectare & \\
\hline \multirow[t]{3}{*}{ Lin and Shin 2008} & Residential Density & $\begin{array}{l}\text { Number of residents/area of residential } \\
\text { floor space }\end{array}$ & ns \\
\hline & Employment Density & $\begin{array}{l}\text { Number of employees/area of working } \\
\text { floor space }\end{array}$ & ns \\
\hline & Building Density & Area of floor space & + \\
\hline Mishra et al. 2012 & $\begin{array}{l}\text { Residential/Employment } \\
\text { density }\end{array}$ & $\begin{array}{l}\text { Ratio of households and employment in } \\
\text { a zone to the unit area }\end{array}$ & + \\
\hline Ryan and Frank 2009 & Residential Density & $\begin{array}{l}\text { \# of housing units per net residential } \\
\text { acre }\end{array}$ & \\
\hline \multirow[t]{4}{*}{ Zhao et al. 2005b } & HH Density & Household density & - \\
\hline & Pop Density & Population density & + \\
\hline & Emp Density & Employment density & + \\
\hline & Total Density & $\begin{array}{l}\text { Total employment plus population } \\
\text { density }\end{array}$ & + \\
\hline \multicolumn{4}{|c|}{$\begin{array}{l}\text { Notes: } \\
\text { +: significantly positive relationship } \\
\text {-: significantly negative relationship }\end{array}$} \\
\hline
\end{tabular}

Land use mix refers how the diversity of land uses in a given area. The relationship between the land use mix around the transit station/stop and transit ridership is not clear. Even though many studies have shown that residents living in a mixed land use environment would be more likely to use transit than residents in a primarily residential neighborhood (e.g. Cervero 1996), few examined the relationship between the land use mix around transit stop/station and transit ridership.

Jobs-housing balance, entropy, and the proportion of each type of land use are the common ways to create land use diversity variables (Table 2.5). Among the studies reviewed, Lin and Shin 
(2008) and Cervero (2006) did not find a significant relationship between land use mix and transit ridership, and they argued that this might result from cultural differences: mixed land use was popular in Chinese societies, whereas separate land use was popular in Northern America. UNC (2006) employed the entropy, proportion of residential land use and number of nonresidential places as indicators of land use diversity, and concluded that there was no significant relationship between land use mix variable created by entropy and ridership, but they did find that lower proportion of residential land use, having a lot of places that people can visit for a long time, and having high employment were positively associated with ridership. Similarly, Banerjee et al. (2005) found significant and positive relationship between percentage of nonresidential land use and rapid bus ridership. They also found that land use diversity was significant, indicating a positive relationship with rapid transit ridership when tested alone. In model testing, however, findings of the combined effects of population density and land use mix, showed that land-use mix or diversity had no effect. One of the reasons for the insignificant relationship between land use mix and transit ridership may be the methods these studies used to create the land use mix variables. Variables that use entropy as a measure, which is common, may not capture the real and micro land use diversity, since most of land use information used for calculating entropy is only available at aggregate level.

The impact of land use mix on transit use was found to be greater at employment destinations than at residential origins (Cervero 2002). Having a mix of uses in close proximity to an employment destination facilitates people who use transit to commute to be able to walk to lunch or to run errands.

Table 2.5: Diversity Variables

\begin{tabular}{|c|c|c|c|}
\hline Sources & $\begin{array}{l}\text { Built Environment } \\
\text { Variables: Diversity }\end{array}$ & Method to Create the Variable & $\begin{array}{l}\text { Relationship } \\
\text { with Transit }^{\text {Ridership }}\end{array}$ \\
\hline \multirow[t]{2}{*}{ Banerjee et al. 2005} & $\begin{array}{l}\text { Non-Residential Land } \\
\text { Use }\end{array}$ & Percentage of non-residential land use & + \\
\hline & Land Use Diversity Index & $\begin{array}{l}\text { Land Use Diversity =LD }=1-[\text { Sum } \\
\text { (Ia1 }, \text { Ia2 }, \text { Ia3 }, \ldots . . . \text { Ian )] } \\
I a_{\mathbf{1}}=\frac{a_{i}^{2}}{A^{2}} \cdot a_{i} \text { :area of each type of } \\
\text { land use, A: total land area }\end{array}$ & + \\
\hline Cervero 2006 & Land Use Mix & $\begin{array}{l}\text { Mixed-use entropy index within } 1 / 2- \\
\text { mile radius of station }\end{array}$ & ns \\
\hline Chu 2004 & See Density Measures & & \\
\hline \multirow{2}{*}{$\begin{array}{l}\text { Estupinan and } \\
\text { Rodriguez } 2008 \\
\end{array}$} & Land Use Mix & Land use index (0-100) Audit & \\
\hline & Amenities & Index of amenities (0-100) Audit & \\
\hline \multirow[t]{3}{*}{ Lin and Shin 2008} & Job-Housing Balance & $\begin{array}{l}\text { Job-Housing balance }=1 \text {-[absolute } \\
\text { value (Total employment- } 1.5 \times \text { Total } \\
\text { housing units)/(Total employment }+1.5 \\
\text { x Total housing units) } \\
\text { (from Ewing et al., 1996) }\end{array}$ & ns \\
\hline & $\begin{array}{l}\text { Percentage of Retail and } \\
\text { Service Floor Space }\end{array}$ & $\begin{array}{l}\text { Area of retail and service floor } \\
\text { space/area of total floor space }\end{array}$ & ns \\
\hline & Land Use Variety & Entropy & ns \\
\hline
\end{tabular}




\begin{tabular}{|c|c|c|c|}
\hline \multirow[t]{4}{*}{$\begin{array}{l}\text { Pulugurtha and Agurla } \\
2012\end{array}$} & Residential Area & $\begin{array}{l}\text { Land use area within walkable distance } \\
\text { from a bus stop }\end{array}$ & - \\
\hline & Industrial Area & & - \\
\hline & Commercial Area & & + \\
\hline & Institutional Area & & + \\
\hline \multirow[t]{2}{*}{ Ryan and Frank 2009} & Retail Floor Area Ratio & $\begin{array}{l}\text { Square Footage of retail buildings } \\
\text { divided by SF of retail parcels }\end{array}$ & \\
\hline & Land Use Mix & $\begin{array}{l}\text { Proportion of seven land use types } \\
\text { within station area }\end{array}$ & \\
\hline \multirow[t]{2}{*}{ UNC 2006} & Land Use Mix & Entropy & $\mathrm{ns}$ \\
\hline & $\begin{array}{l}\text { Proportion of Residential } \\
\text { Land Area }\end{array}$ & & - \\
\hline \multirow[t]{2}{*}{ Zhao et al. $2005^{b}$} & Jobs-HH Balance & Jobs-housing balance & - \\
\hline & Avg. Entropy & Land use mix & - \\
\hline
\end{tabular}

Notes:

a + : significantly positive relationship

-: significantly negative relationship

ns: no significant relationship was found

blank cell means the variable was not included into the final model.

Design is perhaps the variable most affected by micro-level characteristics of built environment around a transit station/stop. Design can capture the walking and accessibility conditions of station/stop area, as well as the station/stop facilities (e.g. bus shelters and signage). A walkingand biking-friendly environment around transit station may attract more people to use transit. Also transit station/stop facilities, such as shelters, posted schedules and maps, lighting, paved landings, bike racks, seating, etc. may contribute to transit ridership.

The findings with respect to design variables from the studies examined appear in Table.2.6 Estupinan and Rodriguez (2008) found that street connectivity had significantly positive relationship with transit ridership, however, negative correlation with transit ridership was found by Lin and Shin (2008) and UNC (2006). For the UNC studies, however, the coefficient for percentage of four-way intersections was so small that the impact might be considered negligible. UNC (2006) evaluated the micro accessibility environment, road design, pedestrian/bicycle environment, and architecture design at the stop level though auditing. They concluded that: bus stop amenities, such as having signs, shelters, schedules, lighting, and paved landing areas were significantly and positively correlated with increased ridership; pedestrian/bicycle friendly design was positively associated with ridership; and buildings designed with interesting features are likely to encourage ridership. Estupinan and Rodriguez (2008) also employed an audit score to evaluate the micro design around BRT stations, and they also concluded that walk/bike friendly design around station contributed to BRT ridership.

Table 2.6: Design Variables

\begin{tabular}{l|l|l|l}
\hline \multirow{2}{*}{ Sources } & $\begin{array}{l}\text { Built Environment } \\
\text { Variables: Design }\end{array}$ & Method to Create the Variable & $\begin{array}{l}\text { Relationship } \\
\text { with Transit } \\
\text { Ridershipa }\end{array}$ \\
\hline Ryan and Frank 2009 & Walkability Index & $\begin{array}{l}\text { 2x[Z(Land use mix]+Z(Residential } \\
\text { Density)+Z(Retail } \\
\text { FAR)+Z(Intersection Density) }]\end{array}$ & + \\
& & \# of intersections per acre & \\
\cline { 2 - 4 } & Intersection Density & \\
\hline
\end{tabular}




\begin{tabular}{|c|c|c|c|}
\hline Sources & $\begin{array}{l}\text { Built Environment } \\
\text { Variables: Design }\end{array}$ & Method to Create the Variable & $\begin{array}{l}\text { Relationship } \\
\text { with Transit } \\
\text { Ridershipa }\end{array}$ \\
\hline \multirow{13}{*}{$\begin{array}{l}\text { Estupinan and } \\
\text { Rodriguez } 2008\end{array}$} & Bike Path & Presence of bike path (0-1) Audit & \\
\hline & Sidewalk & $\begin{array}{l}\text { Buffer width between sidewalk and } \\
\text { road }(0-3) \text { Audit }\end{array}$ & \\
\hline & Traffic Control & Traffic control index(0-100) Audit & \\
\hline & Sidewalk Continuity & Sidewalk Continuity(0-3) Audit & \\
\hline & Sidewalk Width & Sidewalk Width (0-3) Audit & \\
\hline & Sidewalk Quality & Sidewalk Quality (0-1) Audit & \\
\hline & Amenities & Index of amenities (0-100) Audit & \\
\hline & Street Connectivity & $\begin{array}{l}\text { Sum of three way and four way } \\
\text { intersections }\end{array}$ & \\
\hline & Road Density & Linear kilometers in buffer & \\
\hline & Walking Support & Factor analysis & + \\
\hline & Barriers to Car Use & Factor analysis & + \\
\hline & Safety and Security & Factor analysis & + \\
\hline & Connectivity & Factor analysis & + \\
\hline \multirow[t]{4}{*}{ Lin and Shin 2008} & $\begin{array}{l}\text { Percentage of Four-Way } \\
\text { Intersections }\end{array}$ & $\begin{array}{l}\text { Number of four way } \\
\text { intersections/number of intersections }\end{array}$ & - \\
\hline & Sidewalk Length & Length of sidewalk & ns \\
\hline & Number of Blocks & Number of blocks & ns \\
\hline & Parking Space & $\begin{array}{l}\text { Number of parking spaces/area of floor } \\
\text { space }\end{array}$ & ns \\
\hline \multirow[t]{2}{*}{ Chu 2004} & Pedestrian Factor & $\begin{array}{l}\text { Traffic signal in immediate vicinity; } \\
\text { Median type; Number of lanes on } \\
\text { street; Pedestrian street-crossing delay; } \\
\text { TLOS pedestrian adjustment factor; } \\
\text { P.M. peak hour traffic volume; } \\
\text { Presence of continuous sidewalk in } \\
\text { stop vicinity. }\end{array}$ & + \\
\hline & Including a Trolley Stop & & + \\
\hline \multirow[t]{8}{*}{ Zhao et al. 2005b } & Ave. Residents & $\begin{array}{l}\text { Average walking distance from } \\
\text { residence }\end{array}$ & - \\
\hline & Bus Distance & $\begin{array}{l}\text { Shortest walking distance from each } \\
\text { TAZ centroid to the nearest bus stop }\end{array}$ & - \\
\hline & Street Density & & + \\
\hline & Intersection Density & $\begin{array}{l}\text { \# internal streets intersecting with the } \\
\text { boundary }\end{array}$ & + \\
\hline & Highway Accessibility & & + \\
\hline & Transit Accessibility & & + \\
\hline & Sidewalk & $\begin{array}{l}\text { Percentage of street lengths with } \\
\text { sidewalk in the quarter mile buffer } \\
\text { around bus stop }\end{array}$ & + \\
\hline & Sidewalk A\&C & $\begin{array}{l}\text { Percentage of arterials and collectors } \\
\text { with sidewalk in quarter mile around } \\
\text { bus stops in a TAZ }\end{array}$ & + \\
\hline Banerjee et al. 2005 & None & & + \\
\hline
\end{tabular}




\begin{tabular}{l|l|l|l}
\hline \multirow{2}{*}{ Sources } & $\begin{array}{l}\text { Built Environment } \\
\text { Variables: Design }\end{array}$ & Method to Create the Variable & $\begin{array}{l}\text { Relationship } \\
\text { with Transit } \\
\text { Ridershipa }\end{array}$ \\
\hline UNC 2006 & Intersection Density & $\begin{array}{l}\text { Number of four way } \\
\text { intersections/number of intersections }\end{array}$ & - \\
\cline { 2 - 4 } & Ped/Bike Facilities & Audit score & + \\
\cline { 2 - 4 } & Stop Index & Audit score & + \\
\cline { 2 - 4 } & Road Index & Audit score & + \\
\cline { 2 - 4 } & Architecture Index & Audit score & + \\
\cline { 2 - 4 } & Neighborhood index & Audit score & - \\
\hline
\end{tabular}

Notes:

a + : significantly positive relationship

-: significantly negative relationship

ns: no significant relationship was found

blank cell means the variable was not included into the final model.

\subsubsection{Level of Service Variables}

In this research, the level of transit service can be considered a control variable, since the focus is on the relationship between urban form and transit use. In the studies examined, level of service of transit was primarily assessed by transit frequency, transit alternatives, and route density, which all proved to have significant and positive relationships with transit ridership. Mishra et al. (2012) estimated the connecting power of a transit line at a node by a function of the average vehicle capacity of the transit line, the frequency on the transit line, the daily hours of operation of the transit line, the speed of the transit line, and the distance of the node to the destination. Ryan and Frank (2009) developed a measure of level of service to capture the level of transit accessibility to multiple destinations as well as the amount of waiting time between buses, and found that places with more routes and shorter wait times had higher bus ridership. Estupinan and Rodriguez (2008) predicted BRT ridership using five variables: 1)number of bus transit alternatives to BRT; 2) presence of a feeder bus; 3) number of routes, 4) types of station defined by size; and 5) number of vehicles per day per station. The study found that BRT service was significantly and positively correlated with BRT ridership. Cervero (2006) estimated the peak-hour rail station boardings at San Francisco Bay Area, and found that train frequency and feeder bus service were positively and significantly associated with station boardings. Banerjee et al. (2005) used the number of transit linkages with the availability of metro rail at a bus stop as measures of level of service to predict rapid bus ridership. The study found that these two variables had significant, positive effects on bus ridership.

A summary of variables used for measuring the level of service in these studies and their relationship with ridership have been listed in Table 2.7. 
Table 2.7: Variables Measuring Transit Level of Service

\begin{tabular}{|c|c|c|}
\hline Sources & Level of Services Variables & $\begin{array}{l}\text { Relationship } \\
\text { with Transit } \\
\text { Ridership }\end{array}$ \\
\hline \multirow[t]{2}{*}{ Banerjee et al. 2005} & Number of transit linkages & + \\
\hline & Availability of metro rail & + \\
\hline \multirow[t]{2}{*}{ Cervero 2006} & Service Frequency: number of train cars in one direction & + \\
\hline & Feeder Bus Service: number of feeder buses arriving at station & + \\
\hline \multirow[t]{3}{*}{ Chu 2004} & LOS within one-minute walking & + \\
\hline & LOS within two-five minutes walking & + \\
\hline & Number of other TLOS stops in catchment area & - \\
\hline $\begin{array}{l}\text { Estupinan and } \\
\text { Rodriguez } 2008\end{array}$ & $\begin{array}{l}\text { Transit Supply-number of bus transit alternatives available } \\
\text { different from BRT; Presence of feeder bus; number of Routes; } \\
\text { Types of Station defined by size; Number of vehicles per day per } \\
\text { station }\end{array}$ & + \\
\hline \multirow[t]{4}{*}{ Mishra et al. 2012} & Average vehicle capacity & \\
\hline & Frequency & \\
\hline & Daily hours of operation & \\
\hline & Speed & \\
\hline $\begin{array}{l}\text { Ryan and Frank } \\
2009\end{array}$ & $\begin{array}{l}\text { Numbers of bus routes serving a bus stop divided by the mean wait } \\
\text { time of all route serving the bus stop }\end{array}$ & + \\
\hline \multirow[t]{5}{*}{ Zhao et al. 2005} & Composite average peak hour headway & - \\
\hline & Average number of bus runs per stop & + \\
\hline & $\begin{array}{l}\text { Percentage of TAZ area served by transit based on quarter mile } \\
\text { buffers around bus stops }\end{array}$ & + \\
\hline & Bus Route Density in feet per acre in a TAZ & + \\
\hline & Number of Bus Routes in a TAZ & + \\
\hline
\end{tabular}

Notes:

+: significantly positive relationship

-: significantly negative relationship

ns: no significant relationship was found

Blank cell means the variable was not included into the final model.

\subsubsection{Socio-Demographic Variables}

Socio-demographic variables serve as control variables in transit ridership models, and include income, education, age, race, gender, car ownership etc. In general, most studies have concluded that the following characteristics are associated with lower ridership: higher income, greater proportion of white people, male, persons younger than 18, and owning a car. A summary of variables used for measuring socio-demographic characteristics of transit users in these studies and their relationship with ridership have been listed in Table 2.8 . 
Table 2.8: Variables Measuring Socio-Demographic Characteristics of Transit Users

\begin{tabular}{|c|c|c|c|c|c|}
\hline Sources & Income & Race & Gender & Age & $\begin{array}{l}\text { Auto } \\
\text { Ownership }\end{array}$ \\
\hline Banerjee et al.2005 & Income & $\begin{array}{l}\text { Hispanic } \\
\text { Population }\end{array}$ & & & Car Ownership \\
\hline Chu 2004 & $\begin{array}{l}\text { Median HH } \\
\text { Income }\end{array}$ & $\begin{array}{l}\text { Share of } \\
\text { Persons } \\
\text { White }\end{array}$ & $\begin{array}{l}\text { Share of } \\
\text { Female }\end{array}$ & $\begin{array}{l}\text { Share of Persons } \\
\text { Under } 18 \text { in } \\
\text { Catchment Area }\end{array}$ & $\begin{array}{l}\text { No-Vehicle HH } \\
\text { in Catchment } \\
\text { Area }\end{array}$ \\
\hline Lin and Shin 2008 & $\begin{array}{l}\text { Household } \\
\text { Income }\end{array}$ & & & & $\begin{array}{l}\text { Passenger Car } \\
\text { Ownership; } \\
\text { Motorcycle } \\
\text { Ownership }\end{array}$ \\
\hline $\begin{array}{l}\text { Pulugurtha and } \\
\text { Agurla } 2012\end{array}$ & $\begin{array}{l}\text { Mean } \\
\text { household } \\
\text { income }\end{array}$ & $\begin{array}{l}\text { Asian } \\
\text { Population }\end{array}$ & & & $\begin{array}{l}\text { Households } \\
\text { with no vehicles }\end{array}$ \\
\hline Ryan and Frank 2009 & Income & $\begin{array}{l}\text { Percent } \\
\text { White }\end{array}$ & $\begin{array}{l}\text { Percent } \\
\text { Female }\end{array}$ & Percent Youth & No-vehicle $\mathrm{HH}$ \\
\hline
\end{tabular}

Notes:

+: significantly positive relationship

-: significantly negative relationship

ns: no significant relationship was found

Blank cell means the variable was not included into the final model.

\subsubsection{Size of the buffer}

Most recent studies linking travel behavior and urban form characteristics measure the urban form for a defined area around the unit of analysis. For this research, the first level unit of analysis is the transit stop or station. The study area is usually described as a buffer of a certain distance from that point. Therefore, it is necessary to clarify the reasonable size of buffers for studying transit use. A reasonable approach links the size of the buffers to the distance that people are able and willing to access the transit service in a reasonable time. People generally access transit via walking, although both bicycle and automobile access are common. Thus, various reasonable distances may be generated for people with different modes of access, but usually for planning purposes, transit service is considered primarily to be accessed by walking (Foda and Osman 2010). It is suggested that destinations to which people can be expected to walk should be no further than a quarter mile distance (Ewing 1999), although some studies suggest that people will walk up to one mile for light rail transit (Agrawal 2008).

The 2009 National Household Travel Survey (NHTS) indicated that average time for people to get to public transit is 7.63 minutes, which is equivalent to 0.42 miles in walking, assuming an average walking speed of $3.16 \mathrm{mph}$. Given that some residents may be willing to walk slightly longer distances, while pedestrians with physical limitations, including many older adults, could only walk shorter distances, distances of a quarter mile and a half-mile may be reasonable for transit use studies.

For people without physical limitations, the distance for accessing bus and rail can be different, as people may be willing to walk further to access rail than bus due to the better level of service or longer travel distances. Based on surveys conducted in Calgary, Canada, Seneiratne (1985) found that over $80 \%$ of bus and light rail transit (LRT) users in Calgary walked less than 400 
meters ( 1/4 mile) and 600 meters respectively ( 1/3 mile) (Figure 2.1). O'Sullivan and Morrall (1996) studied the LRT system in Calgary, Canada, and suggested that walking distance guidelines for LRT should be different than bus, finding that people walk farther to reach an LRT station than a bus stop. Further, they suggested that design guidelines for LRT should be $700 \mathrm{~m}$ (0.4 miles) for local and transfer stations, $400 \mathrm{~m}$ for downtown offices, and $900 \mathrm{~m}$ for downtown residential developments ( $>1 / 2$ mile). Pulugurtha and Agurla (2012) assessed the bus ridership model using data for each buffer width $(0.25,0.5,0.75,1$ mile), and found that model developed using a quarter-mile buffer width had the best goodness-of-fit values.

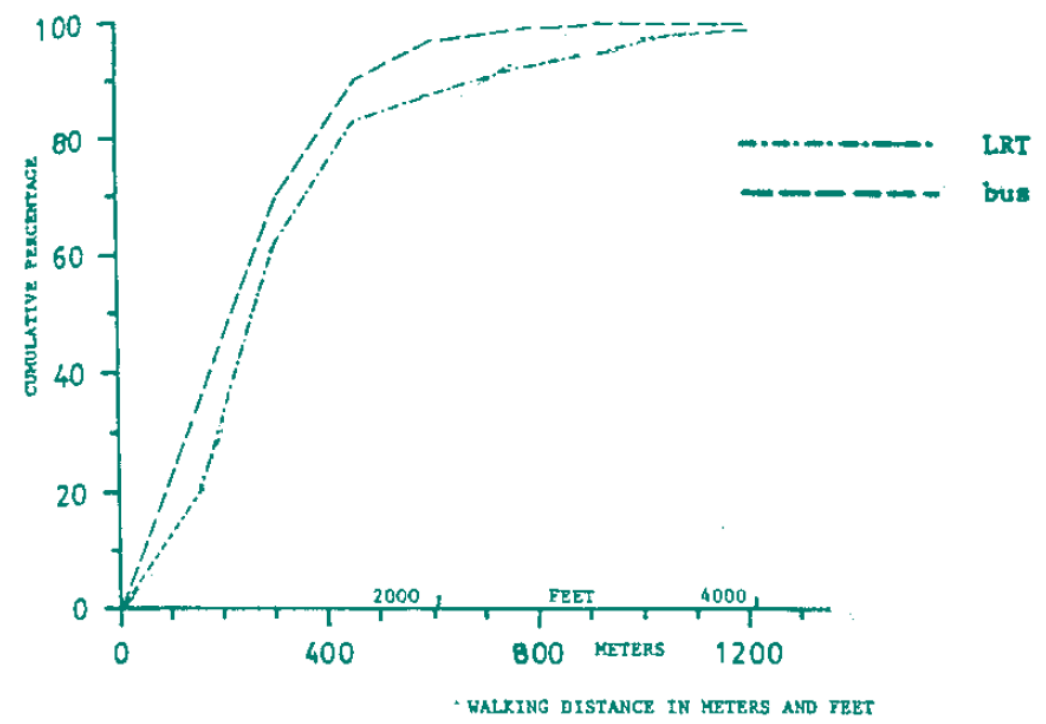

Source: Seneviratne, 1985

Figure 2.1 Cumulative Walking Distances to Bus and Light Rail Transit

The ways to create the buffer area can also be different based on the street network condition of the area. There are basically two ways to generate buffers: 1) straight-line buffers; and 2) network distance buffers. Straight-line buffers may be appropriate for an area with highly dense and connected street networks. However, in areas where the street network is not well connected, network distance buffers will more accurately reflect the walking distance people face to access transit. In practice, many previous studies employed the straight-line buffer for convenience. However, the simple straight-line buffer with a radius of access threshold around transit stop may overestimate the transit access coverage (Foda and Osman 2010).

Besides the traditional buffer analysis, there are other, more complicated, methods to define the transit service area. Kim et al. (2007) argued that using the quarter mile buffer as a transit service area was arbitrary, because this method assumed that transit demand falls from one to zero at exactly a one-quarter-mile distance. To address this concern, they developed a distance-decay function based on GIS to predict the transit demand.

Table 2.9 indicates the buffer sizes for the stop-based studies examined. Only one of the studies used a network buffer, while the distances ranged from 250 meters ( 0.15 miles) to one mile. 
Recent research comparing buffer sizes and their impact on regression results showed that using a quarter mile buffer yields accurate results (Pulugurtha and Agurla 2012).

Table 2.9: Transit ridership analysis unit at the stop or station level

\begin{tabular}{l|l|l}
\hline Sources & Transit Type & Buffer used \\
\hline Banerjee et al. 2005 & Rapid Bus & half mile and one mile circular buffer \\
\hline Cervero 2006 & Rail & Half mile \\
\hline Chu 2004 & Bus & quarter mile circular buffer \\
\hline Estupinan and Rodriguez 2008 & BRT & 250 meter circular buffer \\
\hline Lin and Shin 2008 & Metro & 500 meters circular buffer \\
\hline Pulugurtha and Agurla 2012 & $\begin{array}{l}\text { Bus Pulugurtha } \\
\text { and Agurla, 2012 }\end{array}$ & $0.25,0.5,0.75$, and 1 mile \\
\hline Ryan and Frank 2009 & Bus & half mile street network buffer \\
\hline Zhao et al. 2005 & Bus & quarter mile circular buffer \\
\hline
\end{tabular}

\subsubsection{Measuring the dependent variable}

A summary of dependent variables used for building the transit ridership models is shown in Table 2.10. These studies measured transit ridership by transit boardings and alightings in a typical day or year. Ryan and Frank (2009) used a summation of daily boardings and alightings to indicate daily transit demand, even though they pointed out the effects of built environment on transit ridership of trip origins (boardings) and destinations (alightings) might differ. Another potential problem with combining boardings and alightings is the potential high correlation between boarding at a stop and alighting at the stop on the opposite side of the route. Chu (2004) also pointed out that it was reasonable to expect that boardings and alightings would have different sets of predictors. Accessibility to jobs and people downstream of a stop is more relevant to boarding at that stop, for example, than to alighting at the opposite stop. Even though the potential problems, the significant relationship between total boardings and alightings and the built environment was found in several studies (Cervero 2006; Pulugurtha and Agurla 2012; Ryan and Frank 2009; Lin and Shin 2008; UNC 2006). Therefore, it may be appropriate to test the ridership models using boardings alone and total boardings and alightings as dependent variables respectively.

Table 2.10: Dependent Variables in Transit Ridership Models

\begin{tabular}{l|l}
\hline Source & Dependent Variables \\
\hline Banerjee et al. 2005 & Weekday boardings \\
\hline Cervero 2006 & Daily station boardings \\
\hline Chu 2004 & Weekday boardings \\
\hline Estupinan and Rodriguez 2008 & Number of daily boardings per station \\
\hline Lin and Shin 2008 & Daily passenger numbers entering and leaving a metro station \\
\hline Pulugurtha and Agurla 2012 & Average daily bus transit ridership at a bus stop \\
\hline Ryan and Frank 2009 & Daily bus boardings and alightings \\
\hline UNC 2006 & Total boardings and alightings in 2005 \\
\hline
\end{tabular}




\subsubsection{Form of the models}

In addition to selecting appropriate variables, the appropriate form of a model must be selected. A summary of methods used for estimating transit ridership models has been listed in Table 2.11.

This type of analysis requires some form of multivariate regression. However, because boardings and alightings are "count" data, and the distribution of count data can be skewed toward the origin, it is not always appropriate to employ the standard linear regression model which requires the assumption of normal distribution. Count data models, such as Poisson and Negative Binomial Regression models, are reasonable alternatives to construct the transit ridership model. For example, Chu (2004) and UNC (2006) employed Poisson and Negative Binomial regression respectively to build the stop-level bus ridership model. Besides, other approaches may also be applied in addressing the count data, for example, Ryan and Frank (2009) transformed the count data into logarithmic form. Pulugurtha and Agurla (2012) assessed the bus ridership model using four forms of models and found that Negative Binomial with log-link was a better fit than linear, Poisson with log-link, and Gamma with log-link models.

Another potential problem with transit ridership models is one of endogeneity. Most current models assumed that design measures (e.g. stop amenities), land use characteristics around the stop, and the level of service, is exogenous to transit demand. However, this may not be true when considering that many investments are placed at stops with high ridership to improve the amenities and service level of that stop. Therefore, transit demand could also determine the characteristics of the stop. In order to model the interaction between the transit demand and transit supply, Estupinan and Rodriguez (2008) employed a Two Stage Least Squares regression to account for the variation of BRT ridership in Bogota.

Table 2.11: Forms of Transit Ridership Models

\begin{tabular}{ll}
\hline Source & Model Form \\
\hline Banerjee et al. 2005 & Multiple Linear Regression \\
\hline Cervero 2006 & $\begin{array}{l}\text { Multiple Linear Regression with natural-log transformation of dependent } \\
\text { variable }\end{array}$ \\
\hline Chu 2004 & Poisson Regression \\
\hline Estupinan and Rodriguez 2008 & Two Stage Least Square Regression \\
\hline Lin and Shin 2008 & Multiple Linear Regression \\
\hline Pulugurtha and Agurla 2012 & Negative Binomial, Poisson, Gamma \\
\hline Ryan and Frank 2009 & Multiple Linear Regression with transformation of dependent variable \\
\hline UNC 2006 & Negative Binomial Regression \\
\hline
\end{tabular}

\subsection{OVERALL CONCLUSIONS}

Although there is wide consensus from MPOs and transit providers that performance should be tracked, there is little agreement on how various measures should be used (Hartman 1994). Determining the types of performance measures to use is dependent upon the outcomes and goals desired. This literature review reveals that there is a robust and mature field of performance measures based upon productivity from the transit agency's perspective, and quality of service from the rider's perspective. Measures from the community's perspective, such as measuring the accessibility to transit service, is limited. 
Stating the need to move beyond measuring transportation performance in terms of speed, which is primarily captured in the traditional "level of service” measurement, Reid Ewing suggests four options as suitable replacements: accessibility, mobility, livability, and sustainability. "Whereas levels of service relate to facilities, 'mobility' generally pertains to populations, 'accessibility' to land uses, 'livability' to communities, and 'sustainability' to developments” (Ewing 1995).

To align transit service performance measures with achieving livability goals, new measures will be required that combine the perspectives of the transit agency, the rider, and the community. "In the end, livability is not about transportation agencies or their land use and environmental partners: it is about residents” (Fabish 2010). To this end, transit performance measures have been moving from an agency-oriented to a rider-oriented focus over the last decade, however they have primarily focused upon the quality of services delivered. Performance measures based upon livability goals and community orientation are new approaches to help achieve increased ridership for transit agencies, with the least amount of overall travel time for passengers, while serving the land use goals of the community. This research project intends to fill in some of this existing knowledge gap. 


\subsection{METHODOLOGY}

\subsection{OVERVIEW}

There were three basic methodological components to this project: (1) the development of GISbased spatial indicators; (2) regression analysis linking those indicators with ridership data; and (3) evaluation of micro-scale urban design features. Indicators and analyses were based primarily at the transit stop level in order to connect ridership by stop with the urban form and destinations surrounding that stop. While transit service characteristics are important factors in an individual's decision to use transit, most transit users are pedestrians at the beginning and end of any transit trip. Therefore, focusing on the walkable zone around each transit stop is also important. That said, variables describing transit service characteristics, such as transfer centers and average headways by transit line, were also included.

Three metropolitan regions in Oregon were included in the analysis. The service areas of TriMet, Lane Transit District (LTD) and the Rogue Valley Transit Authority (RVTD) represent different types of communities. TriMet serves the largest (approximately 1.8 million population) metropolitan area in the state, Portland. LTD serves the medium-sized Eugene-Springfield area, with a population of about 250,000. RVTD is in the smaller urbanized area of Medford and Ashland, with a population about 150,000. In addition, there are very different built environment conditions within each metropolitan area. By focusing on stop-level ridership and their local built environment, this research can see how relationships between ridership and urban form may vary (or not) in different environments.

\subsection{GIS AND REGRESSION ANALYSIS}

\subsubsection{Regression Model Specification}

Multivariate linear regression was employed to estimate the relative effects of sociodemographics, land use, transportation infrastructure, and transit service characteristics in predicting transit ridership at each stop. Because boardings (getting on transit) and alightings (getting off transit) are "count" data, and the distribution of count data can be skewed toward the origin (zero), it is not reasonable to use ridership data directly as the dependent variable in linear model due to the violation of a major assumption of OLS. Therefore, a logarithm transformation of ridership data was conducted. We also tested count data models, such as Poisson and Negative Binomial Regression models. The results of these models were very similar to the results of the linear models using the logarithm transformation, and we did not find any advantages to use count data model to predict transit ridership in this case.

The final estimation model can be expressed as below:

$$
\operatorname{LnR}=\mathrm{c}+\sum \mathrm{a}_{0} \mathrm{X}_{\mathrm{r}}+\sum \mathrm{a}_{1} \mathrm{X}_{\mathrm{s}}+\sum \mathrm{a}_{2} \mathrm{X}_{\mathrm{t}}+\sum \mathrm{a}_{3} \mathrm{X}_{\mathrm{l}}+\varepsilon
$$


In the equation, $\mathrm{R}$ is the transit ridership; $\quad \mathrm{X}_{\mathrm{s}}$ indicates transit service characteristics, such as headway times, $\quad \mathrm{X}_{\mathrm{t}}$ indicates transportation infrastructure in the stop proximity area, such as street connectivity, and $X_{1}$ indicates land use characteristics of stop proximity area, such as population density, and $\quad \mathrm{X}_{\mathrm{r}}$ indicates socio-demographic information of residents around bus stops, such as age, education, income etc.; $\mathrm{a}_{1}, \mathrm{a}_{2}, \mathrm{a}_{3}$, and $\mathrm{a}_{0}$ are coefficients to be estimated; $\mathrm{c}$ is the model constant and $\varepsilon$ is the residual error.

We estimated separate models for each region. All the variables we created were entered into the model at the beginning, and different combinations of these variables were tested before we determined the final models based upon goodness-of-fit statistics (adjusted $\mathrm{R}^{2}$ ). We eliminated variables that were highly correlated with one another, as well as variables that were not significant in any of the models. However, for comparison purposes, if a variable was significant in one model, we kept it in the other models.

All of the independent variables we tested are summarized in Table 3.1, with some further explanations below. Some of these variables did not end up being used in the final models. Appendix 0 describes the technical steps for creation of the variables in GIS. With a few exceptions, all of the variable calculations were based on 2008 data and linked to ridership data based on a unique stop identifier (Stop ID) provided by each transit agency. Analysis software included ArcGIS 9.3 and SPSS 19.0 for Windows.

All data were parsed into a consistent stop-based spatial unit of analysis. Multiple sized "buffers" or "zones" around each transit stop were originally used for the stop-based spatial analysis to understand whether buffer size and type made a difference in the analysis. In both the TriMet and LTD areas, network and circular-based buffers at quarter-mile and half-mile distances were used around each stop. Network buffers differ from circular buffers in that they measure the distance away from each stop along the street network. The resulting polygon is often irregular-shaped due to the non-uniform street network pattern that the buffer is based upon, thereby encompassing some aspect of the urban form within the spatial unit of analysis. An extreme example of that is shown in Figure 3.1. After comparing the results across all four methods (circular and network buffers at both quarter- and half-mile distances), and with an eye toward keeping analysis approaches as simple as possible for easy replication, the research team settled on using quarter-mile circular buffers in the analysis of RVTD. In addition, one of the independent variables, street connectivity, is the spatial characteristic that makes the networkbased buffer different than a circular buffer. Therefore including both street connectivity and network buffers is somewhat repetitive. 


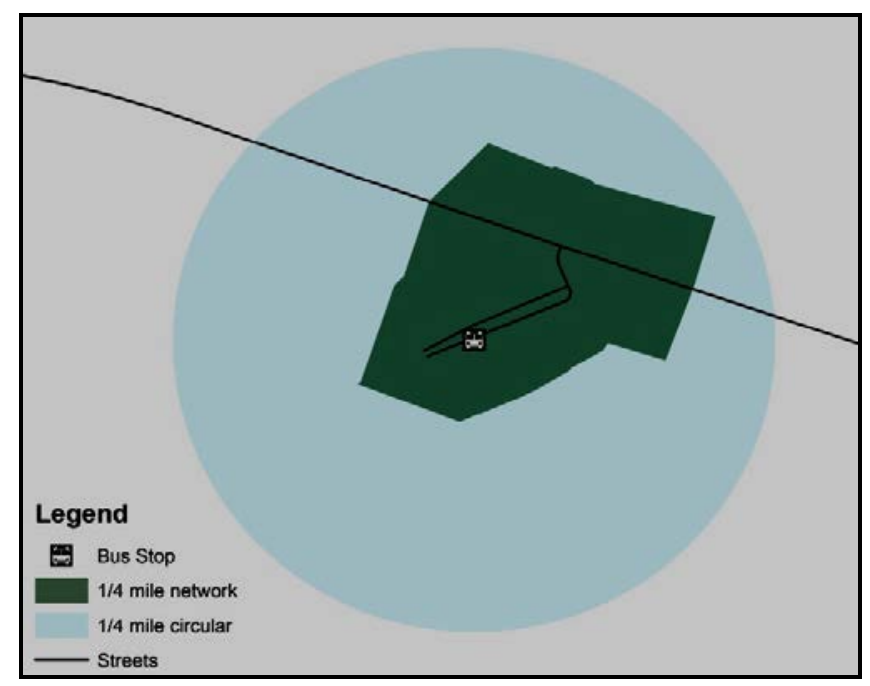

Figure 3.1: Comparing Network and Circular Buffers

\subsubsection{Transit Ridership (Dependent variable)}

TriMet collects ridership data using automated passenger counters on each bus or light rail car. These data are linked to stops via an automatic vehicle location (AVL) system. The data we used were from a three-month weekday average from Fall 2008. The primary interest of this study is about the relationship between livability and transit ridership, and both boarding and alighting can be associated with the design of station area. Therefore, we aggregated the total "ons" and total "offs" for each stop location to create the dependent ridership variable.

Ridership data for LTD was also collected using automatic counters, aggregating daily ridership for the week of Oct. 20 - 26, 2008. LTD collected the "Ons" and "Offs" by each transit route, by each scheduled time, and by each stop at each day within a week, we aggregated the whole "Ons" and "Offs" of the five weekdays respectively by transit stop ID, and then using the sums of "ons" and "offs" as the ridership for each stop.

RVTD's 2008 ridership data are based upon a hand-count. RVTD has since begun collecting data through an automatic counting system, but the research team wanted to use data across the three metropolitan areas from the same year. RVTD collected the ridership data by sampling transit trips for each transit route at different days from December 2007 to December 2008, and then aggregated the "Ons" and "Offs" during the sampling days by stop ID respectively. The daily ridership was calculated by dividing the aggregated ridership by number of sampling days.

As mentioned above, due to the skewed distribution of ridership data, we used logarithm form of ridership data as the dependent variable for models of both areas. Therefore, the interpretation of estimated coefficient should be the percentage change of ridership associated with one unit change of independent variable. 
Table 3.1: Independent Variable Details

\begin{tabular}{|c|c|c|}
\hline Variables & Unit or coding & Sources \\
\hline \multicolumn{3}{|l|}{ Socio-Demographic Variables } \\
\hline$\%$ of population female & percentage & \multirow{9}{*}{$\begin{array}{l}\text { US Census Bureau, } \\
\text { American Community } \\
\text { Survey 2005-2009 block } \\
\text { group data }\end{array}$} \\
\hline$\%$ of white population & percentage & \\
\hline \% of population with aged under 17 & percentage & \\
\hline$\%$ of population aged $18-25$ & percentage & \\
\hline$\%$ of population aged 65 or older & percentage & \\
\hline \% of population with college or above degree & percentage & \\
\hline$\%$ of households without vehicle available & percentage & \\
\hline Median family income & $\$ 000$ & \\
\hline \% of households with annual HH income below the poverty level & percentage & \\
\hline \multicolumn{3}{|l|}{ Transit Service Variables } \\
\hline Rail transit or BRT station (0=bus stop) (TriMet \& LTD only) & binary & \multirow{9}{*}{$\begin{array}{l}\text { GIS data from TriMet, } \\
\text { LTD, and RVTD }\end{array}$} \\
\hline Transfer Stop & binary & \\
\hline Transit Center & binary & \\
\hline Average headway & minutes & \\
\hline Maximum Coverage Time & minutes & \\
\hline Total bus stops (within buffer) & count & \\
\hline Total light rail stations (within buffer) (TriMet only) & count & \\
\hline Park \& Ride for Bus and LRT (or BRT) (TriMet \& LTD only) & count & \\
\hline Park \& Ride for bus only (TriMet only) & count & \\
\hline \multicolumn{3}{|l|}{ Transportation Infrastructure Variables } \\
\hline Street Connectivity (\# of street nodes with 3+ valence) & count & \multirow{3}{*}{$\begin{array}{l}\text { GIS data from Metro, } \\
\text { Lane Council of } \\
\text { Governments (LCOG), } \\
\text { and Jackson County }\end{array}$} \\
\hline Miles of regional multi-use paths (TriMet only) & mile & \\
\hline Miles of bike lanes & mile & \\
\hline \multicolumn{3}{|l|}{ Land Use Variables } \\
\hline Job Accessibility & $\begin{array}{l}\text { log-transform, } \\
\text { thousands }\end{array}$ & \multirow{2}{*}{$\begin{array}{l}\text { Oregon Employment } \\
\text { Department; LCOG; } \\
\text { Metro }\end{array}$} \\
\hline Total Employment (000) & thousand & \\
\hline Total Population (000) & thousand & US Census \\
\hline$\%$ of single family residential (SFR) land use & percentage & \multirow{4}{*}{$\begin{array}{l}\text { GIS data from Metro, } \\
\text { LCOG, and Jackson } \\
\text { County }\end{array}$} \\
\hline$\%$ of multi-family residential (MFR) land use & percentage & \\
\hline$\%$ of commercial (COM) land use & percentage & \\
\hline Total parks (area) & count & \\
\hline Pedestrian Destinations & count & $\begin{array}{l}\text { Oregon Employment } \\
\text { Department }\end{array}$ \\
\hline Land use mix index & n.a. & \multirow{3}{*}{$\begin{array}{l}\text { GIS data from Metro, } \\
\text { LCOG, and Jackson } \\
\text { County }\end{array}$} \\
\hline Downtown (PDX) or UO/SOU Campus (Lane/RVTD) & binary & \\
\hline Distance to city center & mile & \\
\hline
\end{tabular}

\subsubsection{Socio-Demographic Variables}

The socio-demographic makeup of each stop buffer area was obtained using available United States Census data from the 2005-2009 American Community Survey (ACS). ACS data from block groups around each stop buffer were compiled to determine the age, employment, gender, income, population, poverty, and race surrounding each transit stop. A proportional split methodology was used that assigns block group attributes at the same proportion of that block group that falls within the transit stop buffer area. For example, if $42 \%$ of the area of a block 
group falls within the stop's buffer, $42 \%$ of the block group’s population would be assigned to the stop area.

Age of the population was categorized by three groups: Under 17, 18-25, and 65 and older. Previous literature indicates that people at different age groups behave significantly different with respect to travel mode choice. For example, older adults may be inclined to take transit because it becomes difficult for them to drive. College-age adults may also be more attracted to transit. Income was represented in two variables: median household income and the percentage of households below poverty. In addition, vehicle availability (percentage of households without a vehicle) is sometimes used as a proxy for income.

\subsubsection{Transit Service Variables}

Transit service characteristics were measured in a variety of ways. Maximum coverage time (in minutes) is the difference in time between the first and last route of the day. However, for some routes there were large gaps of time without service. For example, some routes only operate during the peak commute times. If the gap was more than four hours, those gap times were eliminated from the coverage time. The coverage time was then used to calculate average headways - the number of minutes between each vehicle - for the route. If more than one route served a stop, the headway for most frequent route (the minimum headway) was assigned to the stop.

Each transit stop was also coded as to its transfer availability or the number of transfer opportunities between routes available at each stop. The presence of high capacity transit such as light rail or bus rapid transit (BRT) within each stop area was also noted.

We found that the Park \& Ride lots near transit stop or station have two types: Park \& Ride for bus users only and Park \& Ride for both bus and MAX light rail in Portland or for both regular bus and Bus Rapid Transit (BRT) in Lane County. It is necessary to differentiate them because they may have different effects on predicting ridership. There were no Park \& Ride lots in the RVTD area.

\subsubsection{Transportation Infrastructure Variables}

Given that transit users are often pedestrians at the beginning and/or end of their transit trip, the ability to navigate the local area by foot may be important if transit users are to easily get between the transit stop and their desired destination. Different street patterns may support or hinder pedestrian activity depending on path directness and the infrastructure that exists to support active transportation. Our measure of street connectivity counted the number of nodes with connections to three or more streets ("valences"). A node is defined as an intersection or the end of a street. This measure could be interpreted as the number of three- or more-way intersections within the buffer, or a measure of intersection density, since the buffers are consistent. Bicycling may be a complementary or competitive mode for transit. Bicycle infrastructure was measured as the miles of bike lanes and multi-use paths within the buffer. Multi-use paths are separated from the street and include access for pedestrians. Path data were only available for the TriMet area. 


\subsubsection{Land Use Variables}

Land use around a station generates both origins (e.g. home) and destinations (e.g. work) for potential transit trips. The land use variables tested in our models tried to reflect a variety of uses that could positively or negatively affect ridership. The data to create the land use variables came from either the U.S. Census (population), the area's planning agency (Metro, LCOG, or Jackson County), or the Oregon Employment Department. Employment data from Oregon Employment Department quarterly reports were geocoded to taxlots within the study areas. The data includes such information as salary, North American Industrial Classification System (NAICS Codes), and total number of employees. An improved 2008 dataset was available for both Lane and Metro, but not for Jackson County. The most important improvement in the data was the increased employment accuracy that resulted from employment data that was spatially disaggregated from a corporate headquarters to its regional outlets.

The variables for total employment and total population within the buffer act as density measures, since the circular buffer sizes are constant. Besides the total employment density, we created a variable to measure the low-income employment density. Low-income employment was defined as the employment whose average annual income is less than $\$ 15,000$, which is approximately the 20th percentile for Metro area and the 25th percentile for Lane County. We assumed that low-income employment is more dependent on public transit for daily commuting or other travel activities. In addition to the total number of jobs within the stop's buffer area, we measured job accessibility for each stop using the multi-modes network analysis tool in ArcGIS. The variable is defined as the total jobs that can be accessed by transit (plus walking) within 15 minutes. This measure is assumed to have a positive association with transit ridership.

We tested three other variables that might capture pedestrian destinations other than employment: commercial land use; land use mix; and pedestrian destinations. An entropy land use mix measure was created utilizing a variety of land use types, including commercial, multifamily, and single family housing land uses (see Appendix 0 for more detail). The number of "Pedestrian Destinations" within the buffer area was derived using the address or tax lot-based employment data. This was intended to provide a measure of pedestrian-oriented destinations in close proximity to each transit stop. The following destination categories were used in this measure:

- Convenience/small grocery store

- Gas station w/ convenience store

- Supermarket

- Hardware store

- Fruit/vegetable market

- Laundry/dry cleaners

- Clothing store

- Post office

- Elementary school

- Other schools

- Book store

- Fast food restaurant 
- Coffee place

- Bank/credit union

- Non-fast food restaurant

- Video store

- Pharmacy/drug store

- Salon/barber shop

- Recreation center

- Day Care

- Place of worship

- Senior Care Facility

- Medical/Dental

- Library

- Park

In addition to total population, residential land use was measured as the share of buffer area used for single-family or multi-family residential land uses.

To account for major destinations that might have more of a regional draw and characteristics not accounted for with the other land use variables, we created variables for downtown Portland (defined by the boundaries of the "Fareless Square") and the University of Oregon and Southern Oregon University campus areas. Stops were coded as either being within (1) or outside (0) these areas. In addition, for each region, the distance to downtown (Portland, Eugene, or Medford) was measured and used to reflect the relative position of each stop with the downtown employment center. We expected this to have a negative relationship with transit ridership because of the higher time cost for people living farther away from the city center.

\subsection{URBAN FORM EVALUATION}

In addition to the regression analyses, we conducted an evaluation focusing on design around several transit stops. The qualitative analysis looked at the facilities at actual transit stops as well as the contextual urban design of such stops relative to the surrounding pedestrian network and land use.

Stops to examine in the TriMet and LTD service areas were selected using the regression analysis results. We identified approximately forty stops that had unexpectedly high or unexpectedly low ridership for further investigation in two steps. The first step was to identify locations that were extreme in their location where further analysis would not be informative in any way. An example of such a location could be a transit stop at a lake boat ramp; both the location and the urban form of such an area would not provide generalizable insight. The second step was to take the remaining sites and investigate the patterns of development, location of stops, and the location and quality of the transportation networks surrounding each stop. 


\subsection{FINDINGS}

This section presents the findings from our GIS and regression analysis. We first present a descriptive analysis of the data, followed by the results from the regression models.

\subsection{DESCRIPTIVE ANALYSIS}

\subsubsection{Transit Ridership}

The average stop-level transit ridership for three regions is quite small. Over 50 percent of stops have fewer than 30 riders in a weekday, and over 70 percent of stops for Portland TriMet, over 90 percent for Lane Transit, and almost 90 percent for Rogue Valley Transit have a daily ridership less than 100 (Figure 4.1). Among the three regions, the average stop-level ridership for Portland (Table 4.1) is three times as high as the ridership for Lane (Table 4.2) and Rogue Valley (Table 4.3), while the Lane and Rogue Valley have the very similar average transit ridership per stop.

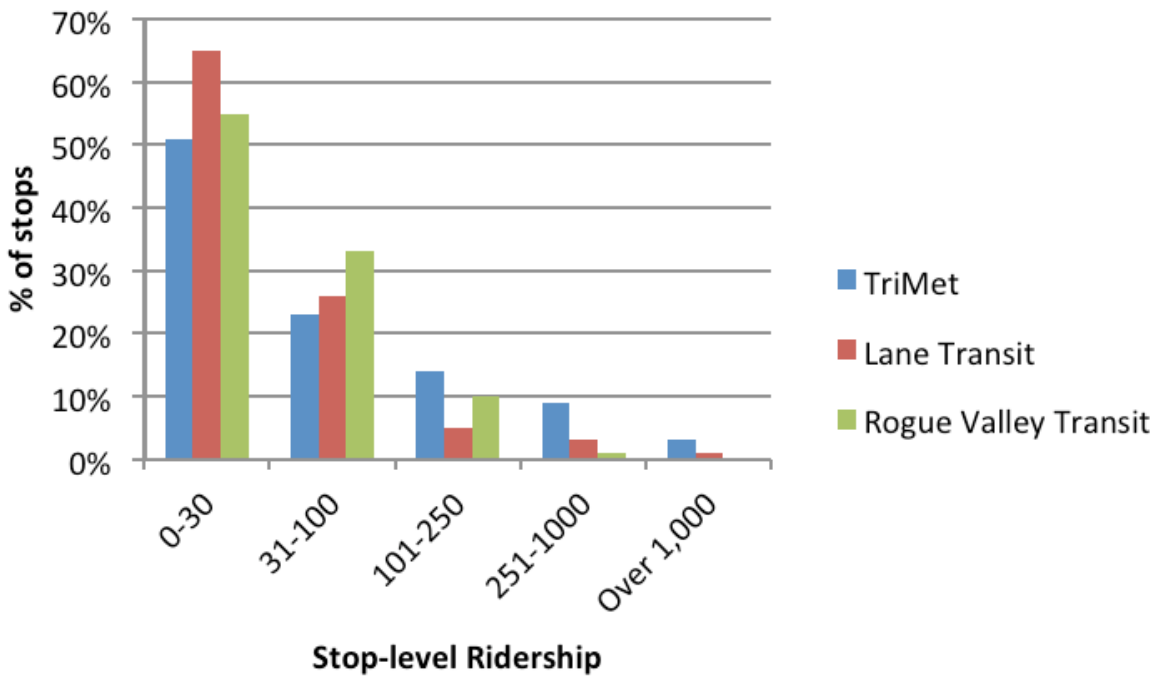

Figure 4.1: Average number of riders per stop in a typical weekday for the three regions

Figure 4.1 reveals the skewed distributions of ridership data for the three regions, which violate the normal distribution assumption of ordinary least square (OLS) regression. The logtransformed data looks close to normal (Figure 4.2, Figure 4.3, Figure 4.4), which is why it is used as the dependent variable in the regression models. 

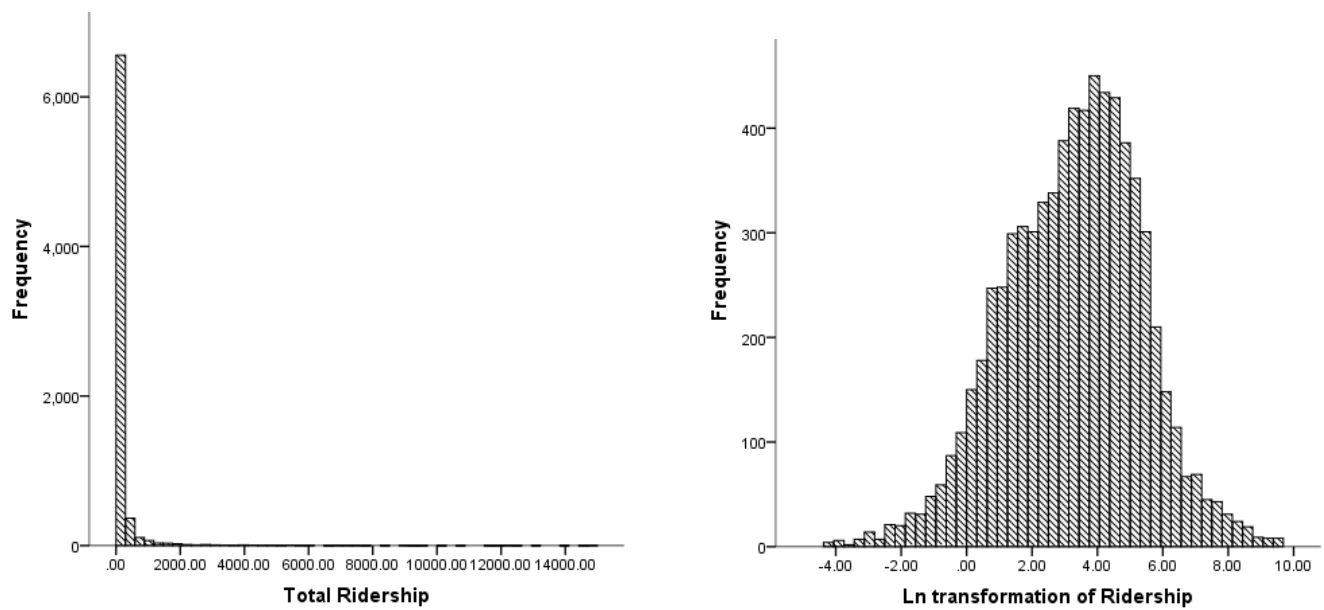

Figure 4.2 Distribution of ridership and log-transformed ridership, TriMet
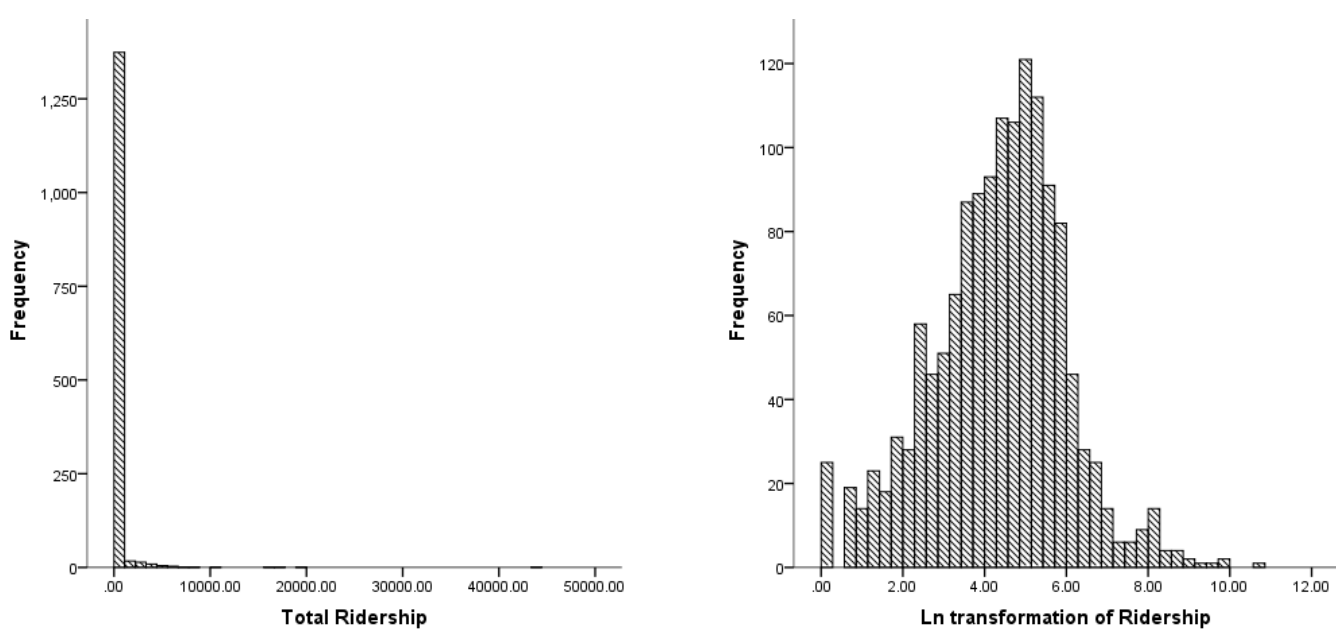

Figure 4.3 Distribution of ridership and log-transformed ridership, Lane Transit
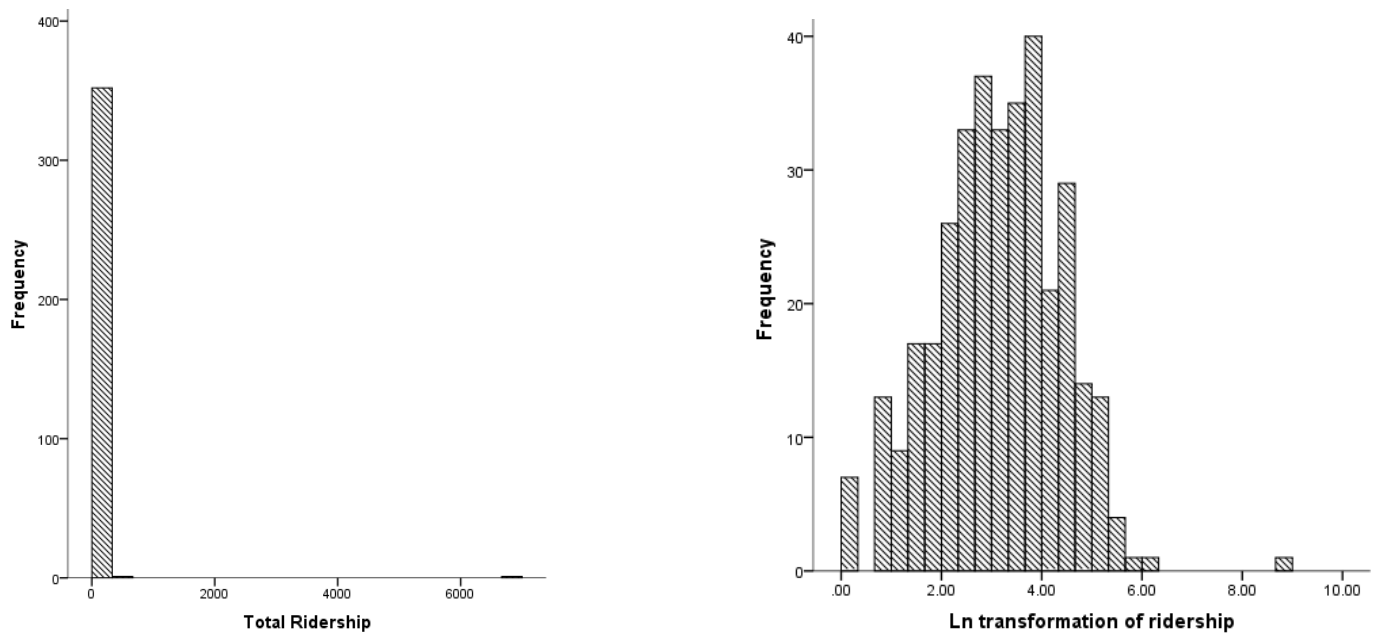

Figure 4.4 Distribution of ridership and log-transformed ridership, Rogue Valley 
Table 4.1 Descriptive Statistics for the Variables in TriMet Model

\begin{tabular}{|c|c|c|c|c|c|}
\hline Dependent Variables & $\mathbf{N}$ & Min. & Max. & Mean & $\begin{array}{l}\text { Std. } \\
\text { Dev. }\end{array}$ \\
\hline Total Riders & 7306 & 0 & 14,947 & 187 & 768 \\
\hline Log Transformation of Total Rider & 7214 & -4.4 & 9.6 & 3.3 & 2.1 \\
\hline \multicolumn{6}{|l|}{ Socio-Demographic Variables } \\
\hline$\%$ of female population & 7306 & $17 \%$ & $67 \%$ & $50.2 \%$ & $5 \%$ \\
\hline$\%$ of white population & 7306 & $37 \%$ & $100 \%$ & $81.1 \%$ & $11 \%$ \\
\hline \% of population below 17 & 7306 & $0 \%$ & $42 \%$ & $20.8 \%$ & $7 \%$ \\
\hline \% of population aged $18-25$ & 7306 & $1 \%$ & $62 \%$ & $9.0 \%$ & $5 \%$ \\
\hline$\%$ of population aged 65 or older & 7306 & $1 \%$ & $51 \%$ & $10.8 \%$ & $5 \%$ \\
\hline \% of population with college or above degree & 7306 & $2 \%$ & $69 \%$ & $26.7 \%$ & $15 \%$ \\
\hline Median Family Income (\$1000) annually & 7306 & 22.2 & 191.9 & 70.2 & 25.9 \\
\hline \% of households without vehicle available & 7306 & $0 \%$ & $88 \%$ & $10.5 \%$ & $11 \%$ \\
\hline \% of households with annual income below poverty & 7306 & $0 \%$ & $49 \%$ & $12.8 \%$ & $8 \%$ \\
\hline \multicolumn{6}{|l|}{ Transit Service Variables } \\
\hline Rail transit ( $0=$ bus stop) & 7306 & 0 & 1 & $1.6 \%$ & \\
\hline Transfer Stop & 7306 & 0 & 1 & $21.9 \%$ & \\
\hline Transit Center & 7306 & 0 & 1 & $1.3 \%$ & \\
\hline Average headway (minutes) & 7306 & 11 & 76 & 28 & 15 \\
\hline Maximum Coverage Time (minutes) & 7306 & 137 & 1,306 & 1,036 & 234 \\
\hline Total bus stops (within buffer) & 7306 & 1 & 256 & 16 & 21 \\
\hline Total light rail stations (within buffer) & 7306 & 0 & 16 & 0 & 1 \\
\hline Park \& Ride for Bus and LRT (or BRT) & 7306 & 0 & 1 & $0.4 \%$ & \\
\hline Park \& Ride for bus only & 7306 & 0 & 1 & $1.3 \%$ & \\
\hline \multicolumn{6}{|l|}{ Transportation Infrastructure Variables } \\
\hline Street Connectivity (\# of street nodes with 3+ valence) & 7306 & 0 & 97 & 30 & 17 \\
\hline Miles of regional multi-use paths & 7306 & 0 & 2.3 & 0.1 & 0.2 \\
\hline Miles of bike lanes & 7306 & 0 & 2.1 & 0.4 & 0.4 \\
\hline \multicolumn{6}{|l|}{ Land Use Variables } \\
\hline Job Accessibility (ln, 000) & 7306 & -5.3 & 5.5 & 3.3 & 1.2 \\
\hline Total Employment (000) & 7306 & 0 & 39.0 & 1.1 & 2.9 \\
\hline Total Population $(000)$ & 7306 & 0 & 4.3 & 1.0 & 0.5 \\
\hline$\%$ of SFR land use & 7306 & $0 \%$ & $85 \%$ & $35.9 \%$ & $22 \%$ \\
\hline$\%$ of MFR land use & 7306 & $0 \%$ & $54 \%$ & $5.6 \%$ & $7 \%$ \\
\hline$\%$ of COM land use & 7306 & $0 \%$ & $99 \%$ & $15.1 \%$ & $15 \%$ \\
\hline Total parks (area) & 7306 & 0 & 17 & 1 & 2 \\
\hline Pedestrian Destinations & 7306 & 0 & 255 & 10 & 19 \\
\hline Land use mix index & 7306 & 0 & 0.9 & 0.4 & 0.1 \\
\hline Downtown (PDX) & 7306 & 0 & 1 & $1.9 \%$ & \\
\hline Distance to center (miles) & 7306 & 0 & 30.6 & 8.6 & 4.5 \\
\hline
\end{tabular}


Table 4.2 Descriptive Analysis for the Variables in Lane Transit Model

\begin{tabular}{|c|c|c|c|c|c|}
\hline & $\mathbf{N}$ & Min. & Max. & Mean & $\begin{array}{l}\text { Std. } \\
\text { Dev. }\end{array}$ \\
\hline \multicolumn{6}{|l|}{ Dependent Variables } \\
\hline Total Riders & 1429 & 1 & 43,530 & 324 & 1,562 \\
\hline Log Transformation of Total Rider & 1429 & 0 & 10.7 & 4.3 & 1.6 \\
\hline \multicolumn{6}{|l|}{ Socio-Demographic Variables } \\
\hline$\%$ of female population & 1403 & $27 \%$ & $63 \%$ & $50.8 \%$ & $5 \%$ \\
\hline$\%$ of white population & 1403 & $60 \%$ & $100 \%$ & $87.4 \%$ & $7 \%$ \\
\hline$\%$ of population below 17 & 1403 & $0 \%$ & $38 \%$ & $18.9 \%$ & $8 \%$ \\
\hline \% of population aged $18-25$ & 1403 & $1 \%$ & $95 \%$ & $18.3 \%$ & $16 \%$ \\
\hline$\%$ of population aged 65 or older & 1403 & $0 \%$ & $44 \%$ & $12.9 \%$ & $7 \%$ \\
\hline$\%$ of population with college or above degree & 1403 & $1 \%$ & $50 \%$ & $19.3 \%$ & $11 \%$ \\
\hline Median Family Income (\$1000) annually & 1403 & 12.3 & 138.2 & 55.2 & 16.8 \\
\hline \% of households without vehicle available & 1403 & $0 \%$ & $59 \%$ & $11.4 \%$ & $11 \%$ \\
\hline \% of households with annual income below poverty & 1403 & $0 \%$ & $84 \%$ & $21.0 \%$ & $15 \%$ \\
\hline \multicolumn{6}{|l|}{ Transit Service Variables } \\
\hline BRT station ( $0=$ bus stop) & 1433 & 0 & 1 & $0.7 \%$ & \\
\hline Transfer Stop & 1400 & 0 & 1 & $53.9 \%$ & \\
\hline Transit Center & 1400 & 0 & 1 & $2.9 \%$ & \\
\hline Average headway (minutes) & 1400 & 12 & 95 & 36 & 18 \\
\hline Maximum Coverage Time (minutes) & 1400 & 16 & 1,079 & 818 & 287 \\
\hline Total bus stops (within buffer) & 1403 & 1 & 42 & 8 & 6 \\
\hline Park \& Ride & 1403 & 0 & 1 & $12.3 \%$ & \\
\hline \multicolumn{6}{|l|}{ Transportation Infrastructure Variables } \\
\hline Street Connectivity (\# of street nodes with 3+ valence) & 1403 & 0 & 111 & 32 & 23 \\
\hline Miles of bike lanes & 1403 & 0 & 2.3 & 0.5 & 0.5 \\
\hline \multicolumn{6}{|l|}{ Land Use Variables } \\
\hline Job Accessibility (000) & 1405 & 0 & 53,680 & 16,044 & 16,232 \\
\hline Total Employment (000) & 1403 & 0 & 8.8 & 0.8 & 1.4 \\
\hline Total Population (000) & 1403 & 0 & 3.5 & 0.8 & 0.5 \\
\hline$\%$ of SFR land use & 1405 & $0 \%$ & $90 \%$ & $34.9 \%$ & $23 \%$ \\
\hline$\%$ of MFR land use & 1405 & $0 \%$ & $52 \%$ & $4.3 \%$ & $6 \%$ \\
\hline$\%$ of COM land use & 1405 & $0 \%$ & $86 \%$ & $15.3 \%$ & $16 \%$ \\
\hline Total parks (area) & 1403 & 0 & 5 & 1 & 1 \\
\hline Pedestrian Destinations & 1403 & 0 & 91 & 9 & 14 \\
\hline Land use mix index & 1405 & 0 & 0.7 & 0.4 & 0.1 \\
\hline UO Campus & 1433 & 0 & 1 & $5.1 \%$ & \\
\hline Distance to center (miles) & 1405 & 0 & 49.3 & 4.6 & 6.4 \\
\hline
\end{tabular}


Table 4.3 Descriptive analysis for the variables in Rogue Valley Model

\begin{tabular}{|c|c|c|c|c|c|}
\hline & $\mathbf{N}$ & Min. & Max. & Mean & $\begin{array}{l}\text { Std. } \\
\text { Dev. }\end{array}$ \\
\hline \multicolumn{6}{|l|}{ Dependent Variable } \\
\hline Total riders & 354 & 0 & 6,737 & 62.22 & 359.91 \\
\hline Log Transformation of Total Rider & 351 & 0 & 8.8 & 3.1 & 1.3 \\
\hline \multicolumn{6}{|l|}{ Socio-Demographic Variables } \\
\hline$\%$ of female population & 359 & $5 \%$ & $60 \%$ & $51.1 \%$ & $6 \%$ \\
\hline \% of white population & 359 & $70 \%$ & $98 \%$ & $91.4 \%$ & $5 \%$ \\
\hline$\%$ of population below 17 & 359 & $0 \%$ & $42 \%$ & $21.4 \%$ & $7 \%$ \\
\hline \% of population aged $18-25$ & 359 & $0 \%$ & $48 \%$ & $10.6 \%$ & $6 \%$ \\
\hline$\%$ of population aged 65 or older & 359 & $4 \%$ & $41 \%$ & $15.0 \%$ & $7 \%$ \\
\hline$\%$ of population with college or above degree & 359 & $0 \%$ & $36 \%$ & $13.1 \%$ & $8 \%$ \\
\hline Median Family Income (\$1000) annually & 359 & 18.1 & 90.5 & 47.7 & 11.5 \\
\hline \% of households without vehicle available & 359 & $0 \%$ & $35 \%$ & $8.9 \%$ & $7 \%$ \\
\hline \% of households with annual income below poverty & 359 & $0 \%$ & $46 \%$ & $16.8 \%$ & $9 \%$ \\
\hline \multicolumn{6}{|l|}{ Transit Service Variables } \\
\hline Transfer Stop & 359 & 0 & 1 & $3.3 \%$ & \\
\hline Transit Center & 359 & 0 & 1 & $0.3 \%$ & \\
\hline Average headway (minutes) & 359 & 30 & 60 & 34 & 9 \\
\hline Maximum Coverage Time (minutes) & 359 & 630 & 810 & 766 & 62 \\
\hline Total bus stops (within buffer) & 359 & 1 & 11 & 5 & 2 \\
\hline Park \& Ride & 359 & 0 & 1 & $2.2 \%$ & \\
\hline \multicolumn{6}{|l|}{ Transportation Infrastructure Variables } \\
\hline Street Connectivity (\# of street nodes with 3+ valence) & 359 & 0 & 55 & 21 & 14 \\
\hline Miles of bike lanes & 359 & 0.0 & 1.3 & 0.3 & 0.3 \\
\hline \multicolumn{6}{|l|}{ Land Use Variables } \\
\hline Job Accessibility (ln, 000) & 359 & -3.4 & 3.2 & 1.7 & 1.0 \\
\hline Total Employment (000) & 359 & 0 & 5.1 & 0.6 & 0.7 \\
\hline Total Population (000) & 359 & 0 & 1.8 & 0.6 & 0.4 \\
\hline$\%$ of SFR land use & 359 & $4 \%$ & $115 \%$ & $43 \%$ & $21 \%$ \\
\hline$\%$ of MFR land use & 359 & $0 \%$ & $33 \%$ & $7 \%$ & $6 \%$ \\
\hline$\%$ of COM land use & 359 & $0 \%$ & $98 \%$ & $20 \%$ & $18 \%$ \\
\hline Total parks (area) & 359 & 0 & 6 & 1 & 1 \\
\hline Pedestrian Destinations & 359 & 0 & 91 & 12 & 14 \\
\hline Land use mix index & 359 & 0 & 0.8 & 0.5 & 0.1 \\
\hline Southern Oregon University Campus & 359 & 0 & 1 & $1.7 \%$ & $12.8 \%$ \\
\hline Distance to center (miles) & 359 & 0 & 14.7 & 4.6 & 4.1 \\
\hline
\end{tabular}

\subsubsection{Socio-demographic Variables}

The quarter-mile area around the average TriMet stop had the following population characteristics: 81 percent white, 21 percent children under 17, 11 percent older adults (65+), and 27 percent held college degrees. The average median family income was $\$ 70,000$ per year, 11 percent of households did not own a vehicle, and 13 percent households lived under the national poverty level (Table 4.1).

Demographics were similar around LTD stops, which averaged 87 percent white, 19 percent children under 17, 13 percent older adults (65+), and 19 percent held college degrees (Table 4.2). The level of college education is likely lower because of the large share of the population being 
students attending the University of Oregon. The average median family income was lower than in the Portland region $(455,000)$ and the share of households below poverty was higher (21 percent). Eleven percent households did not own a vehicle.

Among the population living at transit stop proximity areas in Rogue Valley, approximately 51 percent were female, 91 percent were white, 21 percent were children, 15 percent were older people and 13 percent held college or above degree. For the households located at stop proximity areas, the median family income was 48 thousand dollars per year, 9 percent households did not own a vehicle, and 17 percent households lived under the national poverty level (Table 4.3).

\subsubsection{Transit Service Variables}

For Portland Metro, 1.6 percent of the 7,306 stops analyzed were light rail transit stations, and 1.3 percent were designated transit centers. . The TriMet transit service network is extensive and well-connected (Figure 4.5), resulting in 22 percent of the stops being transfer stops. The average headway for the stops was 28 minutes (ranging from 11 to 76 minutes), and the average coverage time was 1036 minutes (17 hours). Within the quarter mile buffer area of a transit stop, there were an average of 16 bus stops, and less than one rail transit station. On average, 1.7 percent of transit stop/stations had Park \& Ride lots (Table 4.1).

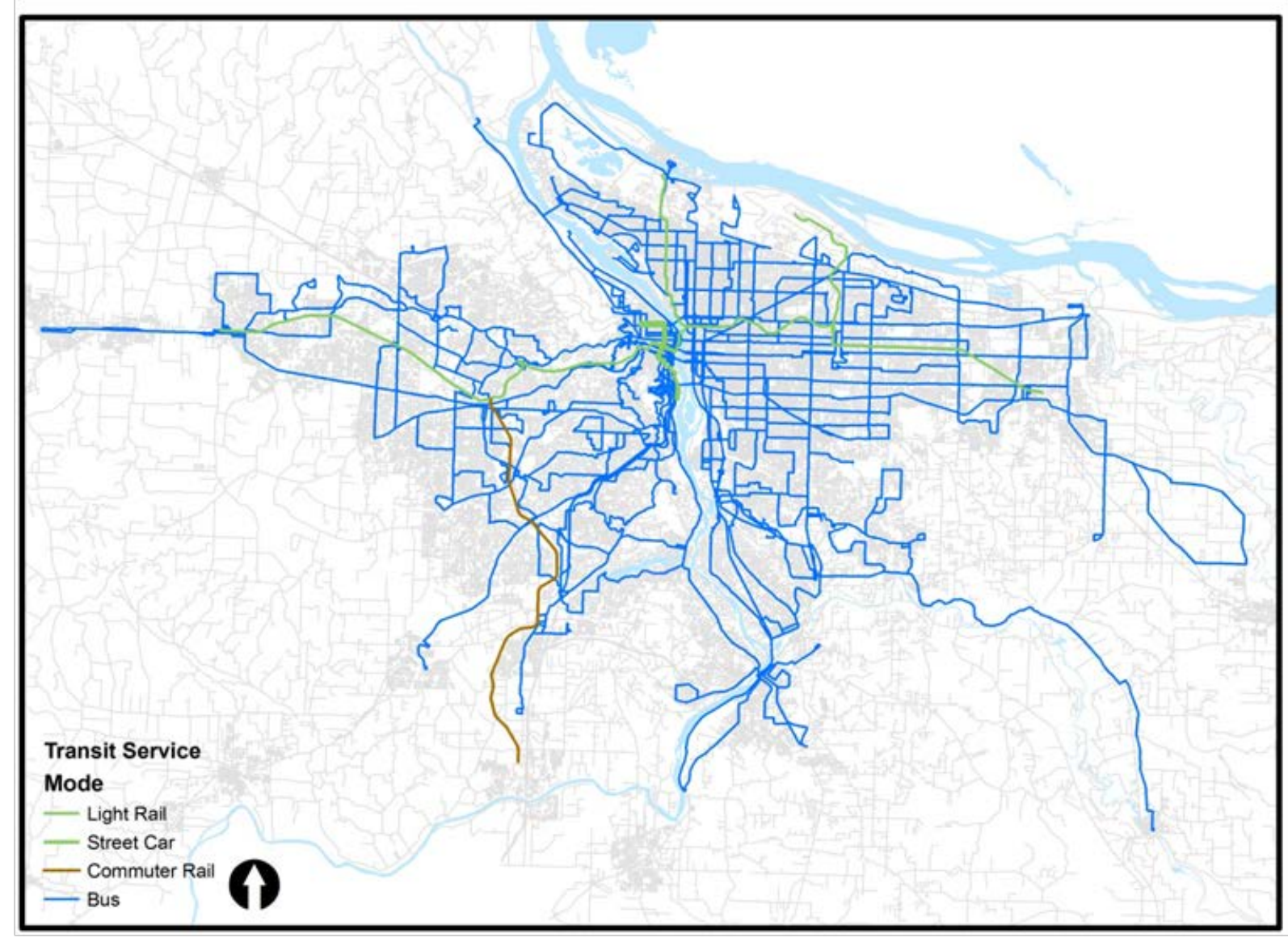

Figure 4.5: TriMet Transit Service 
For Lane Transit (Figure 4.6), only 0.7 percent of public transit service was provided by bus rapid transit (10 BRT stations vs. 1,423 bus stops). Among all the stops, 54 percent were transfer stops and 3 percent were transit centers. The average headway for the stops was 36 minutes (ranging from 12 to 95 minutes), and the average coverage time was 818 minutes (14 hours). Within the quarter mile buffer area of a transit stop/station, there were an average of 8 bus stops. On average, 12 percent of transit stop/stations had Park \& Ride lots (Table 4.2).

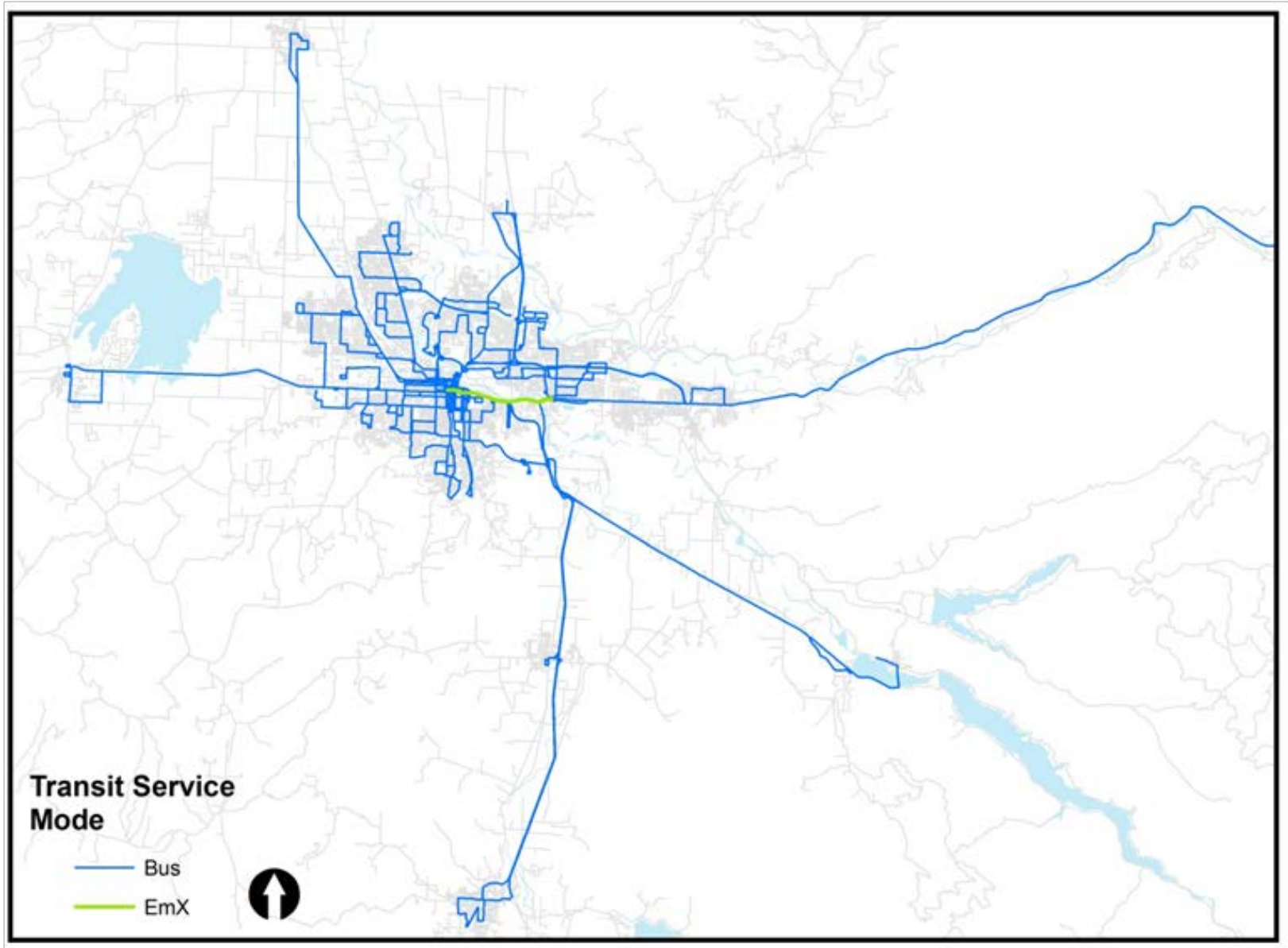

Figure 4.6: Lane Transit Service

The Rogue Valley Transit system is much smaller (Figure 4.7), with on 359 bus stops; there is no rail or BRT system. Among all the bus stops, only 3.3 percent were transfer stops and only one is considered a transit center. This indicates a much smaller, simpler system. The average headway for the bus stops was 34 minutes (ranging from 30 to 60 minutes), and the average coverage time was 766 minutes (13 hours). Within the quarter mile buffer area of a transit stop/station, there were an average of 5 bus stops. On average, 2.2 percent of transit stop/stations had Park \& Ride lots (Table 4.3). 


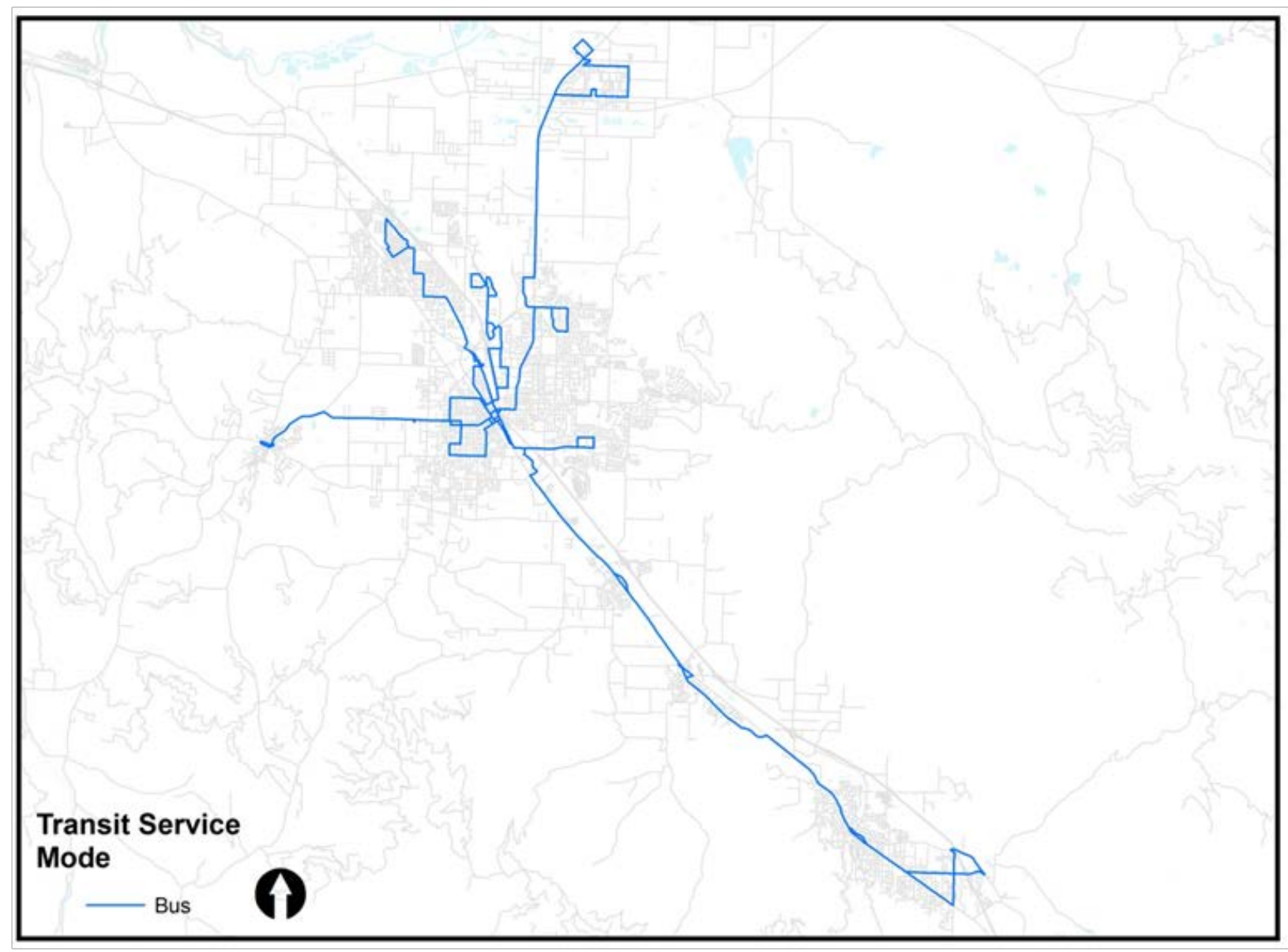

Figure 4.7: Rogue Valley Transit Service

\subsubsection{Transportation Infrastructure Variables}

Within each of the transit stop/station proximity areas in Portland, there were an average of 30 3+-way intersections, 0.1 miles of regional multi-use paths, and 0.4 miles of bike lanes. This is comparable to Lane County, with an average of 32 3+-way intersections, and 0.5 miles of bike lanes. The street system around RVTD bus stops was less connected, averaging 21 3+-way intersections, and had an average of 0.3 miles of bike lanes.

\subsubsection{Land Use Variables}

As would be expected, job accessibility is highest around and from stops in the TriMet area. The average TriMet stop has about 1,100 jobs within a quarter mile circular buffer and 27,000 jobs can be accessed within 15 minutes. This compares to an average of about 750 jobs around LTD stops and 628 jobs around RVTD stops. Job accessibility (15 minutes) from LTD stops averaged 16,000 and from RVTD stops 8,600. Similarly, population was higher around TriMet stops, averaging about 1,000 people, compared to 800 for LTD and 600 for RVTD. Note that these averages are within wide ranges (see Table 4.1, Table 4.2, and Table 4.3) 
In the Portland region, among the different land use types around the transit stop/stations, approximately 36 percent, on average, was single family housing, 6 percent was multi-family housing, and 15 percent was commercial. On average, there was one park, and 10 pedestrian destinations (e.g. shops, restaurants, banks, post offices, schools, etc.) close to each of the transit stop/station. The number of pedestrian destinations ranged from zero to 255. The average land use mix index around each transit stop/station was 0.4, ranging from about zero to 0.9. About 2 percent of the transit stops/stations were located in the Portland downtown area and the average distance to urban center (i.e. city hall) from each transit stop/station was 8.6 miles.

For LTD, some of the average land use characteristics were similar. Approximately 35 percent of the area around the stations, on average, was single-family housing, 4 percent was multi-family housing, and 15 percent was commercial. On average, there was one park, and 9 pedestrian destinations (e.g. shops, restaurants, banks, post offices, schools, etc.) close to each of the transit stop/station. The maximum number of destinations was much lower than in Portland -91 . The average land use mix index around each transit stop/station was 0.4. About 5 percent of the stops were located in the University of Oregon campus area, and the average distance to the urban center (i.e. city hall) from each transit stop/station was 4.6 miles.

For RVTD, among the different land use types around the bus stops, approximately 43 percent was single-family housing, 7 percent was multi-family housing, and 20 percent was commercial. On average, there was one park, and 12 pedestrian destinations (e.g. shops, restaurants, banks, post offices, schools, etc.) close to each of the transit stop/station. The average land use mix index around each transit stop/station was 0.5 . Around 2 percent of the stops were located in the Southern Oregon University campus area, and the average distance to urban center (i.e. city hall) from each transit stop/station was 4.6 miles (Table 4.3).

\subsection{MODEL RESULTS}

The final model results for TriMet, LTD and RVTD are summarized in Table 4.4 and shown in detail in Table 4.5. The TriMet model does the best job explaining the variation in ridership at the stop-level; the adjusted-R2 is 0.69 , indicating that the independent variables explain $69 \%$ of the variance in the dependent variable. The adjusted-R2 for the LTD and RVTD model are 0.62 and 0.53 respectively. As noted in the methods section, the dependent variable for all models is a logarithmic form of ridership data. Therefore, the estimated coefficients should be interpreted as the percentage change in ridership associated with one unit change in the independent variable. In addition, after developing the final models, we entered the variables into each model in groups (socio-demographic, transit service, transportation infrastructure, and urban land use) to estimate the relative contribution of each of those sets of characteristics (Table 4,4). As expected, qualities of the transit service, e.g. headways and type of transit, are the most important factors in determining ridership at the stop level. For the Portland region (TriMet) and Lane County (LTD), socio-demographic factors are second in importance, followed by land use variables. For Rogue Valley (RVTD), land use variables explain more than the socio-demographic variables. The discussion below discusses the statistically significant variables, including differences among the three models. 
Table 4.4: Contribution of Variables to Overall Model Explanatory Power

\begin{tabular}{llll}
\hline & Portland (TriMet) & $\begin{array}{l}\text { Lane County } \\
\text { (LTD) }\end{array}$ & $\begin{array}{l}\text { Rogue Valley } \\
\text { (RVTD) }\end{array}$ \\
\hline Adjusted R2 & 0.69 & 0.62 & 0.53 \\
\hline Socio-Demographic Variables & $24 \%$ & $11 \%$ & $11 \%$ \\
\hline Transit Service Variables & $41 \%$ & $46 \%$ & $27 \%$ \\
\hline Transportation Infrastructure Variables & $1 \%$ & $1 \%$ & $1 \%$ \\
\hline Land Use Variables & $4 \%$ & $5 \%$ & $17 \%$ \\
\hline Unexplained by the model & $31 \%$ & $38 \%$ & $47 \%$ \\
\hline $\begin{array}{l}\text { Note: The contribution of the variables as a group to the overall model is estimated using the change in the adjusted } \mathrm{R}^{2} \text { after each group of } \\
\text { variables is entered into the model, starting with socio-demographic variables. The percentages do not add up to the final adjusted R }{ }^{2} \text { due to } \\
\text { rounding. }\end{array}$
\end{tabular}

Table 4.5: Model Results

\begin{tabular}{|c|c|c|c|c|c|c|}
\hline & \multicolumn{2}{|c|}{$\begin{array}{l}\text { Portland } \\
\text { (TriMet) }\end{array}$} & \multicolumn{2}{|c|}{$\begin{array}{l}\text { Lane County } \\
\text { (LTD) }\end{array}$} & \multicolumn{2}{|c|}{$\begin{array}{l}\text { Rogue Valley } \\
\text { (RVTD) }\end{array}$} \\
\hline & Coeff. & $\mathbf{p}$ & Coeff. & $\mathbf{p}$ & Coeff. & $\mathbf{p}$ \\
\hline \multicolumn{7}{|l|}{ Socio-Demographic Variables } \\
\hline$\%$ of white population & -1.163 & .00 & -.329 & .54 & -.053 & .97 \\
\hline$\%$ of population with aged under 17 & .662 & .03 & 1.232 & .05 & -.661 & .51 \\
\hline$\%$ of population aged 65 or older & .058 & .85 & -2.515 & .00 & 3.709 & .00 \\
\hline$\%$ of population with college or above degree & -.799 & .00 & -.242 & .49 & -1.378 & .25 \\
\hline$\%$ of households without vehicle available & -.788 & .00 & -1.256 & .02 & -4.511 & .01 \\
\hline $\begin{array}{l}\% \text { of households with annual HH income below the } \\
\text { poverty level }\end{array}$ & .920 & .00 & .027 & .95 & 2.369 & .07 \\
\hline \multicolumn{7}{|l|}{ Transit Service Variables } \\
\hline Rail transit or BRT station ( $0=$ bus stop) & 2.814 & .00 & 1.978 & .00 & & \\
\hline Transfer Stop & .577 & .00 & .166 & .01 & .249 & .51 \\
\hline Transit Center & 2.297 & .00 & 2.849 & .00 & 3.946 & .00 \\
\hline Average headway (minutes) & -.041 & .00 & -.025 & .00 & -.051 & .00 \\
\hline Maximum Coverage Time (minutes) & .003 & .00 & .002 & .00 & .038 & .69 \\
\hline Total bus stops (within buffer) & -.012 & .00 & -.020 & .02 & -.098 & .00 \\
\hline Total light rail stations (within buffer) & -.239 & .00 & & & & \\
\hline Park \& Ride for Bus and LRT (or BRT) & .944 & .00 & .458 & .00 & 1.331 & .00 \\
\hline Park \& Ride for bus only & .328 & .01 & & & & \\
\hline \multicolumn{7}{|l|}{ Transportation Infrastructure Variables } \\
\hline Street Connectivity & .020 & .00 & .008 & .00 & .009 & .19 \\
\hline Miles of regional multi-use paths & .300 & .00 & & & & \\
\hline Miles of bike lanes & .182 & .00 & -.085 & .33 & .377 & .03 \\
\hline \multicolumn{7}{|l|}{ Land Use Variables } \\
\hline Job Accessibility (natural log, 000) & .057 & .00 & .009 & .01 & .185 & .04 \\
\hline Total Employment (000) & .091 & .00 & -.054 & .24 & .051 & .67 \\
\hline Total Population (000) & .303 & .00 & -.174 & .13 & .844 & .00 \\
\hline$\%$ of SFR land use & .099 & .36 & .322 & .15 & -1.060 & .13 \\
\hline$\%$ of MFR land use & 2.339 & .00 & 4.201 & .00 & 3.271 & .00 \\
\hline
\end{tabular}




\begin{tabular}{lllllll} 
\% of COM land use & 1.882 & .00 & .459 & .15 & 2.149 & .00 \\
\hline Total parks (area) & -.031 & .00 & -.054 & .04 & .025 & .63 \\
\hline Pedestrian destinations & .013 & .00 & .022 & .00 & .013 & .04 \\
\hline Land use mix index & .160 & .12 & .592 & .04 & -.558 & .31 \\
\hline $\begin{array}{l}\text { Stop located: (1) in downtown Portland; (2) near Univ. } \\
\text { of Oregon; (3) near So. Oregon Univ. }\end{array}$ & .921 & .00 & -.197 & .32 & -.030 & .96 \\
\hline Distance to city center (miles) & -.017 & .01 & .033 & .00 & .069 & .01 \\
\hline Model Statistics & & & & & & \\
\hline Adjusted R2 & .69 & .62 & & \\
\hline $\mathrm{N}$ & 7214 & 1400 & & \\
\hline
\end{tabular}

\subsubsection{Socio-Demographic Variables}

The socio-demographic variables explain about $24 \%$ of the variance in the TriMet model and $11 \%$ in both LTD and RVTD models. The sign, magnitude and significance level of the coefficients for socio-demographic variables among the three models do share several similar characteristics but differences exist as well. Within the Portland area, three demographic variables had a significant negative effect on ridership: the share of the population that was white, was college-educated, and did not have a vehicle. The first two are consistent with other research; transit riders are more likely to be non-white and lower-educated. These variables were not significant in the LTD or RVTD models, though the signs of the coefficients were consistent. For race, this may be due to the relative lack of diversity in those two areas. The distribution of stops with for this variable is shown in Figure 4.8, which shows that $79 \%$ of the stops in Rogue Valley have a population that is at least $90 \%$ white. In contrast, for the Portland region only $23 \%$ of the stops have a similar lack of diversity. While Lane County is more diverse than Rogue, for nearly $90 \%$ of the stops at least $80 \%$ of the surrounding population is white. Similarly, there is a wider distribution with respect to the share of the population around stops having a college degree in the TriMet service area than for LTD and, in particular, RVTD (Figure 4.9). 


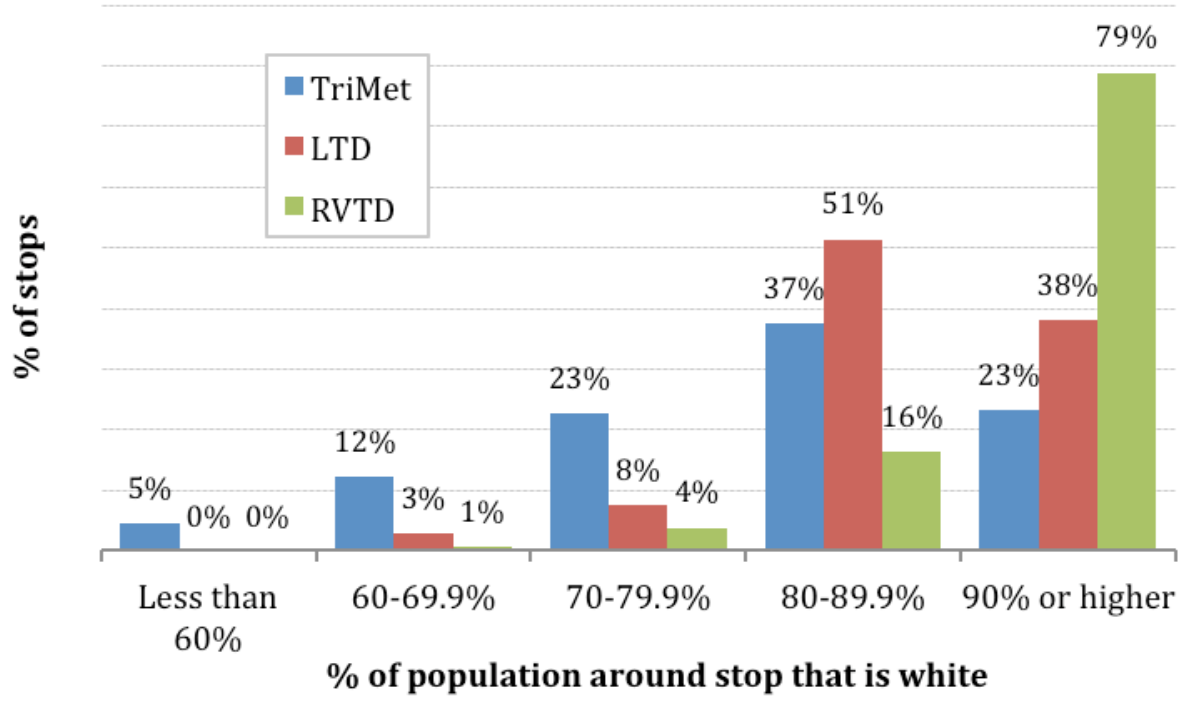

Figure 4.8: Distribution of Stops and \% of Population that is White

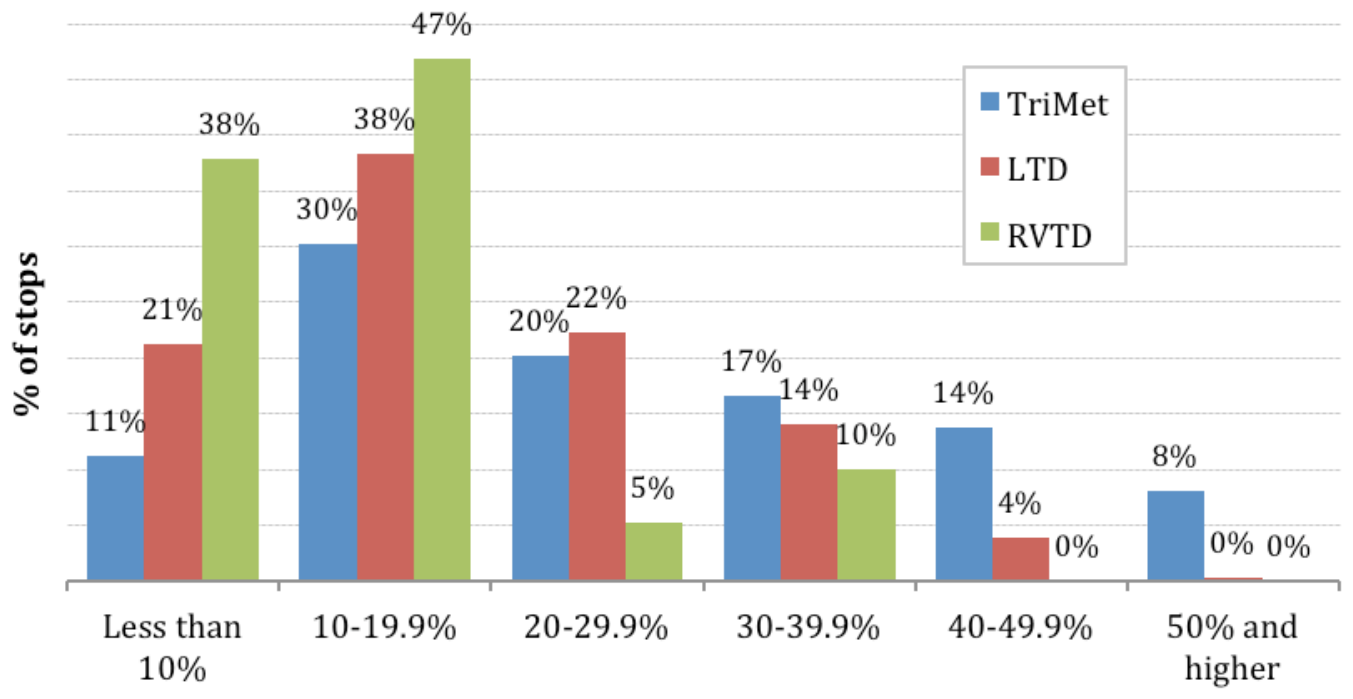

$\%$ of population around stop that has a college degree

Figure 4.9: Distribution of Stops and \% of Population that has a College Degree

The third relationship is unexpected. The model predicts that as the share of households without vehicles increases, ridership at that stop will decrease. A similar relationship was found in the LTD and RVTD models. However, the TriMet and RVTD models also predict that as the share of households below poverty increases, ridership will increase. The unexpected coefficient for vehicle ownership indicates that when the model controls for income (poverty) and other 
demographics, zero vehicle households have a negative effect on ridership. This may indicate that zero-vehicle households that are not in poverty are not riding transit at a particularly high rate. It may also be due to geography and where zero-vehicle households are concentrated. In the Portland region, most of the stops with high concentrations of zero vehicle households are downtown, inner-Northwest, and Lloyd District areas. In the LTD area, the stops with concentrations of zero-vehicle households were in or near downtown and the University of Oregon campus. It may be that these residents are walking or bicycling to many destinations, rather than using transit.

The final two demographic variables included in the models were the shares of the population under 17 and 65 and older. For both the TriMet and LTD models the share of population under 17 had a positive relationship with ridership. This is expected because most children in this age group cannot legally drive a car. Moreover, at the time in Portland and Eugene, students were eligible for free transit passes; the public transit buses were often used in place of school bus service, particularly at the high school level. . In RVTD, children up to nine years old can ride for free, while those 10-17 are eligible for reduced fares.

The most interesting demographic variable is the share of population 65 years or older, which had a non-significant relationship with ridership in TriMet model, a negative relationship in LTD model, and a positive relationship in RVTD model. As shown in Figure 4.10, Rogue Valley has a higher portion of its stops with a relatively high share of the population over 65. About onequarter of the RVTD stops have a surrounding population that is at least $20 \%$ older adults. This fits Rogue Valley's reputation as an attractive retirement community. In contrast, only about five percent of TriMet's stops have that high of a share. With more stops having a concentration of older adults in Rogue Valley and Lane County, there is a greater possibility that ridership at those stops can influence the model coefficients, either positively or negatively. The direction of the relationship might be due to unique characteristics of older adult communities in the two areas. For example, it may be that there are some older adult communities in Rogue Valley that are particularly well-served by transit and do not provide their own competing transportation services. 


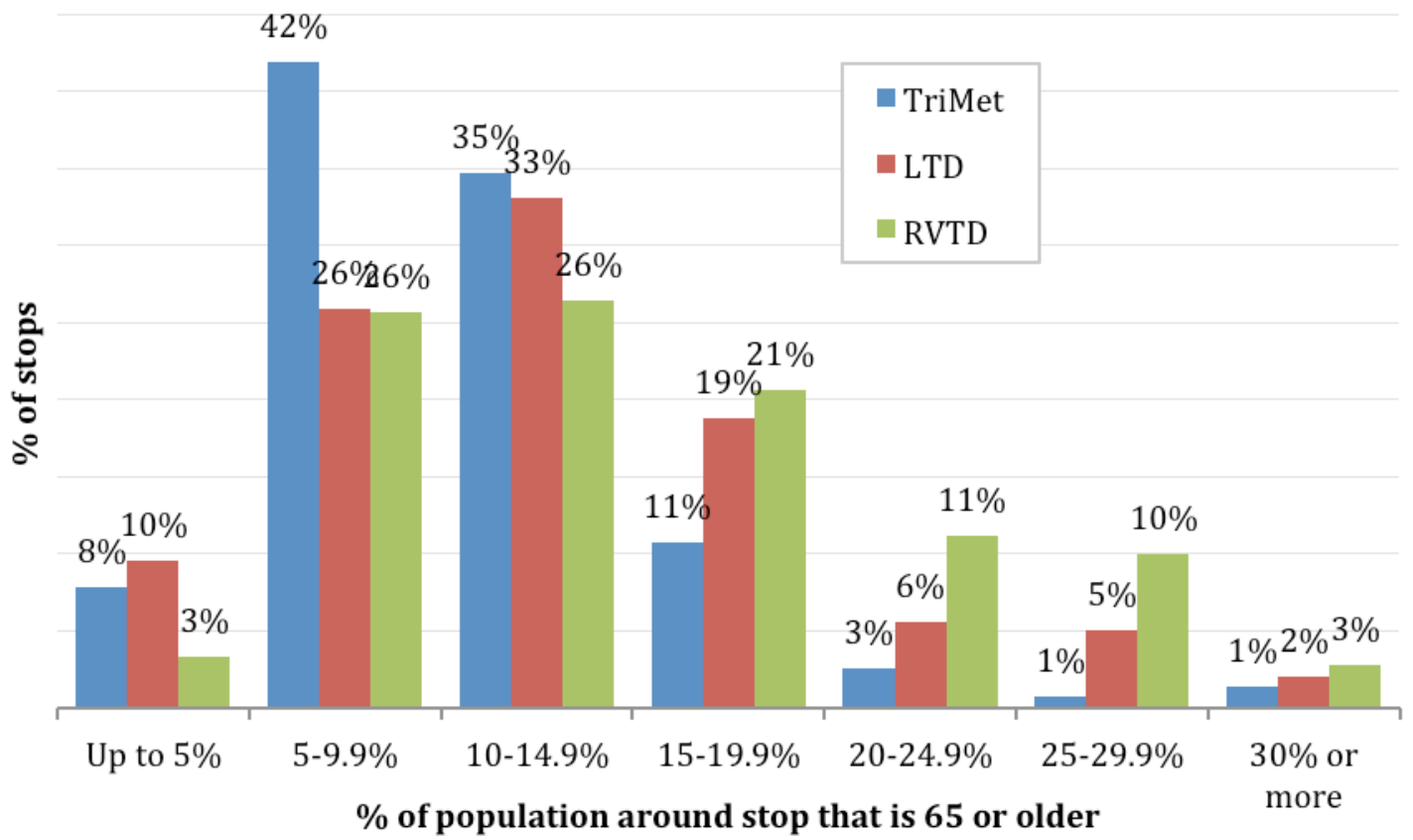

Figure 4.10: Distribution of Stops and \% of Population that is 65 or older

\subsubsection{Transit Service Variables}

The transit service variables explain about $41 \%$ of the variance in the TriMet model, $46 \%$ in the LTD model, and 27\% in the RVTD model. All of the variables were significant in TriMet and LTD models, with coefficients in the expected direction. In the RVTD model, two variables, transfer stop and transit coverage time, were not significant even though their coefficients have the expected sign. This is not surprising when considering the relatively small sample size of the RVTD model (350) compared with LTD (1400) and TriMet (7214). There was less variation within the variables in the RVTD service area. For example, there are only 11 transfer stops, and all the stops have a coverage time ranging from 10.5 to 13.5 hours.

In general, transit ridership was higher at transfer stops, transit centers and stops with park and ride lots, however it was lower as the number of nearby stops increased. This makes sense, as a greater number of stops nearby (for the same route or other routes) can disperse riders. Longer headways decreased ridership, and longer coverage time increased ridership. The magnitude of the variables was similar among the three models, with a few exceptions. Transfer stops had a greater effect on ridership in the Portland region; all else being equal, ridership at a transfer stop was over $58 \%$ higher than at other stops. This likely reflects the larger transit network, providing more opportunities to transfer. Longer headways appear to have a slightly larger effect on RVTD and TriMet ridership than LTD ridership. Each extra minute of headway is associated with a four to five percent drop in ridership for RVTD and TriMet, compared to a two percent drop for LTD. The larger effect for RVTD might be explained by the limited range of values: 30, 45, and 60 minutes (based upon schedules). Riders may be even more sensitive to waiting times in this range. For TriMet, where the headways ranged from 11 to 76 minutes (based upon on-board data), riders overall might be more time sensitive, indicating that they are more likely to be 
“choice” riders. Proximity to a park and ride lot had a significant and positive association with ridership, and this is consistent among the three models. Finally, ridership at rail and BRT stations is about three times and two times higher, respectively, than ridership at bus stops.

\subsubsection{Transportation Infrastructure Variables}

The three transportation infrastructure variables explain about one-percent of the variation in each model. Street connectivity is positively associated with ridership in both the TriMet and LTD models, indicating that the short walking distances afforded by increased connectivity likely improves accessibility. Street connectivity is not significant in the RVTD model, though the coefficient is positive. This may be due to the smaller range in levels of street connectivity among the stops in the RVTD area compared with LTD and TriMet. While a small overall percentage, this result confirms earlier work by Ryan and Frank (2009), which showed the significance of the pedestrian environment in increasing transit use (in San Diego), although their work accounted for only 0.5 percent of the variation.

The presence of multi-use pedestrian and bicycle paths was associated with increased transit ridership in Portland, while the presence of nearby bike lanes was associated with increased transit ridership in both Portland and Rogue Valley. This may be capturing both direct and indirect relationships. All TriMet buses are equipped with bike racks, allowing for easy transfer between the modes. Therefore, the two types of infrastructure (bike facilities and transit) may be synergistic. On the other hand, bike lanes or paths may be located along corridors that exhibit some other characteristic that is associated with transit ridership - a variable that we have not otherwise accounted for in our models.

\subsubsection{Land Use Variables}

The land use variables explain about $4-5 \%$ of the variance in the TriMet and LTD models, while $17 \%$ in the RVTD model. The reasons for this large difference are not immediately apparent and are worth further exploration.

The significant effects of the individual variables are generally consistent with theory, though the models are not consistent with respect to which variables are significant. As expected, the better the job accessibility of the stop, the higher the ridership; this is found in all three models. As the total employment around a stop increases, so does ridership - but only in the Portland region. There is no significant relationship in Lane County and Rogue Valley. In both Portland and Rogue Valley, as the total population near a stop increases, so does ridership. This variable is not significant for Lane County; moreover the coefficient is negative.

The portion of land used for multi-family residential (MFR) is significantly and positively associated with higher ridership in all three locations. Commercial land use is also positively associated with ridership in all three areas, but only significant in Portland and Rogue Valley. The effect of MFR is somewhat higher in Lane County, while the effect of commercial land uses is larger in Portland and Rogue Valley. The proportion of acreage in single-family housing is not significantly related to ridership in any of the models. It is included because it does help control for other relationships. 
The proximity to possible pedestrian-oriented destinations is consistently significant in all three models; for each additional destination within the $1 / 4$-mile buffer, ridership goes up by $1-2 \%$. The significance of this variable likely explains why the land use mix entropy index is not significant in the TriMet and RVTD models. This indicates that the pedestrian destination measure may have more power for predicting transit ridership. However, land use mix remains significant in the LTD model even after controlling for proximity of pedestrian-destinations.

Stops located in downtown Portland have higher ridership, even after accounting for density, other land use factors, and transit service characteristics. This indicates that there is something else, not explicitly captured in our model, about downtown Portland that attracts transit riders. On the other hand, there was no significant relationship between ridership and a stop being located near the University of Oregon and Southern Oregon University campuses, which might be expected to be major transit destinations. Distance to downtown is negatively associated with ridership in Portland, indicating that ridership goes down at stops farther away from the city center. However, the opposite relationship was found in Lane County and Rogue Valley ridership increases further from downtown. Finally, the presence of parks is associated with lower transit ridership. This makes sense, in that parks are not a common transit destination.

\subsubsection{Land Use and Service Frequency}

We used the TriMet model to predict how changes in several land use variables would affect ridership, given three different levels of service: 15-minute, 30-minute, and 60-minute headways. This is done by holding all other variables in the model constant. The results reveal that for some of the land use variables, the positive effects are most pronounced when service is best - at the 15-minute headways. For example, Figure 4.11 shows the effect of pedestrian destinations on ridership. The slope for 15-minute headway line is steepest, indicating that adding the same number of pedestrian destinations around a stop with 15-minute service would have a greater effect on ridership than adding them to a stop with 60-minute service. There is a similar relationship for street connectivity (Figure 4.12) and population density (Figure 4.13), but not employment density (Figure 4.14). 


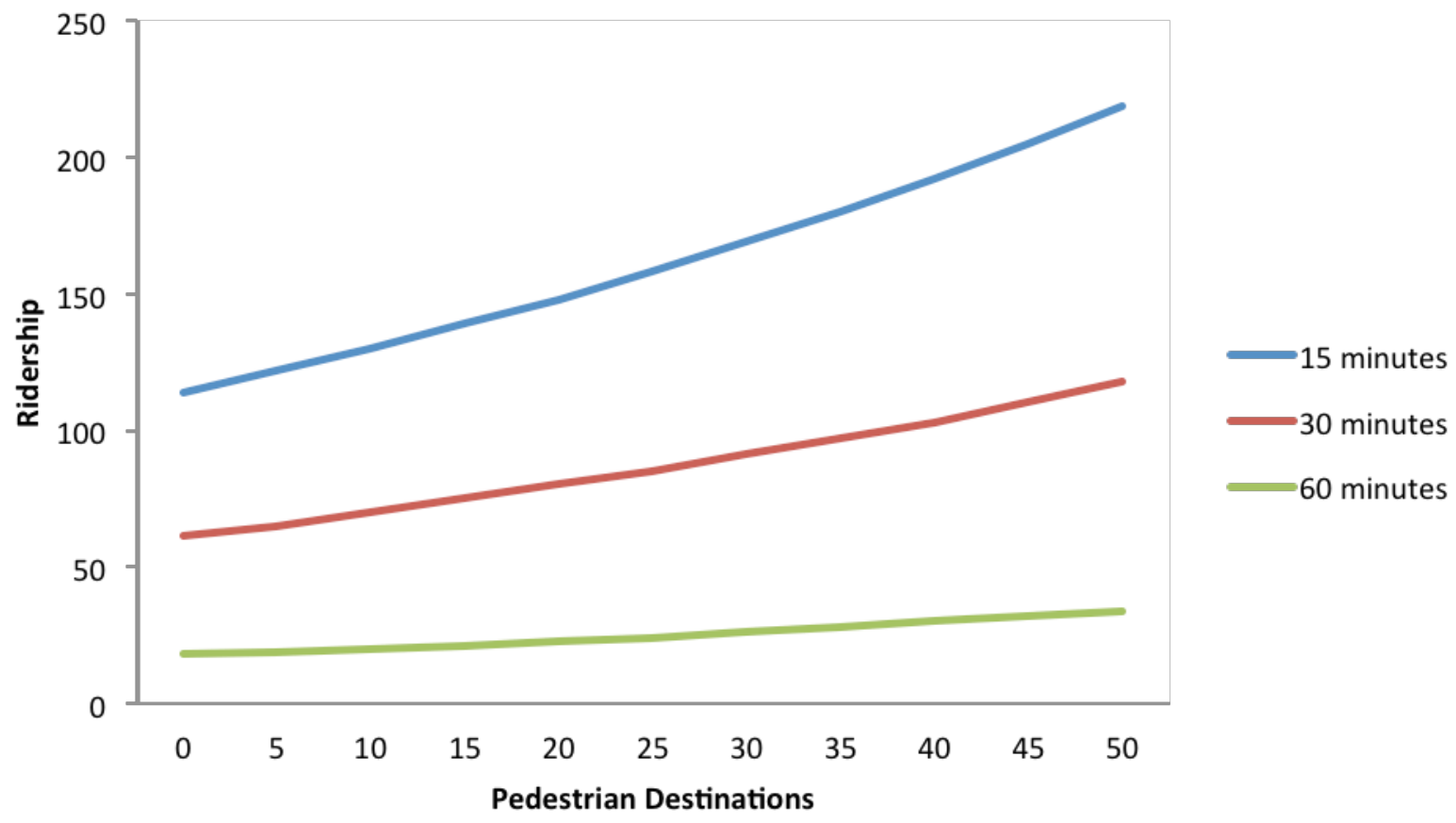

Figure 4.11: Effect of Pedestrian Destinations on Ridership, Controlling for Service Frequency

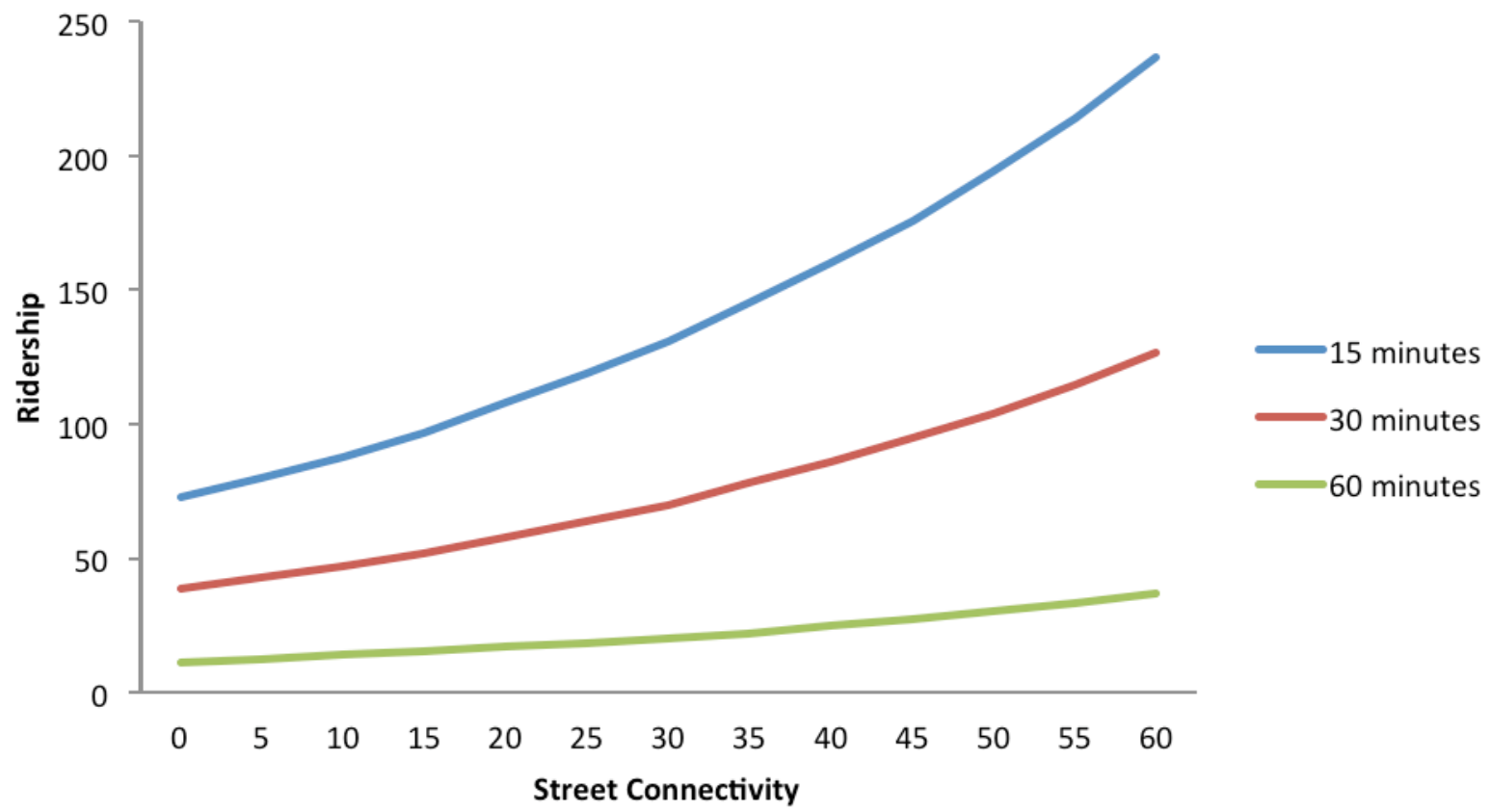

Figure 4.12: Effect of Street Connectivity on Ridership, Controlling for Service Frequency 


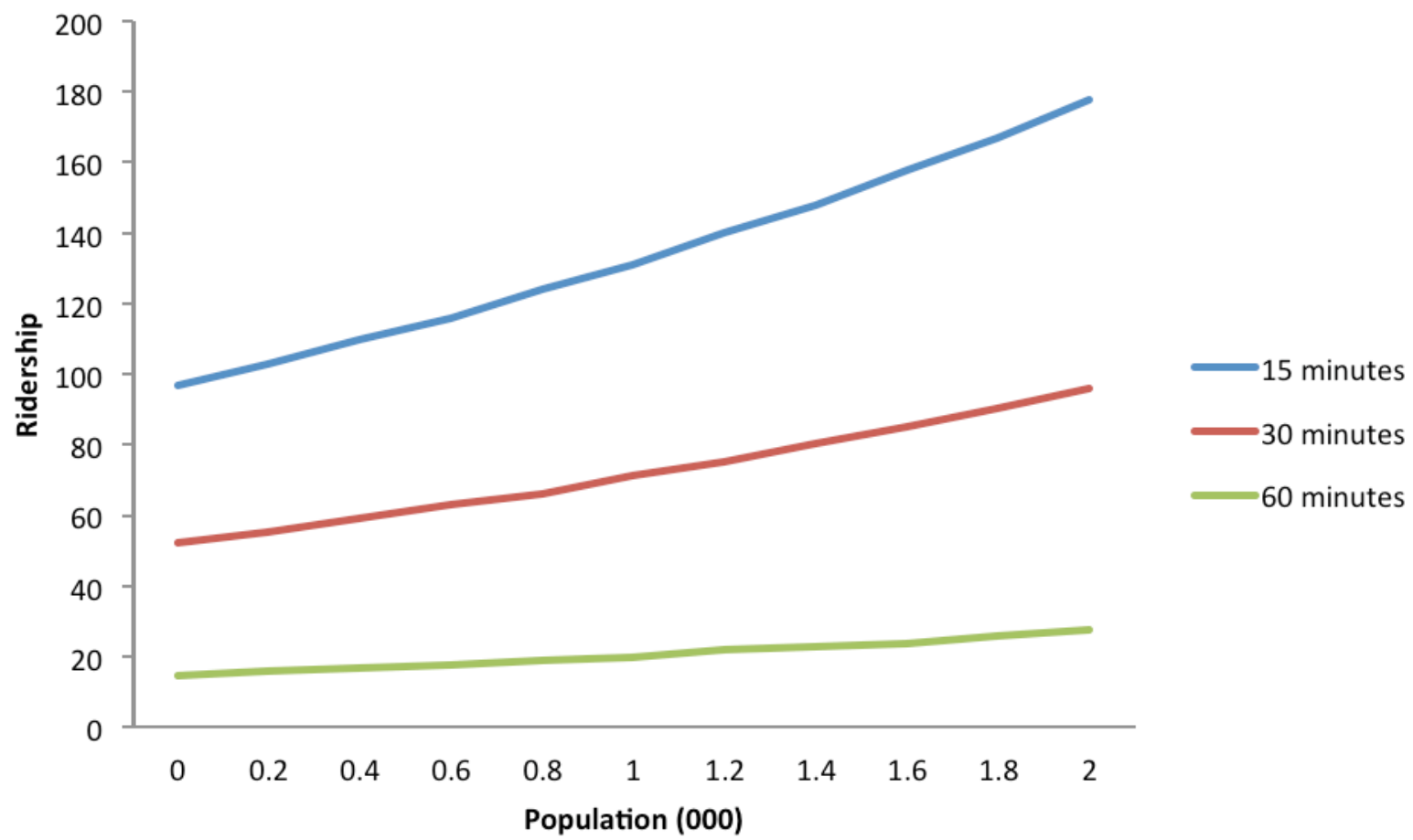

Figure 4.13: Effect of Population Density on Ridership, Controlling for Service Frequency

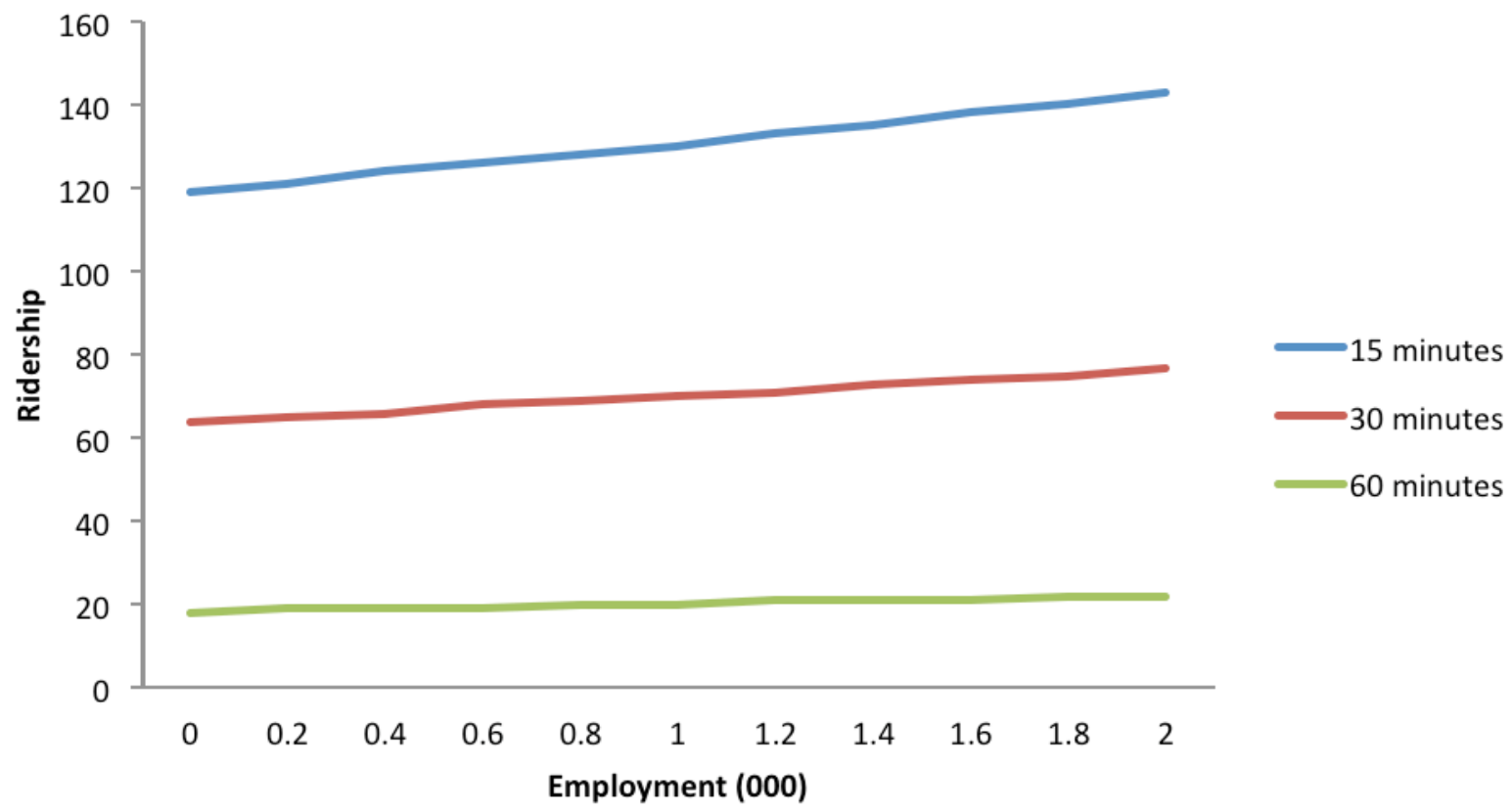

Figure 4.14: Effect of Employment Density on Ridership, Controlling for Service Frequency 


\subsection{SUMMARY AND POTENTIAL APPLICATIONS OF REGRESSION ANALYSIS FINDINGS}

To summarize the regression analysis, there are six primary findings:

1. Transit service characteristics, including frequency are the most significant predictors of ridership;

2. Demographics can have an important effect on ridership, though the patterns are not always consistent;

3. While non-transit transportation infrastructure explains little, street connectivity is a significant component;

4. The number of pedestrian-oriented destinations within $1 / 4$ mile of the transit stop is a significant indicator of transit usage;

5. Density and job accessibility also matter. Higher population density, a larger share of land devoted to multi-family housing, and greater job accessibility contributes to higher ridership. In Portland, land devoted to commercial uses also correlated with higher ridership; and

6. Adding pedestrian destinations, improving street connectivity, and increasing population density around transit stops would have a greater impact on ridership when transit service is best (i.e. 15-minute headways compared to 30- or 60-minute headways).

The findings from the regression models can also be used to test different policy scenarios. One example of this is illustrated in Table 4.6. The ridership estimates are for a non-transfer bus stop with three different frequencies of service: 15, 30, and 60 minutes. This hypothetical analysis assumes 17 hours of service and uses the average demographic characteristics for the TriMet stops. The three scenarios test very low, medium, and very high levels of livability with respect to transit. The ridership estimates use the coefficients from all three models, thus producing a range of potential ridership outcomes. The very low scenario is based upon characteristics found in the lowest five percent of the stops in the TriMet system and could be considered a "worst case" for ridership. The second scenario is based upon median values and might be considered typical in a larger urban area, which the high scenario would typically be found in a higherdensity center or downtown. These examples are for illustrative purposes only, but they do show the value of both improving service frequency in areas with strong livability characteristics and improving the land use characteristics from a typical environment to a more diverse and dense one if the objective is to increase transit ridership. This type of scenario analysis could be run using a spreadsheet and inputting values specific to a stop. 
Table 4.6: Scenario Analysis Using the Regression Models

\begin{tabular}{|c|c|c|c|c|}
\hline & & \multicolumn{3}{|c|}{ Estimated daily ridership } \\
\hline & & $\begin{array}{l}\text { Headway: } \\
15 \text { minutes }\end{array}$ & $\begin{array}{l}\text { Headway: } \\
30 \text { minutes }\end{array}$ & $\begin{array}{l}\text { Headway: } \\
60 \text { minutes }\end{array}$ \\
\hline \multicolumn{5}{|c|}{ Scenario 1: Very Low Level of Transit Livability } \\
\hline \# of 3+-way intersections & $0-5$ & \multirow{6}{*}{$0-50$} & \multirow{6}{*}{$0-35$} & \multirow{6}{*}{$0-15$} \\
\hline Total Employment & $0-20$ & & & \\
\hline Total Population & $0-200$ & & & \\
\hline$\%$ of MFR land use & $0 \%$ & & & \\
\hline$\%$ of COM land use & $0 \%$ & & & \\
\hline Pedestrian Destinations & 0 & & & \\
\hline \multicolumn{5}{|c|}{ Scenario 2: Medium level of Transit Livability } \\
\hline \# of 3+-way intersections & $25-30$ & \multirow{6}{*}{$10-80$} & \multirow{6}{*}{$5-50$} & \multirow{6}{*}{$2-25$} \\
\hline Total Employment & $350-400$ & & & \\
\hline Total Population & $900-1,000$ & & & \\
\hline$\%$ of MFR land use & $3 \%-4 \%$ & & & \\
\hline$\%$ of COM land use & $10 \%-12 \%$ & & & \\
\hline Pedestrian Destinations & $4-6$ & & & \\
\hline \multicolumn{5}{|c|}{ Scenario 3: High level of Transit Livability } \\
\hline \# of 3+-way intersections & $60-65$ & \multirow{6}{*}{$250-1,250$} & \multirow{6}{*}{$140-700$} & \multirow{6}{*}{$40-200$} \\
\hline Total Employment & $3,500-4,000$ & & & \\
\hline Total Population & $1,800-2,000$ & & & \\
\hline$\%$ of MFR land use & $20 \%-25 \%$ & & & \\
\hline$\%$ of COM land use & $40 \%-50 \%$ & & & \\
\hline Pedestrian Destinations & $30-40$ & & & \\
\hline
\end{tabular}




\subsection{URBAN DESIGN FINDINGS}

While the above analysis is unique in that it is based on comprehensive, metropolitan scale transit usage analyzed at the stop level, the urban form and transit stop context is difficult to derive from standard data sets. The analysis calculated a set of variables within one quarter of a mile of each transit stop, but the quality of the urban form within that quarter mile, especially as each land use potentially connects to a transit stop is hard to assess with standard sets of land use or street-based GIS data sets.

Looking at the urban design around transit stops is an important way to understand how individuals may interact within the landscape to see how accessible transit is to the local land use. Some of the subtleties of local places, such as pedestrian paths that may not be in a GIS database or the presence of major barriers that cut off areas of potential transit riders, can only be understood by looking at different urban design aspects.

To understand the potential influence of urban form on ridership, sixty outlier stops in the TriMet and LTD service areas were identified to see whether the design and form of the area within $1 / 4$ mile of the transit stops could help explain why teach transit stop either under or overperformed statistical expectations based on the regression analyses discussed above. There were two primary steps in the analysis:

1. An aerial photo and street map for each transit stop area was printed and visually analyzed for a variety of urban form elements, including:

a. Connectivity: paths, streets, and routes that exist but not appear on official GIS databases because the streets are private, paths are separate from streets, or routes that are "unofficial" such as across a parking lot or empty lot.

b. Barriers: physical or spatial barriers that would prevent a pedestrian from getting to/from the transit stop to the rest of the area within the $1 / 4 \mathrm{mile}$ buffer.

c. Competing stops: looking where other transit stops may be in close proximity to one another and cannibalizing ridership.

d. Density distribution: understanding where density of activity (commercial, industrial, or residential) is happening relative to the transit stop and the remainder of the $1 / 4$ mile buffer area to see if there is a disconnect between density of activity and transit stop location.

2. Sorting of situations into logical groups and identifying the urban design characteristics that likely explain transit ridership not captured in the regression variables. 
There are a number of potential barriers that arose in the urban form analysis that separate transit stops from the surrounding environment, including: freeways and other large roadways, city block structures that limit more direct access, walls that separate disparate land uses and limit pedestrian connectivity, and parking lots that create virtual barriers by creating unpleasant pedestrian environments.

Figure 5.1 illustrates a large continuous block acting as a barrier between a residential neighborhood and the local transit stop. In this situation the long vertical block, without an eastwest access, prevents efficient access between the transit stop and neighborhoods to the east. While it is technically possible to walk between these neighborhoods and the transit stop is within the quarter mile analysis zone, the reality of the journey, as illustrated by the red arrows from one internal neighborhood location to the transit stop, shows that the journey to the transit stop is unnecessarily long. Thus, the connectivity of the neighborhood street network may be positive and the density and overall proximity of housing to transit may be positive, but the large city block creates a barrier that turns what could be a short and direct journey to the transit stop to a longer and more circuitous one. The result is lower transit ridership than what would have been expected given the land use, population density, transit service, and street connectivity variables.

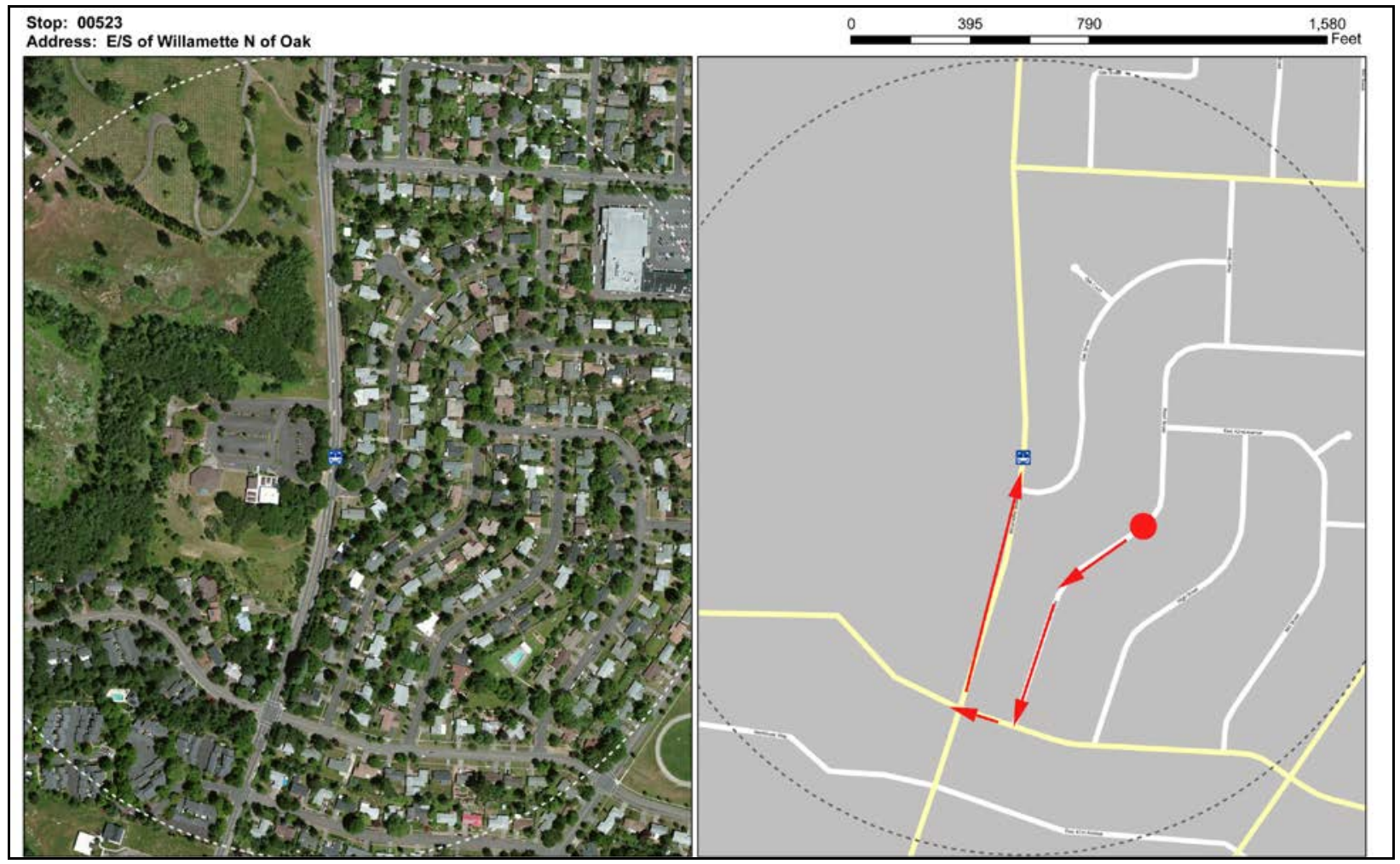

Figure 5.1: Large Block Barrier

Figure 5.2 shows an additional example where long horizontal blocks to the north and the south of a transit stop (red rectangles) prevents access from a majority of the surrounding neighborhood to the transit stop, resulting in less than expected transit utilization. There are very 
few north-south access points, which significantly reduces access to transit from the surrounding neighborhood.

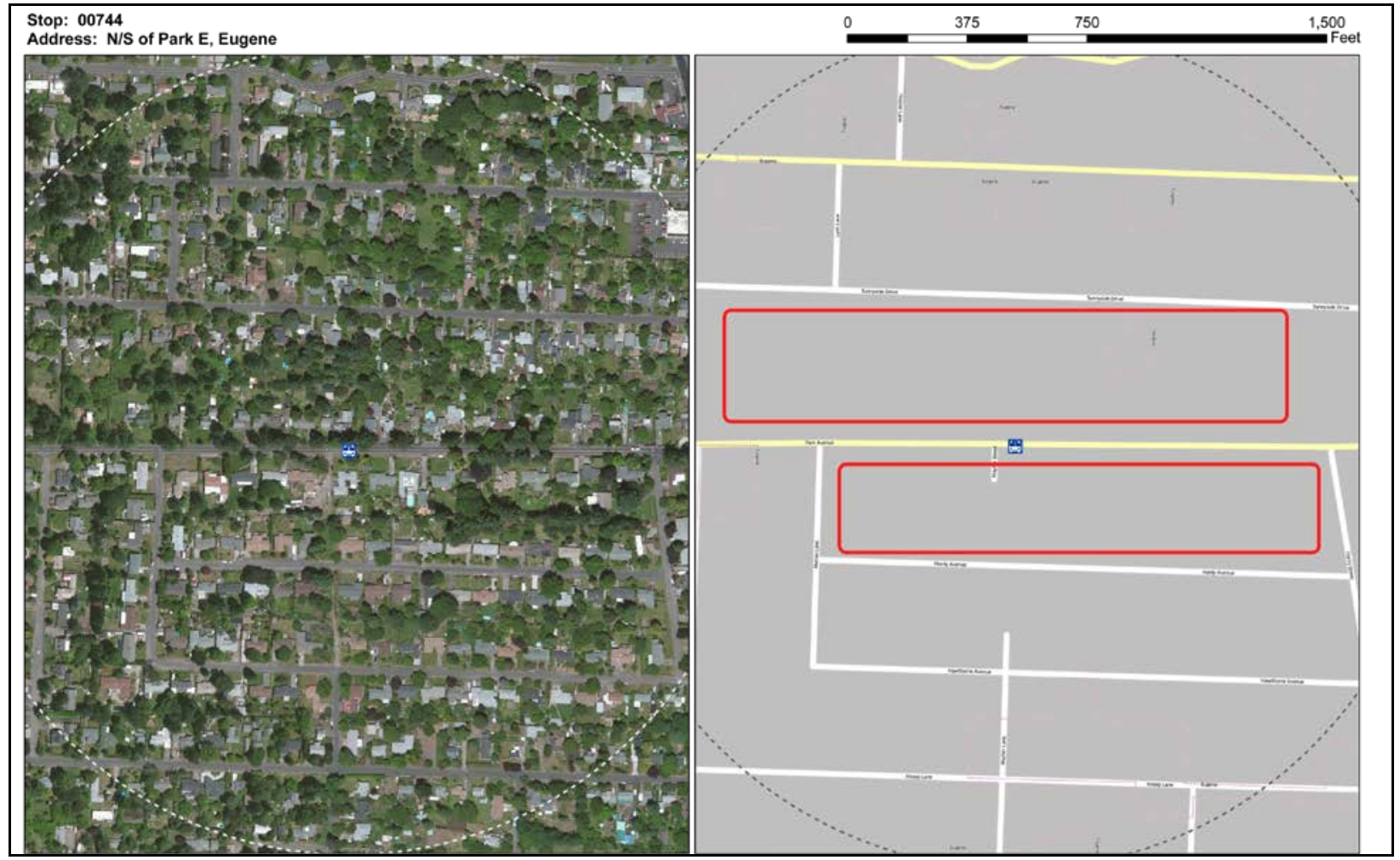

Figure 5.2 Large Block Barrier

Sometimes barriers that prevent pedestrian access are as simple as a single wall that disconnects different land uses. In Figure, there is a wall (shown in red) that separates a higher density multi-family housing area to an adjacent bus stop (and an adjacent shopping center). With no direct access through this separating wall, pedestrians would need to take a circuitous route between transit stop and housing. Moreover, even if there were a path through the wall, the continuity of the shopping center and the expansive parking area both provide barriers to pedestrians; the buildings create an obvious physical barrier and the parking lot creates a perceived barrier as the parking environment is quite uncomfortable for pedestrian mobility. 


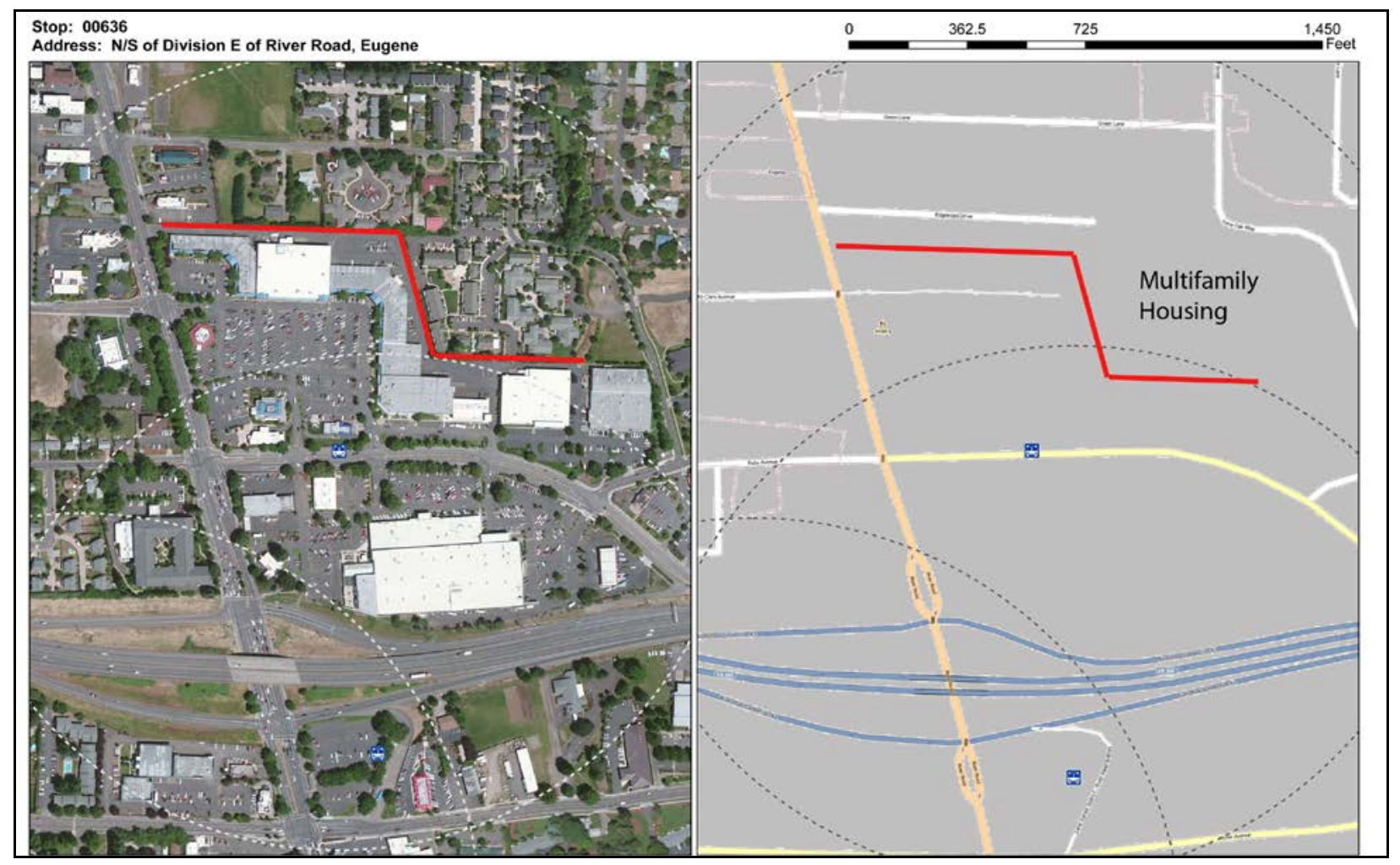

Figure5.3: Barriers between Dissimilar Uses

In some cases, the overall density or mixture of land uses within $1 / 4$ mile of a transit stop meets the general criteria for enhanced transit use, but the actual distribution of those uses or densities over the $1 / 4$ mile distance are such that transit is underutilized. Figure 5.3 also shows the spatial disconnect between the presence of higher density housing and the location of the transit stop. Previously, the barrier between this housing and the transit stop was described in terms of the physical barriers between the two, but the transit environment can also be understood by the physical separation between transit and housing. In fact, the most prevalent use of land near the transit stop is surface parking, which immediately signals a pedestrians unfriendly place.

Greater proximity between transit and the origins or destinations are important elements of the urban form that do not always get captured when considering an entire $1 / 4$ mile catchment area for analysis. Figure 5.4 shows a slightly extreme version of this phenomenon. In this case, there is some mixture of land use and some residential areas (to the north), but neither are in any way close to the transit stop. While clearly there is some re-development occurring within this area, the example highlights the potential problem with simply calculating total destinations or density or land use mix within the broader $1 / 4$ mile area without taking into account the distance of those uses or densities from the actual transit stop. 


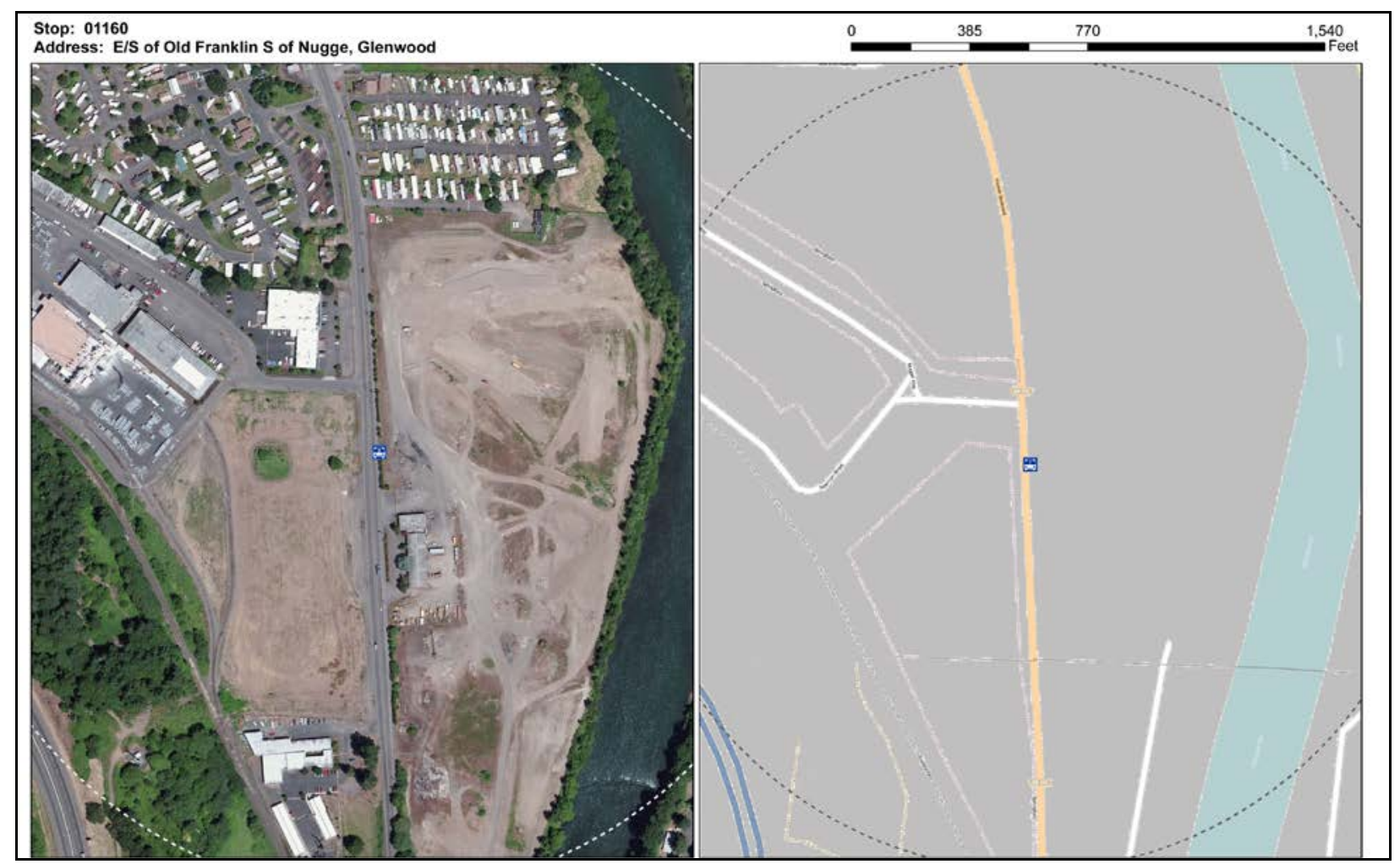

Figure 5.4: Spatial Dispersion of Land Uses

Figure 5.5 shows a transit stop that had less than expected transit ridership based on the surrounding land use mix, street connectivity, and density, and demonstrates three key issues that only appear when investigating urban form. First, about a third of the analysis area is inaccessible to the transit stop simply due to the presence of a railroad track and freight-train adjacent uses. It may be preferable in analyzing an area with this feature by "removing” the inaccessible land and re-calculating the variables only within the area physically accessible from the transit stop. Second, the urban design and land use of the area most adjacent to the transit stop are not pedestrian-supportive. On the east is an electrical power sub-station and on the west are parking lots between transit stop and potential destinations. Denser, multi-family housing is within $1 / 4$ mile of the transit stop (to the west), but beyond these large surface parking areas with no clear pedestrian-friendly access path; thus the location and the connectivity of this denser development with the transit stop is non-existent. 

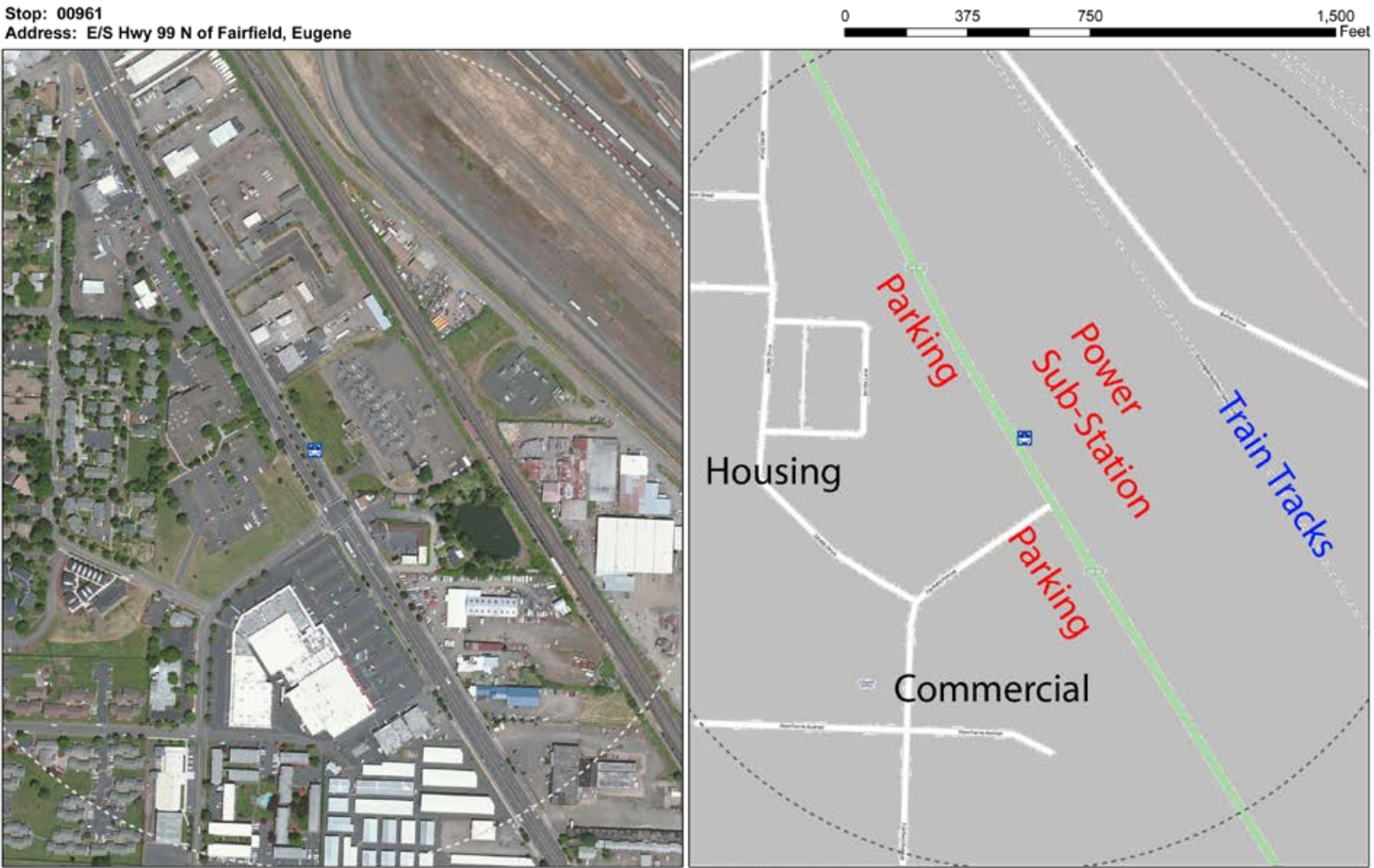

Figure 5.5: Multiple Barriers

One final element of this location, as shown in Figure 5.6, is the importance of the quality of the actual street environment where one accesses transit. In this case, the transit stop is mid-block on a wide road surrounded by very open spaces (parking and non-developed lots). Transit users would feel isolated and unprotected in such an environment as the urban design does nothing to communicate to the transit user / pedestrian that s/he belongs in that space. With such design, it is likely that only captive riders, rather than choice riders, would use transit.

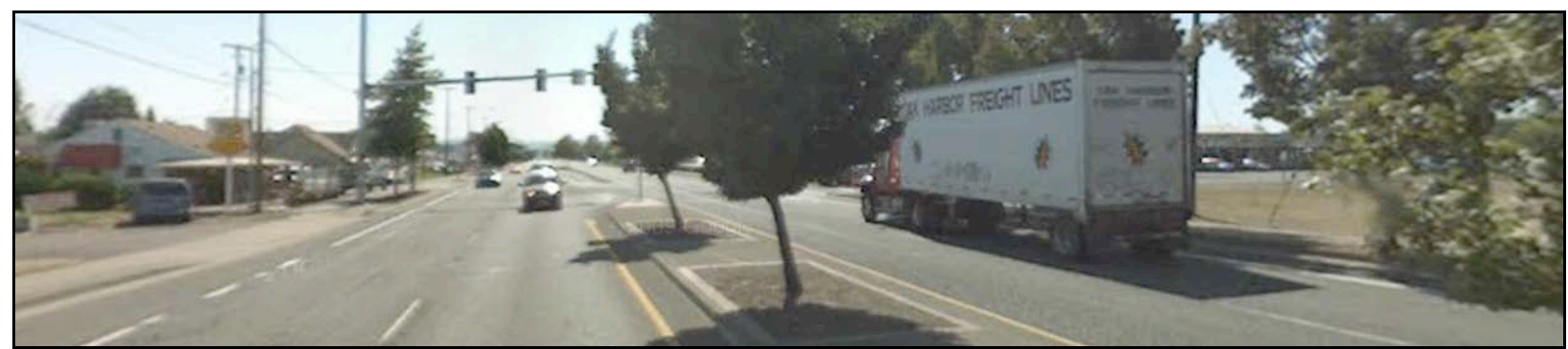

Figure 5.6: Quality of Street Environment 


\subsection{RECOMMENDATIONS}

There are three general categories of recommendations that emerge from this research: 1) policy recommendations related to transit ridership; 2) recommendations for core, universal transit and livability indicators; and 3) methodological and future research recommendations.

\subsection{POLICY RECOMMENDATIONS}

This research project identified three key policy areas where both transit agencies and local or regional governments could bring about a more transit-supportive urban form.

1. Service frequency is clearly important. Frequency of service is a very important predictor of transit use. Reducing waiting time and eliminating anxiety about when the next transit vehicle will arrive are important factors in choosing transit, and more frequent service addresses both issues. Holding all else equal in terms of urban form, transit ridership increases when transit service increases. This finding is not new. What this research does point out is that if resources do exist to improve transit frequency (or avoid service cuts), priority should be given to areas with more supportive land use and urban form.

2. Clustering of density and destinations at transit stops important. Transit service needs to operate within a supportive land use pattern with destinations within short walking distances of transit stops. Thus, clustering such destinations, in terms of mixes of land uses as well as increased population and employment density close to transit is important. The models developed from this research can be used to prioritize locations for changing land use and for developing land use targets (e.g. a minimum density or number of destinations) based upon desired transit ridership.

3. Connectivity is important as measured both by GIS analysis of existing networks and urban form analysis of connectivity barriers. While clustering destinations close to transit stops is important, if there is no comfortable way to get to/from transit from the adjacent areas, then such clustering will have limited impact. Transit users are often pedestrians before and/or after their trip, thus creating safe, convenient, and direct ways to walk to the transit stop is critical. There are three scales of importance: 1) the area immediately adjacent must be pedestrian-friendly, including the ability to cross the street; 2) street connectivity within one-quarter of a mile can indicate pedestrian accessibility; and 3) other barriers (i.e. large parking lots without clear pedestrian access, walls separating residential areas from adjacent commercial areas, or transit stops on large arterials without clear crossings) to connectivity need to be minimized for pedestrians. Most of the connectivity work must happen at the municipal level (but can be required for new developments or redevelopment projects), where decisions about connectivity and pedestrian facilities are made. 


\subsection{LIVABILITY INDICATOR RECOMMENDATIONS}

A key component of this research is to identify transit livability indicators that transit agencies and communities in Oregon can use to assess and evaluate their performance. There are three key transit livability indicators that capture the quality of transit service, the ability to get to transit stops on foot, and the presence of destinations to reach from each transit stop. These three key indicators utilize existing data that can be put into practice relatively easily by transit agencies and local planners:

1. Transit Quality: The first and most important indicator is one of transit quality. Service frequency is a very important measure of quality and can be calculated by the number of busses passing a specific transit stop divided by the hours of operation. One variation that can be applied to this calculation is to separate hours of service into peak and nonpeak periods of operation in order to differentiate different types of transit use and users throughout the day. For most transit lines, the total hours of operation can be determined by calculating the time between the first and last bus of the day; in some systems and on some transit lines, however, hours of operation should also take into account periods of no service during non-peak times. In such cases, we recommend reducing the "hours of operations" calculation for any transit stop with transit service less frequent than one vehicle per hour.

2. Built Environment: Transit users are overwhelmingly pedestrians before and/or after using transit, thus measuring some aspect of the walkable infrastructure around transit stops is important. In this regard, we recommend using street intersection density as a good proxy for determining a basic level of walkability. Of course, there are many variables that influence walking that are different from street connectivity (i.e. presence of sidewalk, separation from traffic, perception of safety, safe ways to cross intersections, etc.), but measures of street connectivity do provide a basic characterization of urban form related to walking (Southworth 2005) and can be easily calculated with existing data and standard GIS procedures.

3. Destinations: The third important element of transit livability, especially for non-work trips, is measuring pedestrian-oriented destinations within one-quarter mile of each transit stop. In this study, we have a very detailed tax lot-based database to measure the number of pedestrian-oriented destinations near a stop. These data may not be available in all cases. Recognizing this, we also tested using retail employment data available nationally through the Longitudinal Employer-Household Dynamics (LEHD) data from the Census Bureau as a substitute and found them to be roughly equally useful. Given the ease of data access of LEHD, we recommend using the "retail" category as an indicator of destinations in close proximity to transit stops. 


\subsection{RESEARCH AND DATA METHODS RECOMMENDATIONS}

The following are other research and data-oriented recommendations for future projects:

1. Retail Category of LEHD data a good substitute for Quarterly Employment Data as source for pedestrian destinations. The LEHD retail establishment category provided a good proxy for pedestrian destinations in our model and we recommend its use for future studies. LEHD data is regularly collected by the United States Census Bureau and is freely distributed for all areas of the country using standard census geography. LEHD uses "modern statistical and computing techniques to combine federal and state administrative data on employers and employees with core Census Bureau censuses and surveys while protecting the confidentiality of people and firms that provide the data” (http://lehd.ces.census.gov/led/about-us/FAQ.html).

2. Transit agencies need to standardize stop-level data collection and reporting. Every transit agency collects and compiles stop-level ridership data in its own way, making it difficult to analyze any individual agency's livability performance, let alone comparing across agencies to learn from best practice. To enable more research and comparisons between regions, transit agencies could adopt consistent practices for data collection and reporting that includes boardings and alightings by transit stop over consistent time periods. As more agencies adopt automated passenger counting equipment, this should become easier.

3. Focus on urban design. The design of the pedestrian network surrounding transit stops especially those that are in close proximity to higher densities of commercial establishments and housing - is extremely important. While street connectivity provides a good foundation for the basic potential pedestrian infrastructure, in reality, streets are often a poor proxy for pedestrian mobility. We recommend that transit agencies, in partnership with their local municipalities, focus on enhancing the pedestrian infrastructure design in the following ways:

1. Use aerial images to evaluate the basic block structure, transit location, and adjacent connections. Studying the relationship of the transit stop to housing, commercial centers, and employment locations can provide insight into how well positioned transit stops are relative to the streets that people will use to get to and from the stop. Stops located in the middle of a long residential block, for example, can add significant walking distance to the transit journey and reduce the number of households or destinations accessible by transit.

2. Audit existing formal transportation infrastructure, including streets, sidewalks, intersections, and off-street paths adjacent to transit stops for their pedestrian friendliness. Simply looking at street connectivity does not tell how a pedestrian experiences the local environment. Some basic features such as the presence of sidewalks and the separation from traffic can significantly impact the perception of safety and incorporating such assessments can be insightful as to how transit stops connect to the local environment. There are a variety of existing tools or indicators to help in that process, many of which may be possible to gather with tools such as Google Streetview. 
3. Audit the informal pedestrian networks surrounding transit stops that often indicate pedestrian use despite barriers that make walking harder. For example, near many suburban transit stops adjacent to commercial strip malls, there are walls separating the commercial areas from the high-density multi-family housing just adjacent to the commercial area. These walls almost always significantly increase the distance for someone to walk between home and transit stop. In other instances, there may be "goat paths" across fields or even private property resulting from the public trying to walk where no public facilities exist. These are common barriers that restrict potential transit users that site audits can help identify and lead to appropriate retrofits. Such site audits should include the following:

- Walking the area itself, including across parking lots and behind commercial buildings;

- Identifying "goat paths" or other evidence (i.e. propped open fences) of pedestrians creating direct access where no formal route exists;

- Mark these instances on a map or aerial photo; and

- Work with local city planners, commercial owners, and developers to create better pedestrian access that reduces distance to transit stops by increasing the directness of pedestrian paths.

4. Calculate catchment areas based on nearest transit stop. One refinement to our transit stop catchment areas would be to incorporate the locations of nearby transit stops into the creation of catchment areas. For this study, we calculated variables within a one-quarter mile of each transit stop regardless of where nearby stops and their catchment areas may be. We suggest overlapping catchment areas of adjacent stops by an $1 / 8$ of a mile to reflect that people roughly half way in between two stops could equally choose either stop, but otherwise individuals will choose their closest transit location. The result of this refined approach will be that some catchment areas are slightly smaller than what we used in this study, and thus capture fewer destinations, people, and urban form attributes. We do not expect significant changes in the underlying insights from this research, but this refined method would better represent likely behavior of transit users. 


\subsection{REFERENCES}

Agrawal, A. W., M. Schlossberg, and K. Ivin. How Far, by Which Route and Why? A Spatial Analysis of Pedestrian Preference. Journal of Urban Design, Vol. 13, Issue 1, 2008, pp. 81-98.

Banerjee, T., D. Myers, and C. Irazabal. Increasing Bus Transit Ridership: Dynamics of Density, Land Use, and Population Growth (No. 03-24). METRANS, I-3, University of Southern California, Los Angeles, CA. 2004.

Barnum, D. T., S. Tandon, and S. McNeil. Comparing the Performance of Bus Routes after Adjusting for the Environment Using Data Envelopment Analysis. Journal of Transportation Engineering, Vol. 134, Issue 2, 2008, p. 77-85.

Benn, H. P. Bus Route Evaluation Standards. National Academy Press: Available from Transportation Research Board, National Research Council, Washington, D.C., 1995.

Cervero, R. Transit-Based Housing in California: Evidence on Ridership Impacts. Transport Policy, Vol. 1, No. 3, 1994, pp. 174-183.

Cervero, R. Mixed Land-Uses and Commuting: Evidence from the American Housing Survey. Transportation Research Part A: Policy and Practice, Vol. 30, Issue 5, 1996, pp. 361-377. doi:10.1016/0965-8564(95)00033-X

Cervero, R. Built Environments and Mode Choice: Toward a Normative Framework. Transportation Research Part D: Transport and Environment, Vol. 7, Issue 4, 2002, pp. 265284. doi:10.1016/S1361-9209(01)00024-4

Cervero, R. Alternative Approaches to Modeling the Travel-Demand Impacts of Smart Growth. Journal of the American Planning Association, Vol.72, Issue 3, 2006, p. 285.

Cervero, R. Transit-Oriented Development's Ridership Bonus: A Product of Self-Selection and Public Policies. Environment and Planning A, Vol. 39, Issue 9, 2007, pp. 2068 - 2085. doi: $\underline{10.1068 / a 38377}$

Chu, X. Ridership Models at the Stop Level. University of South Florida, Tallahassee, FL for Florida Department of Transportation, 2004.

Eboli, L. and G. Mazzulla. A Methodology for Evaluating Transit Service Quality Based on Subjective and Objective Measures from the Passenger's Point of View. Transport Policy, Vol. 18, Issue 1, 2011, pp. 172-181.

Estupiñán, N., and D.A. Rodríguez. The Relationship Between Urban Form and Station Boardings for Bogotá's BRT. Transportation Research Part A: Policy and Practice, Vol. 42, Issue 2, 2008, pp. 296-306. doi:10.1016/j.tra.2007.10.006 
Ewing, R. Measuring Transportation Performance. Transportation Quarterly, Vol. 49, Issue 1, 1995, p. 91.

Ewing, R., M. DeAnna, and Shi-Chiang Li. Land use impacts on trip generation rates. Transportation Research Record: Journal of the Transportation Research Board, No.1518, 1996, pp. 1-6.

Ewing, R. Best Development Practices: A Primer. EPA Smart Growth Network, 1999, pp. 1-29. http://www.epa.gov/dced/pdf/BestDevprimer.pdf.

Fabish, L. and P. Hass. Measuring the Performance of Livability Programs. Transportation Research Board 2011 Annual Meeting. Washington DC, Transportation Research Board, Washington, D.C., 2010.

Federal Highway Administration (FHWA). 2008 Conditions and Performance: Chapter 4 Operational Performance. Federal Highway Administration. 2008.

Foda, M.A. and A.O. Osman. Using GIS for Measuring Transit Stop Accessibility Considering Actual Pedestrian Road Network. Journal of Public Transportation. Vol. 13, Issue 4, 2010, pp. 23-40.

Furth, P.G. Data Analysis for Bus Planning and Monitoring. Transportation Research Board, Washington, D.C., 2000.

Gleason, J.M. and D.T. Barnum. Toward Valid Measures of Public Sector Productivity: Performance Measures in Urban Transit. Management Science, Vol. 28, Issue 4, 1982, pp. 379386.

Hartman, R.J., E.M. Kurtz, and A.B. Winn. The Role of Performance-Based Measures in Allocating Funding for Transit Operations. National Academy Press, Transportation Research Board, National Research Council, Washington, D.C., 1994.

Kimpel, T.J., Dueker, K J., \& A.M. El-Geneidy. Using GIS to Measure the Effect of Overlapping Service Areas on Passenger Boardings at Bus Stops. Urisa, Vol. 19, No.1, 2007, pp. 5-12.

Kittelson, Associates, Urbitran, Inc., LKC Consulting Services, Inc., Morpace International, Inc., and Queensland University of Technology. A Guidebook for Developing a Transit PerformanceMeasurement System. Transportation Research Board, Washington, D.C., 2003.

Kittelson, Associates, KFH Group, Inc. Parsons Brinckerhoff Quade \& Douglas, Inc. (2003). Transit Capacity and Quality of Service Manual. Transportation Research Board, Washington, D.C., 2003.

Levinson, H. S. The New Transit Capacity and Quality of Service Manual 2nd Edition. TR News, Vol. 232, 2004, p. 25. 
Lin, Jen-Jia, and Ting-Yu Shin. (January 01, 2008). Does Transit-Oriented Development Affect Metro Ridership?: Evidence from Taipei, Taiwan. Transportation Research Board Vol. 2063, 2008, pp. 149-158.

Mishra, S., T.F. Welch, and M.K. Jha. Performance indicators for public transit connectivity in multi-modal transportation networks. Transportation Research Part A, Vol. 46, Issue 7, 2012, pp. 1066-1085.

Nakanishi, Y.J. Bus Performance Indicators: On-Time Performance and Service Regularity. Transportation Research Record, Vol_151, 1997.

O'Sullivan, S. Walking Distances to and from Light-Rail Transit Stations. Transportation Research Record., Vol. 1538, 1996, p. 19.

Pratt, R.H. Traveler Response to Transportation System Changes: New Insights from the Revised Handbook. TR News, Vol. 212, 2001, p. 9.

Pulugurtha and Agurla. Assessment of Models to Estimate Bus-Stop Level Transit Ridership using Spatial Modeling Methods. Journal of Public Transportation, Vol. 15, No. 1, 2012, p. 3352.

Ryan, F. Pedestrian Environment and Transit Ridership. Journal of Public Transportation, 2009.

Ryan, S., \& Frank, L. F. (January 01, 2009). Pedestrian Environments and Transit Ridership. Journal of Public Transportation, 12, 1, 39-58.

Ryus, P., J. Ausman, et al. (2000). "Development of Florida's Transit Level-of-Service Indicator." Transportation Research Record. (1731): 123.

Schlossberg, M. From TIGER to Audit Instruments: Measuring Neighborhood Walkability with Street Data Based on Geographic Information Systems. Transportation Research Record Vol. 1982, 2006, p.48.

Schlossberg, M. and N. Brown. Comparing Transit-Oriented Development Sites by Walkability Indicators. Transportation Research Record, Vol. 1887, 2004, pp. 34-42.

Seggerman, K.E., S.J. Hendricks, AICP, and A.C. Joslin. Guidelines and Performance Measures to Incorporate Transit and Other Multimodal Considerations into the FDOT DRI Review Process. Tampa, Fla., National Center for Transit Research, Center for Urban Transportation Research, University of South Florida, 2008.

Seneviratne, P.N. Acceptable Walking Distances in Central Areas. Journal of Transportation Engineering, Vol. 111, Issue 4, 1985, pp. 365-376. doi:10.1061/(ASCE)0733947X(1985)111:4(365)

Sheth, C., K. Triantis, and D. Teodorovic. Performance Evaluation of Bus Routes: A Provider and Passenger Perspective. Transportation Research. Part E, Logistics And Transportation Review, Vol. 43, Issue 4, 2007, pp. 453-478. 
Southworth, M. Designing the Walkable City. Journal of Urban Planning and Development, Vol.131, No. 4, 2005, pp. 246-257.

TriMet. Pedestrian Walking Access to Transit in the Portland Metro Region- Final Draft Technical Memo \#2: Analysis Results. P.T.A. Commitee. Portland, OR, 2010.

UNC-Chapel Hill, Department of City and Regional Planning. Understanding How the Built Environment Around TTA Stops Affects Ridership, 2006.

Zhao F., Lee-Fang Chow, and Min-Tang Li. (April 2005). A Transit Ridership Model Based on Geographically Weighted Regression and Service Quality Variables, Final Report, Prepared for the Florida Department of Transportation, Tallahassee, FL, 2005. 
APPENDIX A:

VARIABLE CALCULATIONS 



\section{VARIABLE CALCULATIONS}

\begin{tabular}{|c|c|c|}
\hline Category & Variable & Calculation \\
\hline \multirow{7}{*}{ Socio-Demographics } & Age & $\begin{array}{l}\text { ACS block group data intersected with the stop buffer area, population } \\
\text { aged less than } 18 \text {, aged } 18-25,25-65 \text {, and } 65 \text { or older in each } \\
\text { intersecting area were calculated based on the proportion of } \\
\text { intersecting area over block group area, aggregated the data based on } \\
\text { location ID by summing population aged less than } 18 \text {, aged } 18-25,25- \\
65 \text {, and } 65 \text { or older within all intersecting area. Ratio of population } \\
\text { aged less than } 18 \text {, aged } 18-25,25-65 \text {, and } 65 \text { or older was calculated } \\
\text { respectively by dividing each age group by total population within } \\
\text { each buffer area. }\end{array}$ \\
\hline & Employment & $\begin{array}{l}\text { Employment data at the tax lot level within each stop buffer area was } \\
\text { aggregated to assign average employment within the stop buffer area. }\end{array}$ \\
\hline & Gender & $\begin{array}{l}\text { ACS block group data intersected with the stop buffer area, female } \\
\text { population in each intersecting area are calculated based on the } \\
\text { proportion of intersecting area over block group area, aggregated the } \\
\text { data based on location ID by summing female population within all } \\
\text { intersecting area. Ratio of female population was calculated by } \\
\text { dividing the female population by total population within each buffer } \\
\text { area. }\end{array}$ \\
\hline & Income & $\begin{array}{l}\text { Average household income within each stop buffer area. ACS block } \\
\text { group data intersected with Stop/Station quarter buffer, income in } \\
\text { each intersecting area are calculated, aggregated the data based on } \\
\text { location ID by calculating the mean of income in each intersecting area. }\end{array}$ \\
\hline & Poverty & $\begin{array}{l}\text { ACS block group data intersected with each stop buffer area. } \\
\text { Households under poverty level in each intersecting area were } \\
\text { calculated based on the proportion of intersecting area over block } \\
\text { group area, aggregated the data based on location ID by summing } \\
\text { households under poverty level within all intersecting area. Ratio of } \\
\text { poverty is calculated by dividing the households under poverty level } \\
\text { by total households within the buffer area. }\end{array}$ \\
\hline & Population & $\begin{array}{l}\text { Total residential population within the stop buffer area accounting for } \\
\text { water, employed areas and using average population for each } \\
\text { commercial building. A dysemetric correction technique was used to } \\
\text { determine what portion of each buffer is inhabited. This took into } \\
\text { account water, zoning, commercial areas and public lands. The } \\
\text { remaining percentage of each buffer that fell within a buffered area } \\
\text { resulted in that percentage of the buffer population being assigned to } \\
\text { the buffered area. The results from each buffer are summed and added } \\
\text { to determine the population }\end{array}$ \\
\hline & Race & $\begin{array}{l}\text { ACS block group data intersected with each stop buffer area. The } \\
\text { White population in each intersecting area were calculated based on } \\
\text { the proportion of intersecting area over block group area, aggregated } \\
\text { the data based on location ID by summing white population within all } \\
\text { intersecting area. Ratio of white was calculated by dividing the white } \\
\text { population by total population within each buffer area. }\end{array}$ \\
\hline Category & Variable & Calculation \\
\hline \multirow{4}{*}{ Land Use } & Pedestrian generators & $\begin{array}{l}\text { Number of pedestrian generating businesses, such as markets, salons, } \\
\text { and banks, as well as other community resources within each stop } \\
\text { buffer area. Pedestrian Magnets were created from geocoded } \\
\text { employment data using the North American Industry Classification } \\
\text { System (NAICS) codes to identify business by type. }\end{array}$ \\
\hline & Commercial Areas & $\begin{array}{l}\text { Ratio of commercial land use within the stop buffer area. Intersecting } \\
\text { the land use layer with buffer layer, area of COM land was calculated } \\
\text { for all intersecting area, aggregating the COM land area based on buffer } \\
\text { ID }\end{array}$ \\
\hline & Land Use Mix & $\begin{array}{l}\text { Land-use dissimilarity as defined by Song and Rodriguez (2005). The } \\
\text { mix of various land uses within each stop buffer area. Entropy is } \\
\text { measured on a scale of } 0-1 \text {. Based on methodology from the Minnesota } \\
\text { Walking Study GIS protocols by Anne Forsynth (2007). Area of each } \\
\text { type of land use are calculated for each stop buffer area, and entropy } \\
\text { for each buffer are calculated by employing the formula: Entropy }\{[(\mathrm{p} \\
\mathcal{( l n} \mathrm{p})]\} /(\ln \mathrm{k}) \text {. }\end{array}$ \\
\hline & Single-Family Housing & $\begin{array}{l}\text { Single-Family-Ratio of single-family house land use within the stop } \\
\text { buffer area. Intersecting the land use layer with buffer layer, area of } \\
\text { SFR land was calculated for all intersecting area, aggregating the SFR }\end{array}$ \\
\hline
\end{tabular}


land area based on Buffer ID.

Multi-family- Ratio of multi-family house land use within the stop

buffer area. Intersecting the land use layer with buffer layer, area of MFR land is calculated for all intersecting areas, aggregating the MFR land area based on buffer ID.

\begin{tabular}{|c|c|c|}
\hline Category & Variable & Calculation \\
\hline \multirow{4}{*}{$\begin{array}{l}\text { Transportation } \\
\text { Facilities }\end{array}$} & Intersection Density & $\begin{array}{l}\text { Count of all intersections within each stop buffer area, with each } \\
\text { intersection containing } 4 \text { or more possible travel directions. }\end{array}$ \\
\hline & $\begin{array}{l}\text { Intersection Density } \\
\text { Ratio }\end{array}$ & $\begin{array}{l}\text { Ratio of all intersections with three or four way intersections and cul- } \\
\text { de-sacs within each stop buffer area. }\end{array}$ \\
\hline & Trails and Paths & $\begin{array}{l}\text { Total feet of multi-use trails and off street paths within each stop } \\
\text { buffer area. Intersecting multi-use trails and off street paths layer, the } \\
\text { total feet of bike lanes is calculated for each stop buffer area. }\end{array}$ \\
\hline & Bike Lanes & $\begin{array}{l}\text { Total feet of bike lanes within each stop buffer area. Intersecting bike } \\
\text { lanes layer, the total feet of bike lanes was calculated for each stop } \\
\text { buffer area. }\end{array}$ \\
\hline Category & Variable & Calculation \\
\hline \multirow{5}{*}{$\begin{array}{l}\text { Transit Level of } \\
\quad \text { Service }\end{array}$} & Service Frequency & Average time between vehicles per hour at each stop or station. \\
\hline & Service Availability & Number of bus stops within each stop buffer area \\
\hline & Transfer Opportunities & Number of route transfers within each stop buffer area \\
\hline & $\begin{array}{l}\text { Access to Light Rail } \\
\text { (TriMet) or Bus Rapid } \\
\text { Transit (Lane) } \\
\end{array}$ & $\begin{array}{l}\text { Count of Light Rail (LRT) or Bus Rapid Transit (BRT) stations within } \\
\text { each stop buffer area. }\end{array}$ \\
\hline & Park and Ride & Count of park and ride locations within each stop buffer area. \\
\hline
\end{tabular}


APPENDIX B:

GIS METHODS 



\section{GIS METHODS}

\section{AGE}

\section{CONCEPT}

Three age characteristics of residents within the buffer area.

\section{CALCULATION}

Ratio of population within stop buffer area classified by three age groups:

18 or younger, $18-25$, and 65 or older.

\section{DISCUSSION}

\section{Data Sources}

- US Census-ACS 2004-2009 5 years estimation, block groups level

\section{Preprocessing}

Extract data for study area from database

\section{Caveats}

Block group level data can have significant margin of errors for some places and indicators because of the small sampling. We need to be cautious when using the data.

\section{GIS METHODS}

- Intersect

- Calculate area for intersecting features

- Aggregate area by buffer ID

\section{GIS STEPS}

1. Add “Census Block Group” and buffer layers into ArcMap

2. Intersect ACS "Census Block Group” layer with buffer layer

3. Add new field on the new intersecting features, name the new field as "area2"

4. Right click the new field and select "Calculate Geometry" to calculate area

5. Calculate the ratio of "area2" over area of buffer to get the ratio of area

6. Calculate the Population with different age groups based on the ratio of area

7. Aggregate Population with different age groups by stop ID 


\section{BIKE LANE}

\section{CONCEPT}

The basic idea of this is to measure the level of bicycling facilities (bike lanes) around each transit stop.

\section{CALCULATION}

The calculation is the sum of all bike lanes within the stop buffer area.

\section{DISCUSSION}

\section{Data Sources}

- Jackson County-Bike Routes

- LCOG- Bike Routes

- Metro- Bike Routes

\section{Preprocessing}

The bike lanes layers contain attributes for bike lanes as well as low traffic, high traffic, planned, and existing. To obtain only the bikes lanes from the layer, a select by attributes is performed to select "Bike Lane" from the "Bike Mode" field and “Existing” from the "Status" field.

\section{Caveats}

Bike lanes do not indicate other bicycle friendly facilities, such as bike boulevards, low traffic through streets, streets with wide shoulders, and off street connectors.

\section{GIS METHODS}

- Select by Attributes

- Intersect

- Dissolve

- Summary Statistics

- Table Join

\section{GIS STEPS}

\section{TriMet}

1. Load "Bike Routes" and "Stop Buffer" layers into ArcMap

2. Using Select by attributes, select "Bike Lanes" from "Type” attribute field

3. Using Select by attributes, select "Existing" from "Status" attribute field

4. Export selected as "Bike Lanes"

5. Using the Intersect tool, intersect Bike Lanes layer with stops buffer

6. Dissolve Intersected Layer by Stop ID

7. Generate SUM statistics on shapelegnth 


\section{LTD}

1. Load "Bike Routes" and "Stop Buffer" layers into ArcMap

2. Intersect Bike Lanes layer with stops buffer

3. Dissolve Intersected Layer by Stop ID

4. Generate SUM statistics on shapelegnth

\section{RVTD}

1. Load "Bike Routes" and "Stop Buffer" layers into ArcMap

2. Select by Attributes where "Lane Type" = "Bike Lane"

3. Export as "Bike Lane Only"

4. Select by Attributes where "Stage" = "Existing"

5. Export as "Bike Lane Existing"

6. Intersect "Bike Lane Existing” layer with stops buffer, call "Intersected Lanes"

7. Dissolve “Intersected Lanes” by Stop ID

8. Generate SUM statistics on shapelegnth

9. Save as "Bike Lane Stats"

10. Sum Length Field now indicates total feet of facility for each stop ID 


\section{BUS STOP DENSITY}

\section{CONCEPT}

We defined Bus Stop Density as the number of bus stops available within the walkable buffer area around each bus stop. The concept of this measurement is to model transfer opportunities available and spatial concentration of bus stops.

\section{CALCULATION}

Bus Route Density is calculated as the sum of all transit lines within the stop buffer area.

\section{DISCUSSION}

\section{Data Sources}

- LTD- Bus Stops

- TriMet- Bus Stops

- RVTD- Bus Stops

\section{Preprocessing}

The TriMet layers for bus stops and stops also contain Light Rail, Street Car, and Tram. To generate a bus stops only layer, a select by attributes is performed to select "Bus" from the "Type" field and exported as a bus routes and stops respectively. As LTD and RVTD only run busses, the layers required no preprocessing.

\section{GIS METHODS}

- Select by Attributes-Export

- Spatial Join

- Join by Attributes

\section{GIS STEPS}

\section{TriMet}

1. Load "Bus Stops" and "Stop Buffer" layers into ArcMap

2. Select by Attributes-MAX, Tram, Street Car, Trolley from "Type"

3. Delete Selected Records to obtain "Bus Stops Only"

4. Spatially Join "Bus Stops Only" to Stop Buffer Area

5. Select generate Sum Statistics to obtain count field in joined layer

6. Output will be Stop Buffer Area with a count field of bus stops

\section{LTD}

1. Load "Bus Stops" and "Stop Buffer" layers into ArcMap

2. Spatially Join "Bus Stops" to "Stop Buffer"

3. Select generate Sum Statistics to obtain count field in joined layer 
4. Output will be Stop Buffer Area with a count field of bus stops

RVTD

1. Load "Bus Stops" and "Stop Buffer" layers into ArcMap

2. Spatially Join "Bus Stops" to "Stop Buffer"

3. Select generate Sum Statistics to obtain count field in joined layer

4. Output will be Stop Buffer Area with a count field of bus stops 


\section{BUSINESS}

\section{CONCEPT}

The concept is to categorize the land use around the stop by counting the number of businesses in the stop buffer area.

\section{CALCULATION}

Sum the total employment establishments within each buffer area.

\section{DISCUSSION}

\section{Data Sources}

- LCOG-2008 employment data

- Metro-2008 employment data

- Oregon Employment Department-2008 employment data

\section{GIS METHODS}

$$
\text { - Spatial join }
$$

\section{GIS STEPS}

1. Load "Employment" and "Stop Buffer" layers into ArcMap

2. Add a field called "count" for the "Employment" layer

3. Spatial join "Employment" layer with "Stop Buffer" layer, and choose count as statistical method for the field "count"

4. The buffer layer will contain a new field "count" which have numbers of business establishments for each buffer 


\section{COMMERCIAL}

\section{Concept}

This measurement is intended to identify the type of land use around each stop.

\section{Calculation}

Ratio of commercial land use within each stop buffer area.

\section{Discussion}

\section{Data Sources}

- Jackson County-Taxlots

- LCOG-Taxlots

- Metro-Taxlots

\section{Preprocessing}

Category for land use in taxlot data for Lane County is not consistent with the taxlot for Metro. Re-classify the land use data for Lane County is done before calculating the variable.

\section{GIS Methods}

- Select by Attributes

- Intersect

- Calculate area for intersecting features

- Aggregate area by buffer ID

\section{GIS Steps}

1. Load "TaxLots" and "Stop Buffer" layers into ArcMap

2. Select "Commercial" land use from "TaxLots" layer and export as "Commercial"

3. Intersect "Commercial” layer with "Stop Buffer" layer

4. Add new field on the new intersecting features, name the new field as "area2", right click the new field and select "calculate Geometry", calculate area

5. Aggregate "area2" by buffer ID

6. Calculate the ratio commercial land use by dividing of "area2" over area of buffer 


\section{EMPLOYMENT}

\section{CONCEPT}

The idea behind this measure is to capture the total employment within the stop buffer area. Places of employment are meant to capture work related trips.

\section{CALCULATION}

Employment data on the buffer layer is used to assign average employment within the stop buffer area.

\section{DISCUSSION}

\section{Data Sources}

ES-202 - Place based employment records

- LCOG- Lane County Employment

- METRO- Metro Employment

- Oregon Employment Department- Jackson County Employment

\section{Caveats}

The original data collected by the State of Oregon Employment Department tracks employment data geocoded to each tax lot. There is a potential for employment numbers for larger corporate chains with multiple outlets to be aggregated to the tax lot of the corporate office, misrepresenting the spatial distribution of employment. Counties using the data received from the state disaggregate the employment records to individual store locations, however small errors in the data set may be present.

The employment records are tracked by the state are only for industries available to receive unemployment claims. Some smaller industries are not tracked in the data set.

\section{GIS METHODS}

- Spatial join

\section{GIS STEPS}

* The methods for calculating this variable are the same across all agencies.

1. Add "Employment" and "Stop Buffer" layers into ArcMap

2. Spatial join the "Employment" layer with the "Stop Buffer" layer

- Choose buffer layer as Target Feature

- Choose employment data as Join Feature

- Join Operation choose "Join One-To-One" 
- At field list, right click the field have employment number, and choose merge rule of Sum

3. "Stop Buffer" layer will now contain an attribute field with "Employment" layer data 


\section{HEADWAY}

\section{CONCEPT}

The idea behind Headway is to measure the level of service available at each stop.

\section{CALCULATION}

Frequency is calculated by total run time divided by total buses in a typical day for each route to arrive at an average frequency.

\section{DISCUSSION}

Headways are not always spread out evenly through out a service day. Just subtracting first and last bus of the day for total service time divided by the number of busses to get average headway is less accurate if a bus only operates a couple hours in the morning and a couple in the evening. In the TriMet trips data, there were six routes that had a problem of excessive headways, indicating a potential gap of service during the day. Long headways demanded a closer look to see if there was this type of "donut" service. The best of all possible headways throughout the day was used.

The differences in trips data reporting necessitated a unique method of calculating headways for each agency.

\section{Data Sources}

- LTD- Bus Stops, Trips Data

- TriMet- Bus Stops, Trips Data

- RVTD- Bus Stops, Bus Routes, and Printed Schedules

\section{Preprocessing}

The trips data from LTD and TriMet contained raw trips data, disaggregated by stop, route, direction, and stop. The data is aggregated by the route and direction fields, and the beginning times subtracted between trip origins to determine the frequency of trips. RVTD using hand count data necessitated using printed time tables to obtain headway times for each route.

\section{Caveats}

Where a stop is served by multiple routes, the shortest of all possible headways was used.

\section{GIS METHODS}

- None

- MS Excel

\section{STEPS}

TriMet 
0. Open the "Trips Data” in spss, put "bus route ID” into break variable, and put "trip end time" and "trip start time” into the Summaries of Variables

a. Click Function to choose Maximum for trip end time and Minimum for trip start time

b. Click the "Number of cases" box

1. Under "Save" box, choose "Create a new dataset....", give a name for the new dataset

2. The new dataset will include information about maximum trip end time and minimum trip start time for each bus route/ N_Break is the number of buses run at that day

3. Correct the bias of total run time. The operating time for several bus routes have huge time gaps between morning and afternoon, we therefore deduct these gaps from their total run time by checking the operating time of each bus route.

4. Headway can be calculated by dividing the total run time by number of buses run at that day.

\section{LTD}

1. Open the "Trips Data" in spss, choose a typical weekday, put "bus route ID" and "rte-dir" into break variable, and put "date_and_time" into the Summaries of Variables twice

2. Click Function to choose Maximum and Minimum for "date_and_time" respectively

3. Under "Save" box, choose "Create a new dataset....", give a name for the new dataset (Dataset A)

4. The new dataset will include information about maximum and minimum trip time for each bus route at both direction, and total time can be calculated by deducting the maximum by minimum trip time for each bus route

5. In original dataset, put "bus route ID" and "rte-dir" and "Stop number"into break variable, and Click the "Number of cases" box

6. Under "Save" box, choose "Create a new dataset....", give a name for the new dataset (Dataset B)

7. In this new dataset, it includes information about the number of bus passing at each stop for each bus route and direction

8. Aggregate this new dataset based on "bus route ID" and "rte-dir", and put "N_Break" into the Summaries of Variables twice, and Click Function to choose Maximum for "N_Break” 
9. The new aggregate dataset (Dataset $\mathrm{C}$ ) will have a new variable “N_Break_max", which is the number of bus routes operating at that day

10. Combine Dataset $A$ and Dataset $C$ will get the total operating time and total number of buses operating

11. Correct the bias of total run time. The operating time for several bus routes have huge time gaps between morning and afternoon, we therefore deduct these gaps from their total run time by checking the operating time of each bus route

12. Headway can be calculated by dividing the total run time by number of buses run at that day

\section{RVTD}

1. Create blank spreadsheet in Excel

2. For each route enter Headway and Hours of Operation from printed schedules and save as "Headway"

3. Load "Bus Routes" and "Bus Stops" layers, as well as the "Headway" table into ArcMap

4. Join "Headway" table to "Bus Routes" layer by Route ID

5. Select by Attributes in "Bus Routes" where "Headway =60"

6. Buffer "Bus Stops” by 60 feet (enough for buffer to overlap Route Layer), save as "Stop Service"

7. Select by location where "Stop Service" intersects "Bus Routes"

a. Click "Use Selected Features" and apply

8. Open "Stop Service" attribute table and display selected

9. Add Field for Headway

10. Open the Field Calculator for Headway

11. Set "Headway = 60" and apply

12. Repeat process for each remaining headways (45 \& 30)

*Working down from longest headway results in shortest time for stops served by multiple routes

13. Export as "Stops Headway" 


\section{GENDER}

\section{CONCEPT}

The idea behind this measure is to determine the demographic make up surrounding each stop by measuring gender.

\section{CALCULATION}

Gender is calculated as the ratio of female population divided by total population within each stop buffer area.

\section{DISCUSSION}

\section{Data Sources}

- US Census-ACS 2004-2009 5 years estimation, block groups level

\section{Preprocessing}

Extract data for study area from Census database with the "Summary File Data Retrieval Tool”

\section{Caveats}

Block group level data can have significant margin of errors for some places and indicators because of the small sampling. We need to be cautious when using the data.

\section{GIS METHODS}

- Intersect

- Calculate area for intersecting features

- Aggregate area by buffer ID

\section{GIS STEPS}

1. Add "Block Group” and "Stop Buffer” layers into ArcMap

2. Intersecting ACS block group data with buffer layer

3. Add new field on the new intersecting features, name the new field as "area2", right click the new field and select "calculate Geometry", calculate area

4. Calculate the ratio of "area2" over area of buffer, and then got the ratio of area

5. Calculate the female population and total population based on the ratio of area

6. Aggregate female population by stop ID

7. Calculate the ratio of female population for each buffer 


\section{CONCEPT}

The concept is to measure the average household income of the stop area.

\section{CALCULATION}

ACS block group data for income is intersected with stop area buffer.

\section{DISCUSSION}

\section{Data Sources}

- US Census-ACS 2004-2009 5 years estimation, block groups level

\section{Preprocessing}

Extract data for study area from Census database with the "Summary File Data Retrieval Tool”

\section{Caveats}

Block group level data can have significant margin of errors for some places and indicators because of the small sampling. We need to be cautious when using the data.

\section{GIS METHODS ${ }^{1}$}

- Intersect

- Calculate area for intersecting features

- Aggregate area by buffer ID

\section{GIS STEPS}

1. Add ACS block group layer and buffer layer

2. Intersecting ACS block group data with buffer layer

3. Income in each intersecting area is then calculated

4. Aggregated to the stops based on location ID

5. Calculating the mean of income in each intersecting area

\footnotetext{
${ }^{1}$ Source: Minnesota-Irvine Protocols
} 


\section{INTERSECTIONS}

\section{CONCEPT}

The concept behind this measurement is to determine the design and accessibility for each stop based upon the street network surrounding the stop. Locations with a wellconnected street grid will have a greater number of intersections than locations with a less connected street network, decreasing pedestrian and biking accessibility.

\section{CALCULATION}

Count of all street network intersections within the stop buffer area.

\section{DISCUSSION}

\section{Data Sources}

- Jackson County- Streets

- LCOG- Streets

- Metro- Streets

\section{GIS METHODS ${ }^{2}$}

- Calculate Fnode Tnode

- Spatial join

\section{GIS STEPS}

1. Add "Streets" layer and buffer layer into ArcMap

2. Using ArcMap, install the Calculate Fnode Tnode script following the instructions included within the file

3. Create a point file (layer) that will eventually contain the output of the intersection node procedure

4. Run the Calculate Fnode Tnode tool

5. When prompted, select "Streets" as polyline layer and the new point layer as the point layer

6. Select 0 as the beginning ID number for the nodes

7. After the procedure concludes, your Point Layer will now contain points created from the nodes of the Street Layer. The numbers in Valence field represent the number of roads that converge to create the node (e.g., a valence of 1 means the node is a dead end or cul-de-sac; a Valence of 3 indicates a three-way intersection, etc.)

8. Spatial join the Point Layer into the buffer layer

9. Sum of points with valence of 3 or more for each buffer.

\footnotetext{
${ }^{2}$ Source Minnesota/Irvine
} 


\section{INTERSECTION/NODE RATIO}

\section{CONCEPT}

The concept of this measurement is to determine the pedestrian accessibility for each stop, by determining the connectivity of the street network within each stop buffer area.

\section{CALCULATION}

Count of the number of intersection with three or four way directions divided by the number of cul-de-sacs within each stop buffer area.

\section{DISCUSSION}

\section{Data Sources}

- Jackson County- Streets

- LCOG- Streets

- Metro- Streets

\section{GIS METHODS ${ }^{3}$}

- Fnode Tnode

- Spatial join

\section{GIS STEPS}

1. Add "Streets" layer and buffer layer into ArcMap

2. Using ArcMap, install the Calculate Fnode Tnode script following the instructions included within the file

3. Create a point file (layer) that will eventually contain the output of the intersection node procedure

4. Run the Calculate Fnode Tnode tool

5. When prompted, select Street as polyline layer and the new point layer as your point layer

6. Select 0 as the beginning ID number for the nodes

7. After the procedure concludes, your Point Layer will now contain points created from the nodes of the Street Layer. The numbers in the Valence field represent the number of roads that converge to create the node (e.g., a valence of 1 means the node is a dead end or cul-de-sac; a Valence of 3 indicates a three-way intersection, etc.)

8. Spatial join the Point Layer into the buffer layer

9. Sum of points with valence of 1 and $3+$ for each buffer

10 . Nodes ratio are calculated by dividing the \# points with valence of valence $3+$ with valence of 1

\footnotetext{
${ }^{3}$ Source: Minnesota-Irvine Protocols
} 


\title{
LAND USE DIVERSITY
}

\section{CONCEPT}

Landuse dissimilarity as defined by Song and Rodriguez (2005). The mix of various land uses within a buffered area. Entropy is measured on a scale of $0-1$.

\section{CALCULATION}

Based on methodology from the Minnesota Walking Study GIS protocols by Anne Forsyth.

\section{DISCUSSION}

\author{
Data Sources \\ - Jackson County- Landuse \\ - LCOG-Landuse \\ - Metro-Landuse
}

\section{Preprocessing}

\section{Caveats}

Different classification system for land use between TriMet and LTD. Re-classify the LTD data is needed to make data consistency.

\section{GIS METHODS}

- Intersect

\section{GIS STEPS}

1. Area of each type of land use are calculated for each buffer area

2. Entropy for each buffer are calculated by employing the formula: Entropy $\{[$ [ $\mathrm{p})(\ln \mathrm{p})]\} /(\ln \mathrm{k}) ; \mathrm{p}$ is the proportion of each type of land use within the buffer area, $\mathrm{k}$ is the number of land use types. 


\section{LIGHT RAIL (LRT)}

\section{CONCEPT}

The concept of this measurement is to categorize the level of service at the stop level, represented here by the availability of high capacity transit. A greater number of light rail stops is expected to have an increase in transit ridership.

\section{CALCULATION}

Sum of light rail stops within the stop buffer area.

\section{DISCUSSION}

\section{Data Sources}

- $\quad$ TriMet- LRT Stops

\section{GIS METHODS}

- Spatial Join

- Table Join

\section{GIS STEPS}

\section{TriMet}

1. Spatially Join stop buffers to LRT stops layer to generate new polygon with count field

2. Add new field call "LRT" set to equal the "Count" field

3. Join new LRT layer table to stops layer by attribute table 


\section{MULTI-FAMILY HOUSING}

\section{CONCEPT}

The basic idea of this measure is to capture trip origins from areas containing multifamily housing units.

\section{CALCULATION}

Sum the multi-family land use area within each buffer.

\section{DISCUSSION}

\section{Data Sources}

- Metro-Multi-Family Housing

\section{Caveats}

Multi-family layer for LTD need to be aggregated.

\section{GIS METHODS}

- Intersect

\section{GIS STEPS}

1. Add taxlots and buffer layers into ArcMap

2. Definition Query, choose multi-family type based on land use code

3. Export the multi-family land use layer

4. Intersect the multi-family land use layer with buffer layer

5. Add new field named "Area2" for the new intersecting layer, and click Calculate Geometry to calculate the area

6. Aggregate "Area2" by bus stop ID

7. Ratio of multi-family land use is calculated by dividing the Area2 by total area of buffer 


\section{PARKS}

\section{CONCEPT}

The idea of this measure is to capture potential trip destinations and land use. Parks are listed as a "Pedestrian Magnet" by various sources. Due to the large size of parks, they did not lend themselves to the same type of methodology uses for the other pedestrian magnets, which are based upon the centroid of each tax lot.

\section{CALCULATION}

The calculation for parks is the sum of all park polygons that intersect each stop buffer.

\section{DISCUSSION}

\section{Data Sources}

- Jackson County-Parks

- LCOG- Parks

- Metro- Parks

\section{Caveats}

Some parks have multiple files for admin buildings, pools, etc. Count may be skewed toward parks with multiple facilities in database

\section{GIS METHODS}

- Select by Attributes/Export

- Spatial Join

\section{GIS STEPS}

\section{TriMet:}

1. Select by attributes where "CUSTODIAN" LIKE '\%City\%'

2. Export as "City Parks"

3. Join stop buffer to "Parks" layer based upon spatial location (intersects a polygon)

4. Export as new layer "Park" with count field of parks per buffer area

\section{LTD:}

1. Join stop buffer to "Parks" layer based upon spatial location (intersects a polygon)

2. Export as new layer "Park" with count field of parks per buffer area

\section{RVTD:}

1. Add "Jackson County Open Space" and "Stop Buffers" layers into ArcMap

2. Select by attributes in "Open Space" where "Parktype" = "Park"

3. Export as "Parks"

4. Spatial join "Stop Buffers" to "Parks" layer based upon spatial location (intersects a polygon)

5. Export as new layer "Park" with count field = to sum of parks per buffer area 
b. Caveat: Some parks have multiple polygons or separate polygons for admin buildings, pools, etc. Count may be skewed toward parks with multiple polygons 


\section{PARK AND RIDE}

\section{CONCEPT}

The concept for this measure is to capture trip origins and destinations, and transit facilities. Park and ride locations are points of entry into the transit system for commuters with access to an automobile.

\section{CALCULATION}

The calculation for this measure is the sum of park and ride locations within each stop buffer.

\section{DISCUSSION}

To further fine tune the effects of park and ride locations on transit ridership, park and ride stops are defined in two categories; park and rides with bus service only, and park and rides with both bus and either LRT or BRT stops.

\section{Data Sources}

- LTD- Park and Ride

- $\quad$ RVTD- Park and Ride

- TriMet- Park and Ride

\section{Preprocessing}

Clean data set by removing temporary and overflow lots

\section{Caveats}

A buffer of 500 feet was used to select transit stops around park and ride point layers. The distance was decided upon after exploration of the average distance between the closest stops to park and rides.

\section{GIS METHODS}

- Spatial Join

- Table Join

\section{GIS STEPS}

\section{LTD:}

1. Remove BRT stops from stops layer by selecting by location where "stops are within 20' of a BRT stop

2. Switch selection

3. Export selection named Bus stops only

4. Circular buffer PnRs by 500' (determined by exploring PnRs distance from nearest stops

5. Manually inspect buffers and move to include stops only adjacent to PnR

6. Select by location where "Bus stops are within PnR Buffer Area" 


\section{TriMet:}

1. Add "Park and Ride", "Bus", and "LRT" layers into ArcMap

2. Buffer "Park and Ride” by 500'

3. Manually inspect each buffer and adjust if necessary to select only stops at transit centers or imediately adjacent to "Park and Ride"

4. To determine "Park and Ride"with "Bus and LRT":

a. Select by location where "PnR buffer contains Bus Stops"

b. Select by location using “Add to selection” where “"Park and Ride”buffer contains "LRT Stops"

c. Export as "PnR-Bus and LRT"

5. To determine park and rides with "Bus only"

a. Select by location where "PnR buffer contains Bus Stops"

b. Select by location using "Remove from selection” where " PnR buffer contains LRT Stops”

c. Export as "PnR-Bus only buffer"

6. Utilizing exported buffers, select by location where "PnR in within PnR buffer"

7. Export the selection as PnR Bus only/Bus and LRT

\section{RVTD:}

1. Add "Park and Ride" and "Bus Stops" layers into ArcMap

2. Buffer "Park and Ride” layer by 500"

3. Save as "PnR Buffer"

4. Select by location "Bus Stops" that are within "PnR Buffer"

a. Manually add stops that aren't within buffer, but are within 800' of buffer (Talent PnR doesn't have any stops inside buffer)

5. Export selected features as "Park and Ride Stops" 


\section{PEDESTRIAN DESTINATIONS}

\section{CONCEPT}

Pedestrian Magnets are defined by LEED "Development Density \& Community Connectivity” (pg 36). Pedestrian Magnets are used to model potential origins and areas more conducive to pedestrian access.

\section{CALCULATION}

The calculation is the sum of all Pedestrian Magnets within the stop buffer area.

\section{DISCUSSION}

\section{Data Sources}

- LCOG- Employment

- Metro- Employment

- Oregon Employment Department- Employment

\section{Preprocessing}

The Employment layer does not contain a good NAICS code for public libraries. Metro's RLIS database contains a public library layer that was merged with the employment layer to complete the Pedestrian Magnets list. LCOG does not maintain such a layer, so for Lane County a search of public libraries using Google Maps produced a KML layer, which is imported and merged to complete the Pedestrian Magnets list.

\section{GIS METHODS}

- Select by attributes/ Export

- Import KML

- Project

- Merge

\section{GIS STEPS}

TriMet:

1. Select pedestrian magnet locations from NAICS field in employment layer

2. Export as NAICS_PedMags

Merge Library layer and PedMags into a single file called "PedMags"

\section{LTD:}

1. Select pedestrian magnet locations from NAICS field in employment layer

2. Export as NAICS_PedMags

3. Geocode Library locations

4. Export KML file from Google Maps

5. Import and convert to Shapefile in GIS 
6. Project from WGS84 to NAD 83

7. Export as "Libraries"

8. Merge "Libraries" and PedMags into a single file called "PedMags"

\section{RVTD:}

1. Select pedestrian magnet locations from NAICS field in employment layer

2. Export as NAICS_PedMags

Add Library Layer into ArcMap

Merge "Libraries" and PedMags into a single file called "PedMags"

\begin{tabular}{ll}
\hline Minnesota/Irvine: & NAICS \\
\hline Convenience/small grocery store & 445120 \\
Gas station w/ convenience store & 447110 \\
Supermarket & 445110 \\
Hardware store & 444130 \\
Fruit/vegetable market & 445230 \\
Laundry/dry cleaners & 812320 \\
Clothing store & 448120 \\
Post office & 491110 \\
Elementary school & 611110 \\
Other schools & $611210,611310,611410$ \\
Book store & 451211,453310 \\
Fast food restaurant & 722211 \\
Coffee place & 722213 \\
Bank/credit union & 522110 \\
Non-fast food restaurant & 722110,722211 \\
Video store & 532230 \\
Pharmacy/drug store & 446110 \\
Salon/barber shop & 812112 \\
Recreation center & 713940,624110 \\
*Day Care & 624410 \\
*Place of worship & 813110 \\
*Senior Care Facility & 624120 \\
& $621111,621112,621210$, \\
*Medical/Dental & $621310,621320,621330$, \\
& 621391 \\
**Library & Metro/LCOG \\
**Park & Metro/LCOG \\
*Transit stop/station & TriMet/LTD \\
\hline *Added from LEEDS & \\
** Geocoded from other sources & \\
\end{tabular}




\section{POPULATION}

\section{Concept}

Total population lived in each buffer area.

\section{CALCULATION}

ACS block group data intersect with stop buffer layer.

\section{DISCUSSION}

\section{Data Sources}

- US Census-ACS 2004-2009 5 years estimation, block groups level

\section{Preprocessing}

Extract data for study area from Census database with the "Summary File Data Retrieval Tool”

\section{Caveats}

Block group level data can have significant margin of errors for some places and indicators because of the small sampling. Caution is recommended when using this data.

\section{GIS METHODS}

- Intersect

- Calculate area for intersecting features

- Aggregate area by buffer ID

\section{GIS STEPS}

1. Add ACS block group layer and buffer layer

2. Intersecting ACS block group data with buffer layer

3. Add new field on the new intersecting features, name the new field as "area2", right click the new field and select "calculate Geometry", calculate area

4. Calculate the ratio of "area2" over area of buffer, and then got the ratio of area

5. Calculate the total population based on the ratio of area for each buffer

6. Aggregate Total population by stop ID 


\section{POPULATION DENSITY}

\section{CONCEPT}

Population density is measured within each stop buffer area measured as net density excluding water and public lands.

\section{CALCULATION}

Measures population divided by land area using a dissymmetric correction technique to determine what portion of each buffer is inhabited.

\section{DISCUSSION}

\section{Data Sources}

- $\quad$ US Census-ACS 2004-2009 5 years estimation, block groups level

\section{Caveats}

Density measurements can be done in a variety of ways. Units of measurement can either be in population or housing unit density, and the land area calculated can be in either net or gross density. Gross density removes the land areas occupied by developable land, removing features such as water and parks. Gross density calculates the total amount of land per unit area regardless of potential uses, resulting in lower densities.

We chose to measure population density. Further, we use a dysemetric technique to proportionally split the population in each census block group to the percentage of overlap in the stop buffer area.

\section{GIS METHODS}

- Dysemetric Correction

- Intersect

\section{GIS STEPS}

1. Add ACS block group layer, water layer and buffer layer

2. Use "Erase tool" to create ACS block layer with water feature removed, and buffer layer with water feature removed

3. Intersecting ACS block group data with buffer layer

4. Add new field on the new intersecting features, name the new field as "area2”, right click the new field and select "calculate Geometry", calculate area 
5. Calculate the ratio of "area2" over area of buffer, and then got the ratio of area

6. Calculate the total population based on the ratio of area for each buffer

7. Aggregate Total population by stop ID

8. Calculate the area for buffer with water feature removed

9. Population density can be calculated by dividing the total population in the buffer by buffer area with water feature removed 


\section{Concept}

Total households with annual income under the poverty level lived in each buffer area.

\section{CALCULATION}

ACS block group data intersect with stop buffer layer.

\section{DISCUSSION}

\section{Data Sources}

- US Census-ACS 2004-2009 5 years estimation, block groups level

\section{Preprocessing}

Extract data for study area from Census database with the "Summary File Data

Retrieval Tool”

\section{Caveats}

Block group level data can have significant margin of errors for some places and indicators because of the small sampling. We need to be cautious when using the data.

\section{GIS METHODS}

- Intersect

- Calculate area for intersecting features

- Aggregate area by buffer ID

\section{GIS STEPS}

1. Add ACS block group layer and buffer layer into ArcMap;

2. Intersecting ACS block group data with buffer layer

3. Add new field on the new intersecting features, name the new field as "Area2", right click the new field and select "calculate Geometry", calculate area

4. Calculate the ratio of "Area2" over area of buffer, and then got the ratio of area by dividing the Area2 by total area of buffer

5. Calculate the households under poverty level based on the ratio of area

6. Aggregate Households under poverty level by stop ID 


\section{SINGLE FAMILY HOUSING}

\section{CONCEPT}

The basic idea of this measure is to capture trip origins from areas containing singlefamily housing units.

\section{CALCULATION}

Sum the single-family land use area within each buffer.

\section{DISCUSSION}

\section{Data Sources}

- Jackson County- Taxlots

- LCOG- Taxlots

- Metro- Taxlots

\section{Caveats}

Single-family layer for Lane County need to be aggregated.

\section{GIS METHODS}

- Intersect

\section{GIS STEPS}

1. Add taxlots and buffer layers into ArcMap

2. Definition Query, choose single-family type based on land use code

3. Export the single-family land use layer

4. Intersect the single-family land use layer with buffer layer

5. Add new field named "Area2" for the new intersecting layer, and click Calculate Geometry to calculate the area

6. Aggregate "Area2" by bus stop ID

7. Ratio of single-family land use is calculated by dividing the Area2 by total area of buffer 


\section{TRANSIT CENTER}

\section{CONCEPT}

This measure identifies transit stops that are located at transit centers.

\section{CALCULATION}

The calculation consists of a binary measurement identifying whether or not a stop is located at a transit center.

\section{DISCUSSION}

Identifying transit stops that are located at transit centers is used to control for the extra ridership expected to occur at these stops.

\section{Data Sources}

- LTD- Bus Stops

- RVTD- Bus Stops

- $\quad$ TriMet- Bus Stops

\section{Preprocessing}

LTD has an attribute field indicating stops that are located at "Transit Centers". However, bus rapid transit stops are also classified as “Transit Centers” but EmX stops are also listed as transit centers and must be removed from the layer before processing. The process of selecting transit center stops is shown below.

TriMet has stops located at transit center identified in the "Name" field of the attributes of bus stops. The name of transit centers were selected using a wildcard search and exported as a "Transit Center Stops" layer.

\section{GIS METHODS}

- Select by Attributes

- Table Join

\section{GIS STEPS}

\section{TriMet:}

1. Add "Bus Stop" and Buffer layers into ArcMap

2. Select by attributes from stops layer, "Name $=* *$ Transit Center"

3. Export selected stops as "Transit Center" stops and add to map

4. Table Join the "Transit Center Stops" with the "Bus Stop" layer and create a field called "Transit Center" 


\section{LTD:}

1. Add "Bus Stop" and Buffer layers into ArcMap

2. Select by attributes from stops layer, "Stop Zone = Transit Center"

3. Manually deselect EmX stations from selection

4. Export selected as "Transit Center Stops" and add to map

5. Table Join the "Transit Center Stops" with the "Bus Stop" layer and create a field called "Transit Center"

\section{RVTD:}

1. Select by attributes from "Stops Layer", where "Stop ID = 001"(Front Street Station was previously identified as stop_id 001.

2. Export as Transit Center Stops

3. Add field "Transit Center"

4. Set default to 0

5. Using Editor, enter " 1 " in "Stop ID 001", 1 for transit center yes

* There is only one transit station in RVTD's system, so the methods of selection are simplified. 


\section{TRANSFER STOPS}

\section{CONCEPT}

The concept of this measure is to capture transfer opportunities between routes within each stop buffer area, stops where two or more routes are available.

\section{CALCULATION}

The calculation consists of a binary measurement identifying whether or not route transfer opportunities exist at each transit stop.

\section{DISCUSSION}

The presence of transfer opportunities is expected to increase ridership at transit stops.

\section{Data Sources \\ - LTD- Bus Stops \\ - RVTD- Bus Stops \\ - TriMet- Bus Stops}

\section{Preprocessing}

Transfer stops identifying transfer opportunities were not available from the agencies within the study, requiring the data to be created using existing stop and route GIS layers. The team defined a transfer stop as stops where two or more routes pass. The differences between data formats kept by the agencies required agency specific methods outlined below.

\section{LTD:}

Bus Stops Layer consists of a one to one point representation of bus stops, where each point represents a bus stop location that serves one or more routes. The layer does not show route affiliations. To identify stops where two or more buses (transfer opportunities) exist, the corresponding bus routes layer was used. The line file consists of a number of poly-line segments that was generated from the underlying street network; each segment has a Route ID. The feature was dissolved by Route ID to produce a feature in which each line segment represented the entire route.

The stops were buffered by $60 \mathrm{ft}$, enough to reach the street centerline, and spatially joined to the routes lines layer in order to produce a field containing a count of routes passing through the buffer area. Stops were then selected where "Count $=>2$ ", two routes serving a stop indicates an opportunity to transfer.

\section{TriMet:}

The Bus Stops Layer for TriMet consists of a many to one point representation for each stop, where multiple points at each location identifies each route serving a stop. To identify stops served by two or more routes, the Bus Stops Layer is copied, so 
that there were two identical sets of stops. A Table Join was then performed to generate a count field that indicates the number of coincident points at each stop. Stops were then selected where "Count $=>2$ ", two routes serving a stop indicates an opportunity to transfer.

Transit centers and stops near LRT stations presented a problem in having the points spread out for each route in the geographic location of each bus bay. To account for this, stops were selected by location where "Bus Stops $=<150$ ' of Transit Center, and Bus Stops $=<50$ ' of LRT Stop”. Each location was manually inspected for accuracy, requiring some additions and subtractions to the selection were made. This selection was added to the selection of two or more coincident stops outlined above to identify transfer opportunities.

\section{RVTD:}

RVTD uses a database scheme much like LTD where a single point represents each stop and many routes may be associated with any single point. Unlike LTD, each bus stop is contains an attribute indicating which route serves each stop. Bus stops are attributed with a Stop ID, which like LTD is also a Location ID.

\section{Caveats}

At transit centers in the TriMet data where inbound and outbound occur at the same stop location, there may be an inflated transfer count (Example: Location ID \#1 = Rte 37-in, Rte 37). The team felt that this wasn't enough to rule out the methods.

\section{GIS METHODS}

- Buffer

- Dissolve

- Spatial Join

- Select by Attributes

\section{GIS STEPS}

TriMet:

1. Add Bus Stops Layer into ArcMap

2. Copy Bus Stops Layer

3. Paste Layer so there are now two copies of Bus Stops

4. Join Tables to obtain a count field indicating number of coincident points (routes served at each location)

5. Generate model to select stops by attributes of count field and proximity to transit centers and LRT stops

6. Select bus stops by: Count $=>2$

7. Select bus stops $=<150$ ' of transit center

8. Select bus stops $=<50$ ' of LRT stop

9. Manually inspect each transit center location and add or remove stops to selection 


\section{LTD:}

1. Select transfer stops by route line

2. Dissolve routes shapefile by "Route" field

3. Buffer Stops by 60 feet

4. Spatial Join buffer to Dissolved route layer to generate Count field base upon number of different routes that are intersected by buffer

5. Join buffers to stops

6. Select stops with count field that are $=$ or $>2$

7. Export stops as Transfer stops

\section{RVTD:}

1. Stop layer includes route identifier at each stop, but is not accurate

2. Dissolve route layer by "Route" to retrieve single polyline per each route

3. The layer file received is an updated 2009 file that includes several routes not in operation in 2008, so it is necessary to remove these routes from the layer first.

4. Select Routes: 1,2,10,30,40,60 and export as “2008 RVTD Routes”

5. Using Editor, truncate route names to "Route \#” (example, Route 60 White City, and Route 60 White City Non-Peak Service)

6. Dissolve routes layer by "Route" field to obtain a single polyline for each route

7. Export as "RVTD 2008 Routes"

8. Buffer Stops by 60 feet

a. Manually move buffers that are farther than 60 feet from Route layer, to overlap layer

9. Spatially Join "Buffer” layer to "RVTD 2008 Routes" and generate Count field based upon number of different routes that intersect each buffer

10. Join "Buffer" layer to "Stops" layer

11. Select stops with a count field that are $=$ or $>2$ (more than 1 route available)

12. Export stops as "Transfer Stops" 


\section{WHITE/RACE}

\section{CONCEPT}

Ratio of white population within each buffer area.

\section{CALCULATION}

ACS block group data intersect with stop buffer layer.

\section{DISCUSSION}

\section{Data Sources}

- ACS 2004-2009 5 years estimation, at the block group level.

\section{Preprocessing}

Extract data for study area from Census database with the "Summary File Data

Retrieval Tool”

\section{Caveats}

Block group level data can have significant margin of errors for some places and indicators because of the small sampling. We need to be cautious when using the data.

\section{GIS METHODS}

- Intersect

- Calculate area for intersecting features

- Aggregate area by buffer ID

\section{GIS STEPS}

1. Add ACS block group layer and buffer layer into ArcMap

2. Intersecting ACS block group data with buffer layer

3. Add new field on the new intersecting features, name the new field as “Area2”, right click the new field and select "calculate Geometry”, calculate area

4. Calculate the ratio of "Area2" over area of buffer, and then got the ratio of area by dividing the Area2 by total area of buffer

5. Calculate the White population based on the ratio of area

6. Aggregate White population by stop ID

7. Ratio of white population is calculated for each buffer area by dividing the White population by Total population 



\section{GOTREC \\ AND EDUCATION CONSORTIUM}

P.O. Box 751

Portland, OR 97207

OTREC is dedicated to stimulating and conducting collaborative multi-disciplinary research on multi-modal surface transportation issues, educating a diverse array of current practitioners and future leaders in the transportation field, and encouraging implementation of relevant research results. 